\title{
Experimental Investigations on the Frictional Resistance of Planks and Ship-models.
}

\author{
By Professor Yuzuru Hiraga, Constructor Vice-admiral (Ret.), Member.
}

[Read at the Autumn Meetings of the Society of Naval Architects, Japan, November 11, 1934]

\section{Introduction.}

For many years we have followd the Froude law for the frictional resistance of planks, ship-models and ships. It is true that in recent years a marked advance has been made by the establishment of new theories and formulae by several authorities on the subject from their theoretical and experimental results, however it may be said that they do not establish any definite unity for practical applications. The reason appears to be principally due to the difficulty, even with planks, of carrying out a number of experiments on various conditions of different water temperatures and different immersions of planks in an experimental Tank, and the difficulty of carrying out experiments on actual ships. The suggestion of the "Skin Friction Committee's Report"(1) was to extend the tank experiment by the towing experiment of long planks and a destroyer.

For the Imperial Japanese Navy, a new Tank, one of the latest models, to replace one destroyed by the great earthquake and fire in 1923, was in course of construction in the precincts of the Naval Technical Research Department. However, as it would take some time before its completion, an emergency measure was taken, and in 1925 a small Tank (6 feet wide, 4 feet deep and 100 feet long-afterwards extended to 150 feet) was constructed, and resistance experiments were started. The results of this small Tank were most satisfactory and its usefulness was fully confirmed.(2) It was just then that the author was deeply impressed with the "Skin Friction Committee's Report" and was contemplating to take up a study in this direction and to make the utilization of the small Tank for the ship-model assured. On account of the smallness of the Tank, the time and the expense for experiments were not great, the change of draughts could be easily adjusted by the up and down change of the water surface, the temperature of the tank water could be inexpensively governed, and fresh water and sea-water could be quickly interchanged. Taking all these advantages, during

(1) Trans. I.N.A., 1925.

(2) Hiraga, "A Place for a small Experimental Tank," Jour. Soc. N.A., Japan, Vol. 40, 1927. 
1925-1931, the author, assisted by the tank staff, carried out a number of experiments on planks, plates, and ship-models, and further, when necessity called, similar experiments were entrusted to the Mitsubishi Tank to check the small-tank results. Thus a general idea of the frictional resistance of planks and ship-models was fairly established. Thereupon, in 1928 a plank-ship for which the residuary resistance may be negligibly small, having a length of 77 feet, a width of 6.3 inches only and a displacement of 3.4 tons, was made and towing experiments were carried out in a quiet harbour, with speeds up to 16.2 knots (Reynolds' number $227 \times 10^{6}$ ) to check the small-tank results. Further, our navy having observed the importance of carrying out towing experiments on a destroyer of 232 feet in length and 368 tons in displacement, a special Committee was formed in 1928, and a series of experiments were carried out up to a speed of 21 knots (Reynolds' number $804 \times 10^{6}$ ), and in the following year, 1929, another series of experiments were made up to a speed of 26.3 knots (Reynolds' number 1,009 $\left.\times 10^{6}\right)$. Apart from this Committee, a tug-boat of 115 feet in length and 297 tons in displacement was also subjected to the tests up to a speed of 6.8 knots (Reynolds' number $\left.109 \times 16^{6}\right)$.

The results of these tank tests and of the towing tests of the plank-ship, the destroyer and the tug-boat confirmed not only their consistency with each other, but a conformity when applied to the result of the "Greyhound" experiment.

The author has collected all the results obtained from the experiments and prepared two papers, of which this forms the first paper. ${ }^{(3)}$ The present paper is divided into two parts: Part I-Effect of Temperature and Sea-water on the Frictional Resistance of Planks and Ship-models, and Frictional Resistance of Planks, and Part II -Frictional Resistance of Longer and Shorter Planks, and Ship-models.

\section{Part I. Effect of Temperature and Sea-water on the Frictional Resistance} of Planks and Ship-models, and Frictional Resistance of Planks.

$\S 1$. The frictional resistance $R_{f}$ of similar bodies (the surface area $S$ and the length $L$ ) moving through a fluid (the density $\rho$, and the kinematic viscosity $\nu$ ) with a velocity $V$ may be expressed by, if it be a function of the above quantities only,

$$
R_{f}=\rho S V^{2} f(V I / / \nu)
$$

or by its more practical form, $\quad R_{f}=c \rho S V^{2}(V L / \nu)^{N}$

(3) The second paper "Experimental Investigations on the Resistance of Long Planks and Ships" was read at the Summer Meetings (The International Tank Conference) of the Seventy-fifth Session of the Institution of Naval Architects, July 11, 1934. 


$$
R_{f}=\rho S V^{2}\left\{a+b(V L / \nu)^{M}\right\}
$$

where $a, b, c, N$ and $M$ are constants depending on the nature of the surface. These expressions are now generally accepted, but to study this form by experiments, there are obviously many difficulties brought out requiring a perfect geometrical similarity, etc.. With planks of similar dimensions, it is almost impossible to have a geometrically similar nature of surface. Again when $L, V$, or $V L / \nu$ is very small, the results of experiments may be somewhat doubtful due to the occurrence of the instability of the flow, or the presence of the critical velocity, etc., also the presence of the "edge effect" will further this doubt. On the other hand, if, at a start, one plank of certain dimensions and of a certain nature of surface is taken, and the variation of the resistance due to the change of $\rho$ and $\nu$ by only changing the temperature of the water is observed, and if a series of similar observations are made for various lengths of planks and their relative values are studied, such doubt may be avoided to an utmost degree and may be an easy means of solving the form of the functions.

Lord Rayleigh stated at the end of his memoirs to Fluid Friction on Even Surface. ${ }^{(4)}$ "In a series of experiments designed to determine the form of $F$, there would be advantage in keeping $v$ (and $a$ ) constant, while $\nu$ is varied." ( $F=\rho v^{2} f(a v / \nu)$, where $F$ is the resistane per unit area, $v$ the velocity and $a$ the linear dimension.) Here Lord Rayleigh's $\nu$-variation seems to mean the variation when the fluid is air or water, but actually a great variation in temperature may also have the same meaning.

Now it is well known that the resistance is increased or decreased according to the decrease and increase of the temperature of the water; for instance, for the variation of the frictional resistance per $10^{\circ} \mathrm{F}$. change of temperature at or near $55^{\circ} \mathrm{F}$., it appears to be a general practice in Great Britain and other countries to allow about 3 per cent. for a temperature correction. In spite of the importance of a correct value of this variation to the tank experiment and the trial of actual ships, so far as the author's knowledge serves, no results of systematic experiments have been published. Probably it is due to a quasi-impossibility of adjusting the temperature of a great mass of water in an ordinary experimental Tank, which makes it impossible to examine the temperature effect on the resistance continually and freely.

In the small Tank of our navy, having the water-quantity only 67 tons, the temperature of the water could easily be adjusted by passing steam or putting ice in the water within the range of 100 degrees, between $38^{\circ}$ and $138^{\circ} \mathrm{F}$.. The author took

(4) Scientific Papers, Vol. V, p. 197. 
up the investigations to find out the correct amount of the temperature correction, also the temperature effect on the nature of the frictional resistance. Next, the fresh water in the Tank was changed into sea-water and the sea-water effect was investigated with a view to examining the possibility of application of the determined relations of the resistance with $\rho$ and $\nu$ based on the temperature experiment in fresh water to two kinds of fluid having different values of $\rho$ and $\nu$, i.e., fresh water and sea-water at the same temperature and determining the correct amount of sea-water correction necessary for applying the tank results to an actual ship.

Also finding the importance of the variation of resistance due to the change of immersion for the study of the frictional resistance, a number of planks were experimented with at various immersions by up and down adjustment of the tank-water surface. This has enabled the author to arrive at the ultimate results and at the same time to prove the great merit of small Tanks.

\section{Experimental Apparatus and Methods.}

$\S 2$. The arrangement for the experiments on planks and ship-models in the small Tank is shown in Figs. $1_{a}, 1_{b}, 1_{c}$ and $1_{d}$, Plate $I$. Planks or plates were towed by fixing them on a well-balanced swinging frame carried on knife-edges, great care being taken to have the lower edge of the plank perfectly in a straight line and horizontal. Throughout the experiments, the air resistances for the emerged part of planks and ship-models were not deducted except where otherwise stated. The swinging frame was made for a least possible air-resistance and the air-resistance of the frame was deducted.

Truck speeds were 45 to 800 feet per minute, and the maximum possible error was not more than 0.7 per cent. at the lowest speed and not more than 0.1 per cent. at the highest speed, and the sensibility of the resistance when a plank is fixed to the swinging frame and towed was about $0.0026 \mathrm{lb}$, and for $1 \mathrm{lb}$. of resistance it was not more than $0.006 \mathrm{lb}$., and for $6 \mathrm{lb}$. of resistance not more than $0.013 \mathrm{lb}$. In the case of ship-models the results were ruch better. Throughout the experiments, great care was taken to minimize these possible errors.

In preparing planks or plates, great care was taken for their straightness and smooth surface. The fore and aft ends, and the lower edge of a plank were well tapered out from the parallel sides and finished to a sharp knife-edge at ends and edge. It may be stated here that one of the reasons for giving uniform results throughout the experiments may be attributed to this sharpness of the lower edge. The shape of 
planks, except where otherwise stated, was rectangle. In the case of ship-models and planks intended for basic experiments, a lacquered surface which is more lasting free from temperature was used. When necessary, varnish, paint, paraffin, and bright metal surfaces were also used. In some of the rough-surface experiments a very fine ironpowdered surface was used.

§3. In order to check the results of the small-tank test, (a) 5-foot and (b) 6-foot models of a destroyer, made of wood, having a varnished surface, (c) 4- and 5-foot standard models of a ship, made of metal,having a lacquered surface, and (d) a 14foot plank having a lacquared surface were tested at the small Tank and at the Mitsubishi Tank. The same model was used for the two Tanks, but two planks were used, of which one at the Mitsubishi Tank was made a little thicker than the other. The results obtained at these two Tanks for (b) and (d) are shown in Figs. $1_{e}$ and $1_{f}$, Plate I. It will be observed that in (a) the 5 -foot destroyer, (b) the 6-foot destroyer, (c) the 4- and 5-foot standard models with speeds not more than about 380, 320, 380 and $320 \mathrm{ft}$. per min. respectively, (speed-length ratio 1.7, 1.3, 1.9 and 1.6 respectively), and in the 14-foot planks not more than $300 \mathrm{ft}$. per min., the test results of two Tanks are in perfect conformity with each other, and at higher speeds the small-tank tests indicate somewhat larger resistances. Within the scope of the experiments, the maximum difference of resistance in the ship-models is $2 \frac{1}{2}$ to 4 per cent., and in the planks not more than 1.7 per cent., and the difference diminishes as the speed increases and finally tends to become almost nil. As the results of the two Tanks below the above speeds conform with each other, the accuracy of the two Tanks may be taken as identical. At higher speeds in the case of ship-models, probably the difference may be due to the wall and bottom effect of the small Tank, but in the case of planks, the author is at a loss to attribute the difference.

From these facts, it will be seen that even a small Tank having the width of only 6 feet, if 4- to 6-foot ship-models were used below a certain speed, would give the same results as an ordinary Tank, that in such a Tank there would be a certain amount of the wall and bottom effect at higher speeds according to the size of ship-models, that when a long plank such as 14 feet long is used, a difference begins to appear at a higher speed and its maximum amount is not more than 1.7 per cent., and that these differences tend to diminish at still higher speeds. Therefore, if the wall effect was suitably dealt with, the small-tank results may be taken to be quite as trustworthy as those of large Tanks. The wall effect will be commented on in Appendix IV and the plank results further in $\S 20$, Part II, and also the necessity of considering an existence of critical velocities for ship-models and planks not more than 4 feet in length will be discussed in Appendix I. 
§4. For raising the temperature of the tank water, a 2-inch steam main was led along the tank wall, and eight $1 \frac{1}{4}$-inch portable pipes, each with a nozzle at the end, were branched out, and led in near the tank bottom. The tank water was heated to a uniform temperature by injecting steam from these nozzles, while giving a motion to the water by means of a wave-maker or some suitable stirrers. Finally the water surface was skimmed off carefully to clear off some oily matters. By this means it was easy to raise the temperature at the rate of $5^{\circ} \mathrm{F}$. per hour, and when necessary ice blocks were put into the water, and though it was not so easy as the heating process, it was possible to lower the temperature of the water from $55^{\circ} \mathrm{F}$. down to $41^{\circ} \mathrm{F}$..

Thus it was possible to carry out experiments at any temperature of the water between $38^{\circ}$ and $138^{\circ} \mathrm{F}$.. At higher temperatures, naturally the water temperature tends to come down to the room temperature, but the average time required for an experiment to obtain one resistance to base speed curve is about $1 \frac{1}{2}$ hours, and during this period, the lowering of the water temperature at $100^{\circ} \mathrm{F}$. was not more than $1 \frac{1}{2}^{\circ} \mathrm{F}$. even in winter. At the highest temperature, that is, when the water temperature was $140^{\circ} \mathrm{F}$., and the temperature inside the room was $87^{\circ} \mathrm{F}$., and outside was $60^{\circ} \mathrm{F}$., the lowering of the temperature was about $2 \frac{1}{2}^{\circ} \mathrm{F}$., but in such a case, an extra steaming was given during the experiment, and it was possible to bring the condition to the same as that of $100^{\circ} \mathrm{F}$.. Therefore, the difference of the temperature during the experiment may be generally taken as less than $1 \frac{1}{2}^{\circ} \mathrm{F}$.. The temperature difference of the bottom and surface water was never more than $0.2^{\circ} \mathrm{F}$.. The temperature noted in the test results is the mean of eighteen measurements at six different places and three different times. One complete experiment consisted of a forward journey of low speeds to high speeds and a return journey of high speeds to low speeds.

The lowering of the water temperature naturally causes a change in water volume accompanying the change of water depth in the Tank. This was often measured, and it was found that at high temperatures and during the period between the start and finish of the experiment, i.e. during $1 \frac{1}{2}$ hours, the water level was lowered by 0.01 inch. The draught of planks was reduced by that amount. The immersion of planks used for testing the temperature effect was mostly 6 inches, which corresponds to about 0.2 per cent. error. But a brass plate which was measured in a room of normal temperature, expands when put into water of high temperature, say for a difference of $50^{\circ} \mathrm{F}$., about 0.1 per cent. increase in area, which offsets the aforementioned error to a certain degree, therefore the change of draught and area attributed to these causes was neglected.

Thus the experiments in Part I were made with 4- to 8-foot plates, and 4- to 6-fcot 
ship-models, a speed of 45 to 600 feet per min. and at temperatures $38^{\circ}$ to $138^{\circ} \mathrm{F}$., i.e. the kinematic viscosity $(1.72$ to 0.53$) \times 10^{-5}$ in $\mathrm{ft}^{2} \times \mathrm{sec}^{-1}$, and the temperature effect was investigated.

For sea-water experiments, the clean sea-water taken from the deep sea of the Bay. of Tokyo was used.

In recording the experimental results, the weighted means were generally taken for their final means of mean values. The density and viscosity of fresh water and sea-water were all measured by using a pyknometer and a viscometer (capillary tubes when necessary).

\section{Temperature Effect on the Resistance of Planks and Ship-models of a Rough Surface.}

§5. Recognizing the importance of testing planks and ship-models of a rough surface before entering into the investigation of smooth-surface resistance, rough-surface experiments were made.

Some 5- and 8-foot plates coated with fine iron powders were tested at a constant draught of 6 inches, and at various temperatures between $39^{\circ}$ and $120^{\circ} \mathrm{F}$., and it was found that the whole resistance, i.e., practically the frictional resistance at any constant draught was simply proportional to the density of the water, that is to say $R_{f} / \rho$ was constant, independent of the kinematic viscosity of the water, and $R_{f} / \rho$ to base $V$ curves at several constant temperatures assumed one curve as shown in Figs. 2 and 3, Plate II, and as $R_{f} / \rho \infty V^{2}$,

$$
\text { therefore, } \quad R_{f} / \rho \infty V^{2} \nu^{0} \text {. }
$$

With three ship-models having the same rough surface above referred to, the total resistance of each model at any constant speed and at the temperatures ranging between $41^{\circ}$ and $119^{\circ} \mathrm{F}$. was also simply proportional to the density of the water, and (total resistance) $/ \rho$ to base $V$ curves at various temperatures assumed one curve as shown in Figs. 4, 5 and 6, Plate II. With planks it was already ascertained, that $R_{f} / \rho$ is independent of $\nu$, and as anticipated with ship-models it was found that $R_{f} / \rho$ and (Residuary resistance) $/ \rho$ were also independent of $\nu$. In Figs. 2 to 6 , (Resistance) $\times \rho_{55^{\circ} \mathrm{F} .} / \rho_{t^{\circ} \mathrm{F} \text {. Was }}$ used instead of (Resistance)/ $\rho$.

\section{Temperature Effect on the Frictional Resistance of Planks of a Smooth Surface.}

$\S 6$. For the investigation of the temperature effect on the resistance of smooth surface planks, finding the necessity of looking into the question of an existence of 
"edge effect" pointed out by Gebers ${ }^{(5)}$ and Perring, ${ }^{(6)}$ and the temperature effect on the edge effect, 4-, 5-, 6- and 8-foot lacquered plates were tested at a certain fixed temperature at various draughts, and for each draught $d, R_{f}$ to base $V$ curve was plotted and next, $R_{f}$ to base $d$ curves corresponding to several constant speeds were prepared, and a similar process was repeated for other temperatures.

Take for example, the 5-foot plate: when it was towed at 2-, 3-, 3.98- and 6-inch draughts at a constant temperature of $102^{\circ} \mathrm{F}$., $\log R_{f}$ to base $\log V$ curves at various draughts assumed straight lines almost parallel to one another as shown in Fig. $12_{\mathrm{c}}$, Plate III, and confirmed $R_{f} \infty V^{n}$; and $n$ being $1.908,1.900,1.890$ and 1.902 respectively, it could be taken as independent of the draught as shown in $n$ to base $d$ curve (Fig. 12, Plate III) with a mean value 1.900. $R_{f}$ to base $d$ curves at several constant speeds (Fig. 12a, Plate III) formed a group of straight lines, and when extended met at a point where the negative draught is $x$ ( $x=0.66$ inch) on the base line, that is to say, the resistance at all speeds becomes zero when $d+x=0$, proportional to $d+x$, and at the zero draught will have a certain value corresponding to the speed, showing an existence of a similar nature as the edge effect pointed out by Gebers on his 5-metre plank. And the fact that $R_{f}$ to base $d$ curves form of straight lines meeting at a point on the base line means that if $R_{f}=K V^{n}$ at a certain draught, it will hold good at any other draught. This will be commented on in $\S 25$, Part II, but the above peculiarity will appear only with very thin planks. With thicker planks, $n$ will be increased with an increase of draught, and $R_{f}$ to base $d$ curves will not be straight lines, therefore the edge effect will require a further investigation.

Again the same plate was tested at various draughts at temperatures of $40.4^{\circ}$, $50.5^{\circ}$ and $80.9^{\circ} \mathrm{F}$., and a similar peculiarity was observed as shown in Figs. $9_{\mathfrak{a}}, 10_{\mathfrak{a}}$ and $11_{\mathrm{a}}$, Plate III. Of course, the values of resistance were changed according to the temperatures, but at any temperature, $n$ was independent of the draught, and the mean values at the above-mentioned temperatures were 1.904, 1.907 and 1.888 (Figs. $9_{\mathrm{b}}, 10_{\mathrm{b}}$ and $11_{\mathrm{b}}$, Plate III), and with 1.900 at $102.0^{\circ} \mathrm{F}$. these could be taken as independent of the temperature, and the mean value for various temperatures was $1.901 . \quad R_{f}$ to base $d$ curves at several constant speeds for each of the above temperatures assumed straight lines and met at a point on the base line, and $x$ was always 0.66 inch, therefore $x$ was independent of the temperature.

(5) Schiffbau, April 20, 1920.

(6) Trans. I.N.A., 1926. 
Also similar tests were made on the 4 -foot plate (Figs. $7_{a}, 7_{b}$ and $8_{\mathfrak{a}}, 8_{b}$, Plate III) and the 8 -foot plate (Figs. $13_{\mathrm{a}}, 13_{\mathrm{b}}$ and $14_{\mathrm{a}}, 14_{\mathrm{b}}$, Plate III) and quite similar results were obtained, i.e., the final means of $n$ were 1.902 and 1.907 respectively, and $x$ were 0.73 and 0.46 inch respectively. Further, the 6 -foot plate (Figs. $15_{\mathrm{a}}, 15_{\mathrm{b}}$, Plate III) was tested for only one temperature, and $n=1.917$ and $x=0.59$ inch were obtained.

Therefore, for a certain plate at any draught and temperature,

$$
R_{f} \infty V^{n} \text {, }
$$

and at any speed and temperature,

$$
R_{f} \infty(d+x) \quad \text { or } \quad R_{f} \infty 2 L(d+x) .
$$

The relation of $x$ and $2 L x$ with the length is as shown in Fig. 16, Plate III. Although $x$ for a certain plate is independent of the draught, speed and temperature, it decreases as the length of the plate increases, i.e., a great effect of the length on the edge effect should not be overlooked.

$2 L x$ or the augmentation of surface has an almost maximum value between 7 -feet and 8-feet. The thicknesses of the plates used in these tests were proportional to their respective lengths and were $0.16,0.20,0.24$ and 0.32 inch. 6 - and 8-foot plates with 0.20 -inch thickness were also tested, but no difference was observed.

With the 4-foot plate, as shown in Figs. $7_{\mathrm{b}}$ and $8_{\mathrm{b}}$, at $38.6^{\circ}$ and $76.1^{\circ} \mathrm{F}$., the second or higher critical speed of about 440 and $390 \mathrm{ft}$. per min. respectively was observed, i.e., with that speed as a limit, the value of $n$ suddenly changes, and in the case of this plate, at the respective temperature, its value below that speed becomes 2.094 and 2.109 respectively, and above that speed 1.900 and 1.904 respectively. From other experiments this may be taken as the second or higher critical speed, and with the planks not exceeding 2 feet in length, there is an existence of another critical speed at a lower point which may be taken as the first or lower critical speed. With the 4-foot plate, the first critical speed did not appear. The range between these two critical speeds is a range of unstable flow. Having the knowledge of the existence of so-called second critical speed with a 4 -foot plate, and its entire absence with 5 -foot and longer planks, also of the fact that above the second critical speed, even with short planks such as 4 -foot, the value of $n$ becomes 1.900 as in the case of longer planks, any plank even less than 4 feet in length may be used for investigations on the frictional resistance if the resistance above that speed only is taken. The critical speed will be further discussed in Appendix I.

$\S 7$. The edge effect being independent of the temperature, its virtual surface area is constant if a plate is tested at a constant draught in spite of any change in temperature. Therefore; for observing the temperature effect, 4- and 5-foot lacquered 
plates, and an 8-foot varnished plate were tested, each at 6-inch draught with the greatest possible range of temperature.

The 5-foot lacquered plate was tested at eight different temperatures of $39.9^{\circ}, 42.9^{\circ}$, $50.9^{\circ}, 71.9^{\circ}, 78.9^{\circ}, 99.7^{\circ}, 103.5^{\circ}$ and $120.2^{\circ} \mathrm{F}$., and $R_{f}$ to base $V$ curves (five of them are shown in Fig. $18_{\mathrm{a}}$, Plate IV) were prepared. And from these curves $\log \left(R_{f} / \rho\right)$ to base $\log \nu$ curves for fourteen different speeds (Fig. $18_{\mathrm{b}}$, Plate IV) were plotted. But as all of these curves were observed to be straight lines and parallel to one another, therefore, $R_{f} \infty \rho \nu^{m}$,

where $m$ at any speed was almost 0.165 , and when $m$ to base $V$ curve (Fig. 18, Plate IV) was plotted, it was found to be independent of $V$ with its mean value of 0.165 . Further, from the results of the tests at 3 -inch draught, and at $39.4^{\circ}, 50.4^{\circ}, 81.4^{\circ}, 100.6^{\circ}$ and $120.0^{\circ} \mathrm{F}$., it was also found to be, as shown in $m$ to base $V$ curve (Fig. $18_{\mathrm{c}^{\prime}}$, Plate IV) independent of $V$ with its mean value of 0.165 .

With the 4-foot lacquered plate (Figs.17a $17_{\mathrm{b}}, 17_{\mathrm{c}}$, Plate IV) and the 8-foot varnished plate (Figs. 19 a 19 , 19 , Plate IV), similar results were also obtained, and in each case, the mean value of $m$ was found to be 0.165 , assuring that in all $m$ to base $V$ curves $m$ is independent of $V$.

Exactly the same results were obtained from the experiments made on 5-foot (at 3- and 6-inch draughts) and 8-foot (at 6-inch draught) plates coated with anti-fouling composition at $40^{\circ}$ and $80^{\circ} \mathrm{F}$., and on 6- and 8-foot (each with 6-inch draught) lacquered plates at $39^{\circ}$ to $82^{\circ} \mathrm{F}$, therefore, at any draught and speed, the following relation is established for various smooth surfaces:

$$
R_{f} \infty \rho \nu^{0.165},
$$

and as explained in the foregoing paragraph and as may be seen from $\log R_{f}$ to base $\log V$ curves (Figs. 17e and $19_{\mathrm{e}}$, Plate IV) obtained from the test results of the 4- and 8-foot plates, the relation of $R_{f}$ and $\nabla$ may be represented by $R_{f} \infty V^{n}$. Further, as shown in $n$ to base temperature curves (Figs. $17_{\mathrm{d}}, 18_{\mathrm{d}}, 18_{\mathrm{d}^{\prime}}$ and $19_{\mathrm{d}}$, Plate IV), $n$ may be taken as independent of the temperature, and its mean values for the 4- and 5-foot lacquered plates, and the 8-foot varnished plate become 1.900, 1.906 (1.912 at 3-inch draught) and 1.904 respectively.

Again considering all $n$-values, regardless of the temperature, the values of $n$ for all plates mentioned in the foregoing and present paragraphs are clearly found to be independent of the draught, and its mean values for the 4-, 5-, 6- and 8-foot lacquered plates become 1.902, 1.900, 1.900 and 1.900 respectively, and in plotting these values on the length-base, Fig. 22, Plate $\mathrm{V}$ was prepared, and from which $n$ may be found to be 
also independent of the length with its final mean value 1.900. The tests for the 8-foot varnished plate were made only for 6 -inch draught, but its mean value being observed to be 1.904 or practically 1.90 , the latter may be taken as a constant value of $n$ for all such smooth plates.

Therefore, apart from plates of different lengths, the following relations may hold good for one plate:

At any speed and temperature, $\quad R_{f} \infty 2 L(d+x)$;

At any draught and speed, $\quad R_{f} \infty \rho \nu^{0.165} \quad$;

At any draught and temperature, $\quad R_{f} \infty V^{1.90} \quad$;

and at any draught, speed and temperature,

$$
\begin{aligned}
& R_{f}=K\left\{2 L(d+x) V^{1.90} \rho \nu^{0.165}\right\} \ldots \ldots \ldots \ldots \ldots \ldots \ldots \text { (1) } \\
& =K S(1+2 L x / S) V^{1.90} \rho \nu^{0.165} \\
& =K S(1+x / d) V^{1.90} \rho \nu^{0.165}
\end{aligned}
$$

$K$ being a constant depending on the nature of surface.

$\S 8$. The equation $\left(1^{\prime}\right)$ and $\left(1^{\prime \prime}\right)$ may be written for temperatures $t^{\circ} \mathrm{F}$. and $55^{\circ} \mathrm{F}$.,

$$
\begin{aligned}
& \left(R_{f}\right)_{t^{\circ} \mathrm{F} .}=K_{1} S\{1+(L x) /(6 S)\} V_{K}^{1.90}\left({ }_{\rho} \nu^{0.165}\right)_{t^{\circ} \mathrm{F} .} \\
& =K_{1} S(1+x / d) V_{K}^{1.90}\left(\rho \nu^{0.165}\right) t^{\circ} \\
& \left(R_{f}\right)_{55^{\circ} \mathrm{F} .}=K_{1} S\{1+(L x) /(6 S)\} V_{K^{1.90}}\left(\rho \nu^{0.165}\right)_{55^{\circ} \mathrm{F} .} \\
& =K_{2} S\{1+(L x) /(6 S)\} V_{K}^{1.90} \\
& =K_{2} S(1+x / d) V_{K}^{1.90} \\
& =\left(R_{f}\right)_{t^{\circ} \mathrm{F} .} \times\left(\rho \nu^{0.165}\right)_{55^{\circ} \mathrm{F} .} /\left(\rho \nu^{0.165}\right)_{t^{\circ} \mathrm{F} .},
\end{aligned}
$$

where $K_{2}=K_{1}\left(\rho \nu^{0.165}\right)_{55^{\circ} \mathrm{F} .}=0.303 K_{1}$;

and

$$
\begin{aligned}
& R_{f} \ldots \ldots \ldots \ldots \ldots \ldots \ldots \text { Frictional resistance in } \mathrm{lb} \text {., } \\
& S \ldots \ldots \ldots \ldots \ldots \ldots \ldots \text { Actual skin area in } \mathrm{ft.}^{2} \text {, } \\
& L \ldots \ldots \ldots \ldots \ldots \ldots \ldots \text { Length in ft., } \\
& \text { d............... Draught in inches, } \\
& x \ldots \ldots \ldots \ldots \ldots \ldots \ldots \text { Edge effect in inch, } \\
& V_{K} \ldots \ldots \ldots \ldots \ldots \ldots \text { speed in knots, } \\
& \text { ค } \ldots \ldots \ldots \ldots \ldots \ldots \ldots \text { Density in } 1 b . \mathrm{ft}^{-4} \times \text { sec. }^{2} \text {, } \\
& \boldsymbol{\nu} \ldots \ldots \ldots \ldots \ldots \ldots \ldots \ldots \text { Kinematic viscosity in } \mathrm{ft}^{2} \times \mathrm{sec}^{-1} \text {, } \\
& K_{1} \text { and } K_{2} \ldots \ldots \ldots \ldots \ldots \ldots \text { Resistance coefficients depending on the } \\
& \text { nature of surface. }
\end{aligned}
$$

Now, if for each of the 4-, 5-, 6- and 8-foot lacquered plates, $K_{2}$ is calculated from all the measured resistance, whatever be the draught, speed and temperature, and plotted on the speed-base, it will be clearly seen, as shown in Figs. $23_{\mathfrak{a}}, 24_{\mathfrak{a}}, 25_{\mathfrak{a}}$ and $26_{\mathfrak{a}}$, Plate 
$\mathrm{V}$, that for all of the plates is independent of the speed and is a constant, proving the truth of $R_{f} \infty V^{1.90}$. Its mean values for each length of the plates are 0.00963, 0.00981, 0.00965 and 0.00980 , and the values of $K_{1}$ become $0.0318,0.0324,0.0318$ and 0.0323 respectively.

Further, in plotting $K_{2}$ on the $V d$-base for the 5- and 8-foot plates as shown in Figs. $24_{b}$ and $26_{b}$, Plate $V, K_{2}$ will be seen to be also a constant, independent of $V d$ with its mean values as stated above assuring the truth of $R_{f} \infty(d+x)$. Also for the 8-foot varnished plate (Fig. $26_{\mathfrak{a}}{ }^{\prime}$, Plate V), if $x$ for the lacquered plate of the same length is assumed, the mean value of $K_{2}$ will be 0.00988 , and that of $K_{1}$ be 0.0326 . Therefore, the equation (2) and (3) have been proved to be a satisfactory representation of the experimental values for each plate.

$\S 9$. The observation of the variation of $R_{f}$ for the change of $V, v$, or both $V$ and $\boldsymbol{\nu}$ on one plate at a constant immersion may cancel several doubts accompanying the change of dimensions. In this case, $S, L$ and $x$ being constants, the equation (1) may be written as

$$
R_{f}=\text { constant } \times \rho V^{2}\left(V^{-0.10} / \nu^{-0.165}\right)
$$

different from one of the modern accepted forms

$$
R_{f}=C \rho S V^{2}(V L / \nu)^{N}=\text { constant } \times \rho V^{2}(V / \nu)^{N} .
$$

During the experiments, when $n$ in $V^{n}=1.90$ was obtained, $m$ in $\nu^{m}=0.10$ was anticipated, and when $m=0.165$ was obtained, $n=1.835$ was anticipated, but as the final result the above form was obtained and is different from the original expectation.

Again the results (as shown in Fig. 18, Plate IV and from a few other experiments) of the temperature effect on the 5 -foot lacquered plate at 6 -inch draught were examined by applying them to another modern form

$$
R_{f}=\rho S V^{2}\left\{a+b(V L / \nu)^{M}\right\} \text { or } \frac{R_{f}}{\rho S V^{2+M}}=a V^{-M}+b(L / \nu)^{M} .
$$

If the experiments conform with this equation, then $R_{f} /\left(\rho S V^{2+M}\right)$ to base $V^{-M}$ curves at several constant temperatures, become parallel straight lines making an angle $\tan ^{-1} a$ with the base line, and the quotients obtained by dividing the intercept on the $y$-axis by $L^{\boldsymbol{M}} \boldsymbol{\nu}^{-\boldsymbol{M}}$ become $b$, i.e., a constant. Now if, for the values of $M$, the familiar values $-1 / 2$ and $-1 / 3$, and a conventional value -0.10 were assumed, then in $\mathrm{ft}$. lb. sec. unit,

Case (1) $\quad M=-1 / 2 \ldots R_{f}=\rho S V^{2}\left\{a+b(V L / \nu)^{-1 / 2}\right\} \ldots$ (Fig. 28, Plate V).

For low temperatures of the water, curves obtained may be practically straight lines, but for higher temperatures, curves will tend to become concave towards the base line at 
high speeds. Therefore, as shown in Fig. $28_{\mathfrak{a}}$, if these curves were provisionally drawn as parallel straight lines following those of low temperatures, then $a=0.00161$ will be obtained, and it will be observed that at higher temperatures and speeds, the actuai spots appear further out below the straight lines. It is noteworthy that exactly the same tendency could be clearly detected in Shigemitsu's clean brass-plate cylinder rotating in water. ${ }^{(7)}$ Also $b$ is not a constant, and diminishes as the temperature increases.

The values of $a$ and $b$, together with their values for other conditions are shown in Table I.

Case (2)

$$
M=-1 / 3 \ldots \ldots R_{f}=\rho S V^{2}\left\{a+b\left(\frac{V L}{\nu}\right)^{-1 / 3}\right\} .
$$

There is an exactly the same tendency as (1), and if provisional straight lines are drawn, then $a=0.00137$ will be obtained. But in this case, curves are approaching to be more parallel straight lines than those for (1), and also $b$ tends to approach a constant.

Case (3) $\quad M=-0.10 \ldots R_{f}=\rho S V^{2}\left\{a+b\left(\frac{V L}{\nu}\right)^{-0.10}\right\} \ldots$ (Fig. 28, Plate V). All curves become straight lines parallel to the base line, and $a=0$ and $b$ is almost constarit, still having a tendency of diminishing as the temperature increases as in (1) and (2), and the equation will take the following form:

$$
\frac{R_{f}}{\rho S V^{1.90}}=b\left(\frac{L}{\nu}\right)^{-0.10}
$$

Case ( $\left.3^{\prime}\right)$ If in the foregoing case the intercept on the $y$-axis is divided by $L^{-0.165} \nu^{0.165}$ and the quotient obtained is called $b_{1}$, then $b_{1}$ is a constant, perfectly independent of the temperature. Therefore, the equation conforming with the experi+ mental results will naturally be

$$
\frac{R_{f}}{\rho S V^{1.90}}=b_{1}\left(\frac{L}{\nu}\right)^{-0.165}
$$

where $b_{1}$ and $L$ are constants.

$b_{1}$ being a constant independent of the temperature, and its mean value being 0.0172 ,

or

$$
\begin{aligned}
& R_{f}=0.0172 \rho S V^{1.90} L^{-0.165} \nu^{0.165}, \\
& R_{f}=0.0467 \rho S V_{K}^{1.90} L^{-0.165} \nu^{0.165} \\
& \text { in ft. lb. sec. unit and } V_{K} \text { only in knots, } \\
& \quad=0.0358 S V_{K}^{1.90} \nu^{0.165} \text { for } L=5 \text { feet .... }
\end{aligned}
$$

But, inserting $K_{1}=0.0324$ in $\S 8$ to the equation $\left(2^{\prime}\right)$, it gives

(7) See Fig. 10, Jour. Soc. N.A., Japan, Vol. 41, 1928, p. 78. 


$$
\begin{aligned}
R_{f} & =0.0324 S(1+x / d) V_{K}^{1.90} \nu^{0.165} \\
& =0.0360 S V_{K^{1.90}} \nu^{0.165} \text { for } d=6 \text { inches and } x=0.66 \text { inch........ (4'). }
\end{aligned}
$$

The coincidence of the numerical coefficients in (4) and $\left(4^{\prime}\right)$ is a proper result.

If the experimental results of the 8-foot lacquered plate at 6 -inch draught mentioned in $\S 7$ were represented by $\frac{R_{f}}{\rho S V^{2}}$ to base $\frac{V L}{\nu}$ curve (Fig. $28_{c}$, Plate V), at higher values of $\frac{V L}{\nu}$, the curves for all temperatures almost coincide with one another and at a glance $\frac{R_{f}}{\rho S V^{2}}$ might be recognized as $f\left(\frac{V L}{\nu}\right)$. In short, it is difficult to extract a small difference by this method of presentation.

\section{Frictional Resistance of Short Planks.}

$\S 10$. By plotting the mean $K_{2}$ on the length-base for each of four planks of different lengths described in $\S 8$, Fig. 27, Plate $V$ was obtained, and in which no effect whatever of the length would be observed, i.e., $K_{2}$ in equation (3) and also $K_{1}$ in equation (2) may be regarded as constants, independent of the length, and as the final value of 938 experiments, $K_{2}=0.00974\left(K_{1}=0.0321\right)$ was obtained. Therefore, for 4 - to 8 foot lacquered plates equations (1), (2) and (3) become applicable to all lengths, and

$$
\begin{aligned}
\left(R_{f}\right)_{55^{\circ} \mathrm{F} .} & =0.00974 S\{1+(L x) /(6 S)\} V_{K}^{1.90} \ldots \ldots \ldots \ldots \ldots(5) \\
& =0.00974 S(1+x / d) V_{K^{1.90}} \ldots \ldots \ldots \ldots \ldots \ldots \ldots\left(5^{\prime}\right) \\
R_{f} & =0.0321 S\{1+(L x) /(6 S)\} V_{K}^{1.90} \rho \nu^{0.165} \ldots \ldots \ldots \ldots(6) \\
& =0.0321 S(1+x / d) V_{K}^{1.90} \rho \nu^{0.165} \ldots \ldots \ldots \ldots \ldots\left(6^{\prime}\right)
\end{aligned}
$$

Therefore, the frictional resistance per unit area of smooth thin planks may be taken to consist of two parts; one being the net skin resistance, is a constant part, entirely independent of the length and other dimensions, and the other being the resistance augmented by the edge effect, diminishing with the increase of the length. And the sum of these two parts, i.e. the total frictional resistance per unit area, is a constant, only at the draught having $x / d=$ constant, and diminishes with the increase of the length at a constant draught or at a similar draught, and tends to approach to a constant with a large draught.

In the foregoing paragraph, it was stated that even if one plate was kept at a constant draught, $R_{f}$ is not the function of $V L / \nu$, it was also found as stated above, that the net resistance for plates of different lengths is independent of the length.

Considered from the principle of dimensional homogeneity, $K, K_{1}$, or $K_{2}$, etc. should have dimensions such as $V^{-0.065} L^{-0.165}$ or $L^{-0.10} \nu^{-0.065}$, i.e., $[L]^{-0.230}[\mathrm{~T}]^{0.065}$, but as the experimental results, they actually come out to be a constant. Truly the author is at 
a loss for an explanation of this inconsistency, but such was the actual experimental results, calling forth an immediate necessity of long-plank experiments.

\section{Temperature Effect on the Resistance of Smooth Ship-models.}

$\S 11$. In order to observe the temperature effect on the total resistance of shipmodels having a smooth surface, two standard models of 4 feet and 5 feet, a 4 -foot cruiser-model and a 5-foot battleship-model were tested at the water temperature ranging from $40^{\circ} \mathrm{F}$. to $138^{\circ} \mathrm{F}$., and the total resistance to base speed curves as shown in Figs. $29_{\mathrm{a}}, 30_{\mathrm{a}}, 31_{\mathrm{a}}$ and $32_{\mathrm{a}}$, Plate VI were obtained. To find the frictional resistance $\left(R_{f}\right)_{t}$ from the total resistance $(R)_{t}$ at any temperature $(t)$, the temperature $(T)$ having the greatest number of experimental spots was selected for each model, $\left(67.2^{\circ}, 66.6^{\circ}, 59.7^{\circ}\right.$ and $66.9^{\circ} \mathrm{F}$. respectively), and $\left(R_{f}\right)_{T}$ for that temperature was calculated, and the result was reckoned as a basic friction of that model. In calculating $\left(R_{f}\right)_{T}$, it was assumed that a model is equivalent to a smooth-surface plank having the surface of the same nature and the same area, and an edge effect only was modified as a model from the plate of the same length, i.e., the following formula (which will be explained later in $\S 26$ to 29 , Part II) was used:

$$
\left(R_{f}\right)_{T}=K_{1} S\left\{1+\frac{\left(L^{\prime}+C L\right) x}{6 S}\right\} V_{K^{1.90}}\left(\rho \nu^{0.165}\right)
$$

where $K_{1} \ldots \ldots$ Resistance coefficient obtained by the plank experiment,

$x$......Edge effect obtained by the plank experiment for 5 -foot models, and 0.56 inch for 4 -foot models,

$L^{\prime} \ldots \ldots$. The length of keel excluding the length of cut-up portion of the keel at the after part of the ship,

$C$....... Coefficient of scale effect of models which is a constant for similar models at a similar draught and varies with the form of the model, and is equal to 0.65 for the standard models, 0.75 for the cruiser and 1.23 for the battleship-model.

$\left(R_{f}\right)_{T}$ so calculated, was deducted from the total resistance $(R)_{T}$ at that temperature $(T)$, and the residuary resistance $\left(R_{r}\right)_{T}$ was obtained. $R_{r} / \rho$ being constant at any temperature by $\S 5$, at other temperature $t, R_{r} / \rho$ was deduced from $(R / \rho)_{t}$ and $\left(R_{f} / \rho\right)_{t}$ was obtained.

Now, in plotting out $\log \left(R_{f} / \rho\right)$ to base $\log \nu$ curves at several constant speeds (Figs. $29_{\mathrm{b}}, 29_{\mathrm{c}}, 30_{\mathrm{b}}, 30_{\mathrm{c}}, 31_{\mathrm{b}}, 31_{\mathrm{c}}, 32_{\mathrm{b}}, 32_{\mathrm{c}}$, Plate VI), ( $\left.R_{f} / \hat{\rho}\right) \infty \boldsymbol{\nu}^{m}$ form was obtained the same as with planks, and $m$ being independent of the speed, its mean value was 0.163 for the 
4-foot cruiser-model, and 0.165 for each of other three models, and the mean of four models was 0.165 . Therefore, as with planks, the frictional resistance of a model at any given speed, may be expressed by

$$
R_{f} \infty \rho \nu^{0.165} \text {. }
$$

In arriving at this result, there is a weak point in assuming the basic frictional resistance at the start. If the above result were not obtained as a final solution, there would be the necessity of introducing another assumption, but as it is, i.e., since the assumption agrees with the result, there will be no objection.

However, for a trial, if 10 per cent. difference was assumed for the basic friction for the 5-foot standard model, and finding $m$ by the similar method, with 110 per cent. and 90 per cent. as basic friction, it was found that, though in the latter case $m$ has a tendency to diminish with the increase of speed, generally speaking $m$ is constant, with its mean values of 0.151 and 0.185 respectively. Therefore, if 1 per cent. difference was given to the basic friction, then $m$ will be 0.164 and 0.167 respectively, but the fact that $m=0.165$ was actually obtained seems to manifest a suitability of the estimate for frictional resistance. Further, the residuary resistance curve at $66.6^{\circ} \mathrm{F}$. for the 5 -foot standard model obtained by an assumption of $R_{f}$ at the same temperature, and also that deduced from the residuary resistance at $67.2^{\circ} \mathrm{F}$. obtained by the similar assumption for the 4-foot standard model are shown in Fig. $30_{\mathbf{a}}$ and it will be seen that they conform perfectly with each other.

\section{Percentage Variation of the Frictional Resistance of Smooth Planks and Models with the Change of Temperature.}

$\S 12$. It would be convenient for finding $\left(R_{f}\right)_{t}$ at any temperature $t^{\circ} \mathrm{F}$. from

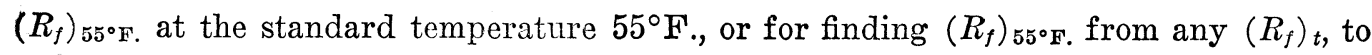
use the following " $a$ " coefficient:

$$
a\left(R_{f}\right)_{55 \cdot \mathrm{F} .}=\left(R_{f}\right)_{t},
$$

where $a=\left(\rho \nu^{0.165}\right)_{t^{\bullet}} /\left(\rho \nu^{0.165}\right)_{55^{\circ} \mathrm{F} .}=\frac{1}{0.3033}\left(\rho \nu^{0.165}\right)_{t^{\bullet}}$;

and, to use the following " $b$ " coefficient to find the rate of variation for $10^{\circ} \mathrm{F}$. change at $t^{\circ} \mathrm{F}$.:

$$
b=\frac{\left(R_{f}\right)_{t^{\bullet}-5^{\circ} \mathrm{F} .}-\left(R_{f}\right)_{t^{\circ}+5^{\bullet} \mathrm{F}}}{\left(R_{f}\right)_{t^{\bullet}}}=\frac{\left(\rho \nu^{0.165}\right)_{t^{\bullet}-5^{\circ} \mathrm{F} .}-\left(\rho \nu^{0.165}\right)_{t^{\circ}+5^{\circ} \mathrm{F} .}}{\left(\rho \nu^{0.165}\right)_{t^{\bullet}}}
$$

The $a-$ and $b$-values are as shown in $a$ to base $t^{\circ} \mathrm{F}$. curve and $b$ to base $t^{\circ} \mathrm{F}$. curve (Figs. 20 and 21, Plate IV) and also as follows: 


$\begin{array}{ccccccccc}t^{\circ} \mathrm{F} . \ldots \ldots \ldots \ldots & 40 & 50 & 55 & 60 & 70 & 80 & 90 \\ a & \ldots \ldots \ldots & 1.039 & 1.012 & 1.000 & 0.988 & 0.966 & 0.944 & 0.924 \\ b & \% \ldots \ldots \ldots & 2.63 & 2.50 & 2.45 & 2.39 & 2.27 & 2.17 & 2.07\end{array}$

It will be seen that at $55^{\circ} \mathrm{F}$. the variation per $10^{\circ} \mathrm{F}$. is $2.45 \%$, and at $80^{\circ} \mathrm{F}$. is $2.17 \%$. In places, such as one finds in certain parts of Japan where there is a change of water temperature from $40^{\circ} \mathrm{F}$. in winter to $80^{\circ} \mathrm{F}$. in summer, there is a variation of from 1.039 to 0.944 times $\left(R_{\mathrm{f}}\right)_{55^{\circ} \mathrm{F} \text {, }}$, with as much as $9.5 \%$ difference.

$\S 13$. Temperature-effect experiments for planks were made only for very thin planks having sharp ends and sharp edge. The author regrets not having had experiments carried out for other forms, i.e., round edge or rounded ends, particularly when it is quite clear that the latter contains the form resistance or other kinds of resistance, while even the former may have some effect with short planks. However, at present, the author is satisfied to find a perfect conformity between ship-models and planks having a sharp edge and sharp ends.

Not having any record of systematic experiments on planks and models with an artificial temperature variation given to the tank water, the experiments of the temperature effect made by rotating a dise or cylinder in water, i.e., Unwin's experiment of a clean polished disc, ${ }^{(8)}$ and Shigemitsu's experiment of a clean brass cylinder, ${ }^{(9)}$ were taken. It will be seen that the variation between extreme temperatures is practically the same with our results as shown in Table II. In $1915, R_{f}=K \rho S V^{2}(V L / \nu)^{-0.138}$ was proposed by the Froude Tank, also in 1921, $R_{f}=c \rho S V^{2}(V L / \nu)^{-0.125}$ by Gebers. In either case, it appears that the index of $\nu$ is not obtained from experimental results, but merely derived from the index of $V L$, therefore cannot be used as a comparison. The Hasler practice is said to be $3 \%$ for $10^{\circ} \mathrm{F}$. change, so it is a little greater than that given by $\rho \nu^{0.165}$.

\section{Effect of Sea-Water on the Resistance of Planks and Ship-models.}

$\S 14$. In converting the resistance in fresh water into that in sea-water a usual practice appears to be simply a density correction, and needless to say, this correction forms one of the important parts of deducing the tank experiments into an actual ship. After carrying out temperature-effect experiments from the standpoint of a practical necessity or of studying the nature of the frictional resistance, a natural desirability

(8) Unwin, “A Treaties on Hydraulics," pp. 140-141.

(9) loc. cit. 
is to have experiments in sea-water. In this connection, the author again took advantage of the size of the small Tank and the proximity of the Tank from the sea-shore, and in 1930, taking in clean sea-water into the Tank, carried out the desired experiments.

Planks and models used for experiments were one rough plate, two smooth plates and five ship-models, their dimensions and the results are shown in Table III. For each of them, fresh-water experiments were made just before changing the tank water into sea-water, and the resistance to base speed curves were prepared, and the resistance in sea-water at any speed obtained from the experiments was compared with the resistance in fresh water corrected to the temperature of sea-water at that speed obtained from the above curves, but the temperature difference was found to be no more than $6.2^{\circ} \mathrm{F}$.

$\S 15$. For an 8 -foot plate of a rough surface, after ascertaining the independency of the resistance on $\nu$ in sea-water, varying draught tests were made to observe the existence of the edge effect for a rough surface, and the results obtained are shown in Fig. 33a, Plate VII, and from which the following facts may be observed: (a) With a rough surface in either fresh water or sea-water, $n$ in $V^{n}$ for a draught variation is constant as shown in Fig. 33 , Plate VII, and its mean value is 2.020 in either case, there being no difference between these two fluids, (b) with a rough surface in either fresh water or sea-water, the edge effect of the same nature exists with $x=0.46$ inch, therefore at the same draught, the augmentation of surface area is the same, and its value is equivalent to the case of the 8 -foot lacquered plate. However, this was found later to be limited only to the case of the 8-foot plate. With other Iengths, a rough surface exhibits a different nature from a smooth surface, having the edge effect $x$ not so much affected by the length as the latter.

Thus at a constant draught, having obtained the resistance ratio $\left(R_{f}\right)_{S W} /\left(R_{f}\right)_{F W}$ of two fluids at the same temperature for several constant speeds, and ascertaining that the ratio is independent of the speed, and obtaining its mean values, the final mean value for three draughts was arrived at (Fig. $33_{\mathrm{c}}$, Plate VII). In short, at $77.9^{\circ} \mathrm{F}$. the resistance' ratio is always almost equal to the density ratio 1.0228 , and is independent of $\nu$, and the final mean value 1.0230 is obtained. Therefore, the resistance of a rough suriace in two kinds of fluid may be taken to be simply proportional to the density.

$\S 16$. In the experiments made on 6- and 8-foot lacquered plates, each at three draughts (Figs. 35, and $34_{\mathrm{a}}, 34_{\mathrm{b}}, 34_{\mathrm{c}}$, Plate VII), (a) $n$ in $V^{n}$ is common to both fresh water and sea-water, 1.901 for the 6-foot plate, and 1.904 for the 8-foot plate were obtained, and (b) the edge effect is also common to both fresh water and sea-water, with 0.59 inch for the 6 -foot plate and 0.46 inch for the 8-foot plate. 
The values of $\left(R_{f}\right)_{S W} /\left(R_{f}\right)_{F W}$ at the same temperature for a given draught were found to be independent of the speed as shown in Fig. $34_{d}$, Plate VII for 6-inch draught of the 8-foot plate. Their mean values for the 6-foot and 8-foot plates, each at three draughts being 1.0271 and 1.0291 respectively, the final mean value is 1.0281 . This case differs from that of the temperature-effect experiments, i.e., having only two kinds of $\nu$ for fresh water and sea-water, there is no way of finding the function of $\rho$ and $\nu$, but it would be proper to expect the existence of the relation of $\left(R_{f}\right)_{S W} /\left(R_{f}\right)_{\mathrm{FW}}=\left(\rho \nu^{m}\right)_{S W} /$ $\left(\rho \nu^{m}\right)_{F W}$. Therefore, using that assumption, 0.164 was obtained for $m$. In these experiments $(\boldsymbol{\nu})_{\mathrm{SW}} /(\boldsymbol{\nu})_{\mathrm{FW}}$ was 1.032 and the measured resistance variation was only 2.8 per cent., thus in spite of the quite unsatisfactory aspect in the accuracy of experiments, practically the same result as the temperature effect was obtained.

For model experiments, 4- and 5-foot standard models, a 6-foot destroyer-model, and two 5-foot gunboat-models (last three are of wood, with varnished surface) were used. The total resistance to base speed curves for the standard models are shown in Figs. $36_{\mathrm{a}}$ and $37_{\mathrm{a}}$, Plate VII. To find $R_{f}$ of a model in fresh water (temperature $t_{F}$ ) and sea-water (temperature $\left.t_{S}\right),\left(R_{f}\right)_{F W . t}$ calculated by the formula $(7)$ in $\S 11$ ( $c$ being 0.65 , 0.74 and 0.94 respectively), was deducted from the total resistance $(R)_{F W . t F}$ in fresh water, and the residuary resistance $\left(R_{r}\right)_{F W . t_{F}}$ was obtained. On the other hand, it would be correct to consider that $R_{r}$ is simply proportional to $\rho$ when there is a change in fluid, i.e., from fresh water into sea-water as in $\S 5$ when there is a change of tempera ture in the same fluid. Therefore,

and

$$
\left(R_{r}\right)_{S W . t S}=\left(R_{r}\right)_{F W . t S} \times \frac{(\rho)_{S W . t .}}{(\rho)_{F W . t . F}}
$$

Assuming $\left(R_{f}\right)_{S W . t s} /\left(R_{f}\right)_{F W . t s}=\left(\rho \nu^{m}\right)_{S W . t s} /\left(\rho \nu^{m}\right)_{F W . t s}$ as in the case of planks, to find the value of $m$ at several constant speeds, it was found that each of the five models is independent of the speed as shown in Figs. $36_{\mathrm{b}}$ and $37_{\mathrm{b}}$, Plate VII for the standard models, and very uniform results of 1.0285, 1.0278, 1.0277, 1.0281 and 1.0284 respectively were obtained. Its mean value being 1.0281, exactly the same value as in the case of planks $m=0.164$ was secured.

$\S 17$. Hence, the effect of sea-water at the same temperature comes to be proportional to $\rho \nu^{0.164}$ for both planks and models, and having $m=0.165$ already obtained from much more accurate temperature-effect experiments, it may be seen that both the temperature effect in fresh water and the effect of sea-water are governed by $\rho \nu^{\mathbf{0 . 1 6 5}}$. Further, from the above result, the temperature effect in sea-water will be, at once, 


$$
\frac{\left(R_{f}\right)_{S W . t_{2}}}{\left(R_{f}\right)_{S W . t_{1}}}=\frac{\left(R_{f}\right)_{S W . t_{2}}}{\left(R_{f}\right)_{F W . t_{2}}} \times \frac{\left(R_{f}\right)_{F W . t_{2}}}{\left(R_{f}\right)_{F W . t_{1}}} \times \frac{\left(R_{f}\right)_{F W . t_{1}}}{\left(R_{f}\right)_{S W . t_{1}}}=\frac{\left(\rho \nu^{0.165}\right)_{S W . t_{2}}}{\left(\rho \nu^{0.165}\right)_{S W . t_{1}}}
$$

Curves on the temperature-base for $(\rho)_{S W},(\rho)_{F W}$ and $(\rho)_{S W} /(\rho)_{F W}\left(\right.$ Fig. 38); $(\nu)_{s W}$, $(\nu)_{F W}$ and $(\nu)_{S W} /(\nu)_{F W}$ (Fig. 39); and $\left(\rho \nu^{0.165}\right)_{S W},\left(\rho \nu^{0.165}\right)_{F W}$ and $\left(\rho \nu^{0.165}\right)_{S W} /\left(\rho \nu^{0.165}\right)_{F W}$ (Fig. 40, Plate VII); are shown and the temperature correction, also the correction for sea-water from the fresh-water result may be directly obtained from these curves.

In short, at $55^{\circ} \mathrm{F}$. or approximately within a scope of prevailing temperatures,

$$
\begin{aligned}
& (\rho)_{S W} /(\rho)_{F W}=1.023, \\
& \left(\rho \nu^{0.165}\right)_{S W} /\left(\rho \nu^{0.165}\right)_{F W}=1.029,
\end{aligned}
$$

and in the frictional resistance, for the usual 1.023-time correction for density, 0.6 per cent. more, i.e., 1.029-time correction should be used.

§18. Therefore, in both fresh water and sea-water, for the temperature change and the change of fluid,

$$
\begin{aligned}
& R_{f}=K_{1} S\{1+(L x) /(6 S)\} V_{K}^{1.90} \rho \nu^{0.165} \\
& \left(R_{f}\right)_{55^{\circ} \mathrm{F} .}=K_{2} S\{1+(L x) /(6 S)\} V_{K^{1.90}}
\end{aligned}
$$

where $K_{1}=0.0321$ for lacquered plates in fresh water and sea-water,

$$
\begin{aligned}
K_{2} & =0.00974, & & & & \text { " fresh water, } \\
& =0.01002, & & & & \text { " }
\end{aligned}
$$

\begin{tabular}{|c|c|c|c|}
\hline & & Zahm's experiment ${ }^{(11)}$ & Resistance per sq. ft. ${ }^{(1)}$ \\
\hline Length & Breadth & $\begin{array}{l}\text { Resistance } \\
\text { per sq. ft., A }\end{array}$ & $\begin{array}{l}\text { calculated from the } \\
\text { new formula }\end{array}$ \\
\hline feet & inches & lb. & lb. \\
\hline 2 & 25.5 & 0.000524 & $0.000561=1.07 \mathrm{~A}$ \\
\hline 8 & 25.5 & 0.000475 & $0.000544=1.15 \mathrm{~A}$ \\
\hline 16 & 25.5 & 0.000457 & $0.000530=1.16 \mathrm{~A}$ \\
\hline
\end{tabular}

The temperature correction for fresh water shown in $\S 12$ and Figs. 20 and 21, Plate IV is applicable to sea-water, so far as $\left(\rho \nu^{0.165}\right)_{S W} /\left(\rho \nu^{0.165}\right)_{F W}$ remains constant.

Taking a further step to see how this formula applies to the friction of thin smooth plates in air, the following references are made:

(a) Zahm's(10) varnished planks of 1-inch thickness at a wind speed of $10 \mathrm{ft}$. per sec. and temperature $24.2^{\circ} \mathrm{C}$.

(b) Stanton's(13) $16 \mathrm{ft} . \times 0.5 \mathrm{ft}$. smooth plate at a wind speed of $30 \mathrm{ft}$. per sec..

(10) Phil. Mag., 1904.

(11) Zahm's resistance per sq. ft. will be increased when 7-inch end pieces are added to.

(12) taking $K_{1}=0.0326$ and $x$ for 2-, 8- and 16-ft. plates with 7-inch end pieces, twice $0.80,0.39$ and 0.095 inch respectively and $\left(\rho_{\nu} 0.165\right)$ air $/\left(\rho_{\nu} 0.165\right)$ water at $24.2^{\circ} \mathrm{C} .=1 / 525$.

(13) Trans. I.N.A., 1925. 
The total resistance of air on one side of the plate in $1 b . \ldots \ldots \ldots \ldots .0317=\mathrm{B}$, Ditto calculated from the new formula at $60^{\circ} \mathrm{F} . \ldots \ldots \ldots \ldots \ldots . . .6347=1.09 \mathrm{~B}$ taking $K_{1}$ for bright brass plate to be $0.0316, x$ twice 0.125 inch and $\left(\rho \nu^{0.165}\right)_{\text {air }} /\left(\rho \nu^{0.165}\right)_{\text {water }}$ at $60^{\circ} \mathrm{F} .=1 / 535$.

\section{Part II. Frictional Resistance of Longer and Shorter Planks and Ship-Models.}

\section{Frictional Resistance of Longer and Shorter Planks of Various Natures of Surface.}

$\S 19$. As the result of the investigations described in Part I, having perceived the necessity of carrying out resistance experiments on longer planks, while continuing the experiments on short planks, the author took up the experiments on longer planks having a possible length of towing in the small Tank and at the same time, in order to check the small-tank results, one of the planks was sent to the Mitsubishi Tank to be tested there.

Planks mentioned in this Part, were 1, 2 and 3 feet in length for short planks, and 14, 20 and 25.774 feet for longer planks, and their surface was mainly of a lacquered nature. Also from the standpoint of practical use and for investigations, painted, paraffin and varnished surfaces, and bright brass plates were used. With a lacquered surface, for those of 14 and 20 feet, wood planks each with a steel heel-strip fitted at the lower edge and covered with a lacquered aluminium plate, were used, and for those of other lengths, brass plates were used. Having ascertained that there was no difference in the frictional resistance between wood and metal, when the surface is of the same nature and finished carefully, wood planks or metal plates were suitably used for those having the surface other than lacquer.

As a general principle, all the planks were tested at various draughts in fresh water. $\rho \nu^{0.165}$ was used for the temperature correction of the frictional resistance.

$\S 20$. With a lacquered surface, in addition to those of 4, 5, 6 and 8 feet, mentioned in Part I, 1-, 2-, 3-, 7-, 14-, 14-(14) and 20-foot planks were tested. It will be observed from these experimental results that:

(a) In all the planks, $R_{f}$ is proportional to $V^{n}$, with the index $n$ independent of the draught (Figs. $41_{\mathrm{b}}$ to $47_{\mathrm{b}}$, Plate VIII), and the mean values of $n$ are shown in the same figures. To these, if the results obtained from other experiments are added, then, 
excepting the 1-foot plank, the mean values become 1.900, 1.903, 1.884, 1.900, $1.919^{(15)}$ and 1.878 respectively in order of the length above mentioned. Further, in referring to the results of four planks mentioned in Part I, it will be seen that the value of $n$ is independent of the length as shown in Fig. 49, Plate VIII, and the final mean value of $n$ from 94 mean values of all the planks having the lengths of 4 feet and above is 1.898. Therefore, the index $n$ was taken to be 1.90 for all lengths, the same as mentioned in Part I. Probably this value of $n$ may appear somewhat low for the 20foot plank, but having $n$-value 1.906 for a 25.774-foot plank with a painted surface (§21), and 1.900 for each of a 20-foot plank with a paraffin surface (§22) and a 20-foot plank with a varnished surface ( $\$ 25$ ), to take $n=1.90$ for a lacquered surface, independent of the length, would not be quite out of place.

(b) With all the planks, there is an existence of the edge effect $x$ (Figs. $41_{\mathrm{a}}$ to $47_{\mathfrak{a}}$, Plate VIII). Its value is independent of the speed and diminishes with the increase of the length of the plank. For instance, it is 0.95 inch with the 1-foot plank, 0.73 inch with the 4 -foot plank, 0.46 inch with the 8 -foot plank, and only 0.05 inch with the 20-foot plank (Fig. 50, Plate VIII). It is nil with the 25.774-foot painted plank, as will be shown in Fig. $53_{\mathrm{a}}$, Plate IX. With a lacquered surface also, probably the edge effect would not exist with a 26 -foot plank. Further, the fact that $2 L x$ is the maximum with the 8-foot plank as expected in Part I should not be overlooked.

(c) Therefore, if $K_{2}$ is calculated from the equation $\left(3^{\prime}\right)$ in $\S 8$, Part $I$, except the 1-foot plank, in order of the lengths, 0.00925, 0.01083, 0.00973 (Fig. 51 ), 0.00974 (Fig. 51 $1_{\mathrm{b}}$ ), 0.00950(16) (Fig. 51 ${ }_{\mathrm{c}}$ ) and 0.00978 (Fig. 51 $1_{\mathrm{d}}$, Plate VIII) respectively will be obtained. And if these values are plotted on the length-base together with the values mentioned in Part I, it will be seen, from Fig. 52, Plate VIII, that they are independent of the length, and the final mean value obtained from 1,307 spots is $0.00974\left(K_{1}=0.321\right)$, and nicely agrees with the result of Part I. Thus the possibility of extending the results of Part $I$ to at least the 20 -foot length was assured.

The comparison of the 14-foot plank tested at the Mitsubishi Tank with the 14-foot plank tested at the small Tank was referred to in $\S 3$, Part I. The values $n=1.919$ and $\boldsymbol{K}_{2}=0.00950$ for the former deviate from those for the latter, i.e., $n$ is greater owing to the less resistance at low speeds and $K_{2}$ is less by about $2 \frac{1}{2}$ per cent. of the latter owing to the less resistance throughout the whole speeds as the result of experiments with three draughts. Although the plate has the greatest thickness of 1.18 inches which exceeds

(15) Tested at the Mitsubishi Tank.

(16) loc. cit. 
$1 / 200$ the length of the plate and it may be considered that the plate has induced a resistance other than friction, as will be shown later on in $\S 25$, yet there was no sign of this, probably due to the triangular section (Fig. 46a ) of the plate which is different in form from the planks in $\S 25$.

(d) The 14-foot plank was specially tested at very small draughts such as 0.56, 0.21 and 0.08 inch and the edge effect similar to that of a deeper draught was observed. Their $R_{f}$ to base $V$ curves are shown in Fig. 45', Plate IX.

(e) In Part I, a question of the second or higher critical speed of the 4-foot lacquered plank was touched. It was also observed with the 3-foot plank. Further, it was observed that with the 2-foot plank, both the first and the second critical speeds begin to appear, and with the 1-foot plank only the first critical speed, these will be described in detail in Appendix I. Therefore, for 2-, 3- and 4-foot planks, both $n$ and $K_{2}$ corresponding to higher speeds than the second critical speeds were taken, and the 1-foot plank was entirely excluded. Also the value of $K_{2}$ for the 2- and 3-foot planks being of a somewhat irregular nature, the values for these planks were excluded, and the final mean values of $n$ and $K_{2}$ were taken from those for 4 feet and above only.

Aspects of $R_{f} \infty V^{n}$ and of an existence of the critical speed for each plank together with those for some lacquered plates in Part I are shown in Fig. 48, Plate VIII.

$\S 21$. For the purpose of applying the experimental results to deduce the resistance coefficient of actual ships and of comparing the nature of the resistance of different surfaces, 2-, 4-, 5-, 6-, 8- and 25.774-foot planks, coated with "Takata" anti-fouling composition were tested at various draughts. From the results it was ascertained that the nature of the resistance of a painted surface is exactly the same as that of a lacquered surface, and the 25.774-foot painted plank being the longest plank used in these experiments, its $R_{f}$ to base $d$ curves and $n$ to base $d$ curves are particularly shown in Figs. $53_{\mathrm{aa}}$ and $53_{\mathrm{ab}}$, Plate IX.

The dimensions of the planks and the results of the experiments are shown in Table IV, together with those for a paraffin surface ( $\$ 22)$ and brass plates $(\$ 23)$.

The experimental results may be summed up as follows:

(a) The value of $n$ was found to be independent of the draught, and as shown in $n$ to base length curve (Fig. $53_{\mathrm{b}}$, Plate IX), it was also found to be independent of the length, and as the mean of 27 values for the planks of 4 feet and above, 1.903 was obtained. Therefore, 1.90 was taken as the final value of $n$.

(b) The edge effect $x$ was found to be independent of the speed, and to diminish gradually with the increase of the length the same as in the case of lacquered planks 
as shown in Fig. 50, Plate VIII. Although its values were smaller in short planks than in lacquered planks of the same length, the difference gradually diminished with the increase of the length, and became practically nil at 14 and 20 feet. At 25.774 feet $x$ entirely disappeared (Fig. $53_{\mathrm{a}}$, Plate IX).

(c) As shown in $K_{2}$ to base length curve (Fig. $53_{\text {c }}$, Plate IX), $K_{2}$ was found to be independent of the length, and as its mean of 629 values 0.01004 was obtained. Therefore, there was only a difference in resistance coefficients between the painted surface and the lacquered surface, with 3.1 per cent. greater resistance in the former than the latter. If $K_{2}$-formula was also applicable to an actual ship, then the resistance coefficient for the actual ship should be 0.01004 in fresh water, or 0.01033 in sea-water.

Further, with planks having a painted surface, no critical speed was observed in the 4-foot plank, and only the second critical speed in the 2-foot plank. This may be taken to be due to a somewhat rougher nature of the painted surface than that of the lacquered surface.

$\S 22$. For the purpose of investigating the resistance of paraffin models, 2-, 3-, 4-, 5-, 6-, 8-, 14 and 20-foot wood planks, each coated with paraffin, were tested at various draughts. With four planks having the lengths of 6 feet and above, it was found that $n$ is independent of the draught, and $x$ is of the speed, and the nature of the resistance is precisely the same as in the case of the lacquered and painted surfaces. The mean value of $15 n$ 's obtained from the four lengths above mentioned was 1.895 (Fig. $54_{\mathfrak{a}}$, Plate IX), and as the final mean of $n 1.90$ was taken. The value of $x$ was found to be exactly the same as the painted surface. The final mean value of 320 $K_{2}$ 's for the four lengths above mentioned was 0.01008 (Fig. 54 $4_{\mathrm{b}}$, Plate IX) which may be taken as practically equal to 0.01004 of the painted surface. But planks having the lengths of 5 feet and under were made thicker, and with them an entirely different aspect of the resistance was observed, i.e., $R_{f}$ to base $d$ curves assumed practically straight lines generally in the same way as in the case of other planks, but these straight lines met no longer at a point on the base line, and although $x$-values at the lowest speed were practically the same as those of the painted surface, they gradually decreased with the increase of the speed, at a greater rate with a greater thickness in proportion to the length of the plank. For instance, with the 2-, 3-, 4- and 5-foot planks, at $120 \mathrm{ft}$. per min., $x$-values were $0.52,0.49,0.46$ and 0.43 inch respectively, but at $560 \mathrm{ft}$. per min. they. decreased to $0.23,0.25,0.36$ and 0.34 respectively. Also $n$-value was found to increase with the draught, and at the minimum draught it was found to be 1.86 to 1.90 , and at the maximum draught to be 1.93 to 1.96 . In the present series of experi- 
ments, an adoption of wood planks for short lengths, with their thickness imprudently increased to stiffen them may have induced a resistance other than the friction. Similar behaviour was also observed with thick varnished planks of 1 to 5 feet in length. The justice of attributing the source of this behaviour to the thickness of plank and the injustice of taking resistance to base $d$ curves as straight lines were verified by the experiments of planks of varying thicknesses, which will be described later on.

In the present series of experiments no critical speed was observed at all, the reason for which appears to be due to the roughness of the surface, and to the greater thickness.

§23. 5- and 8-foot bright brass plates were tested at 6-inch draught. As the result, $n=1.879$ was obtained, but taking it as 1.90 , and assuming $x$-value to be equal to that of the lacquered plate, as the mean value of $K_{2} 0.00958$ was obtained, i.e., in comparing with 0.00974 of the lacquered plate, the resistance is smaller by 1.6 per cent..

$\S 24$. In an actual ship and its model, generally there is a certain amount of cut-up portion at the fore and aft ends of the keel. In order to find the effect of this cut-up on the resistance, the frictional resistance and the edge effect of rectangular planks with a cut-up at the lower edge were measured.

For this purpose, a sufficiently thin 8-foot varnished plank of a rectangular shape was used as a parent plank, cutting away the one end at the lower part to several triangular shapes (Fig. 62, Plate IX), and was tested at various draughts with the cut-up end at forward or at aft, giving always a complete immersion to the cut-up portion.

From the results the following facts may be observed:

(a) In all cases, $R_{f}$ to base $S$ curves (Figs. $55_{\mathfrak{a}}$ to $61_{\mathrm{a}}$, Plate IX) assumed straight lines, and met at a point on the base line in a similar manner as $R_{f}$ to base $d$ curves of rectangular planks. The distance $z$ from the origin to this point is independent of the speed, and it is the edge effect corresponding to $2 L x$ of the rectangular plank.

(b) As will be observed from Fig. 64, Plate IX, $z$ is independent of the height of cut-up, also of the existence of cut-up at the fore end of the plank, and is closely related to the length of cut-up at the aft end of the plank. The quotients obtained by dividing $z$ by $2 L^{\prime}$, where $L^{\prime}=L$-(Length of the aft cut-up portion of the edge), are 0.46 to 0.47 inch in all cases and their mean value becomes 0.46 inch, i.e., the edge effect of the 8 -foot rectangular plank or the parent plank. Therefore, the following relation will be established:

$$
z=2 L^{\prime} x
$$


where $x$ is the edge effect of the rectangular plank.

It follows that if the aft end of the planks is cut up, the augmentation of surface will be reduced in proportion to the length of cut-up, and the cut-up of the fore end has no effect on $2 L^{\prime} x$. From this fact, it may be seen that the origin of the edge effect is at or near the fore end of the plank.

(c) Throughout the experiments, $n$ may be regarded as a constant independent of the draught (Figs. $55_{b}-61_{b}$, Plate IX) and the length of cut-up, and though its mean value obtained was 1.902 (Fig. 63, Plate IX), it was taken to be 1.90 .

Putting $L^{\prime}$ in place of $L$ in the equation (9) in $\S 18$, Part I, $K_{2}$ was found to be a constant, and the mean value 0.00980 for the aft-end cut-up (Fig. 66, plate IX), and $\mathbf{0 . 0 0 9 8 4}$ for the fore-end cut-up (Fig. 65, Plate IX) and as the weighted mean of the two, 0.00981 was obtained.

Therefore,

$$
\begin{aligned}
R_{f} & =K_{1} S\left\{1+L^{\prime} x /(6 S)\right\} V_{K}^{1.90} \rho \nu^{0.165} \ldots \ldots \ldots \ldots \ldots(10) \\
\left(R_{f}\right)_{55^{\circ \mathrm{F}} .} & =K_{2} S\left\{1+L^{\prime} x /(6 S)\right\} V_{K}^{1.90} \ldots \ldots \ldots \ldots \ldots \ldots \ldots(11)
\end{aligned}
$$

The above equations (10) and (11) will be taken as a general form of $R_{f}$ applicable to thin smooth planks of a rectangular shape in which case $L^{\prime}$ becomes $L$ or having a cutup over edge.

\section{Variation of the Resistance in Increasing the Thickness of Planks.}

§25. As already described, even with smooth planks, when they are not thin, $n$ depends on the draught, and $x$ on the speed, this may be considered to be due to the effect of the thickness, therefore there is a necessity of confirming an influence of the thickness on the resistance. Again, even with thin planks in which $n$ and $x$ are constant, a small water-surface disturbance such as ripples or wavelets during experiments is inevitable, which naturally brings up some doubts on the measured resistance regarding its true indication of the pure frictional resistance. An attempt was made to prepare thinner planks, but it was found to be almost impossible to prepare sufficiently thin planks and to carry out experiments to any satisfactory end, therefore a counter measure was taken. That is to say, if an influence of the thickness was investigated by gradually increasing the thickness, then on one hand, an effect of the thickness will be ascertained, which ultimately may be used in the application of plank results to a model, and on the other hand, the cases of ideal thin planks may be deduced from these results. Therefore, the experiments were carried out to this effect. 
Planks chosen were of a varnished surface, and of five different lengths of 4, 5, 8, 14 and 20 feet, and they were quite similar in thickness and form, i.e., generally nine different thicknesses of (a), (b), (c), (d), (e), (f), (g), (h) and (i), were given to each length, and those of the same mark were all of a similar form. These were tested at similar draughts, also at various draughts with (thickness) $/ L 0.00205,0.00263,0.00328$, $0.00525,0.00656,0.00984,0.0131,0.0263$ and 0.0525 respectively.

For instance, with the 5 -foot planks, there are (c), (d), (e), (f), (g), (h) and (i) thicknesses, and the form of each plank is shown in Plate $\mathrm{X}$. All of these were tested at 2-, 3- and 7-inch draughts, and the results obtained are shown in $R$ to base $d$ and $n$ to base $d$ curves for several constant speeds (Figs. $67_{\mathrm{a}}$ and $67_{\mathrm{b}}$ to $72_{\mathrm{a}}$ and $72_{\mathrm{b}}$, Plate $\mathrm{X}$ ), $R$ being the total measured resistance. The results may be summed up as:

With (c) (0.197 inch) and (d) (0.315 inch), $n$ is independent of the draught, and its mean values are 1.900 and 1.895 respectively, $x$ is also independent of the speed, and its value is 0.66 inch. But with (e) (0.394 inch) $R$ to base $d$ curves are practically straight lines, and at 2-inch draught $n$ is 1.85 and at 7 -inch draught $n$ is 1.91 , thus it increases with the increase of the draught, $x$ at the lowest speed is about $0.66 \mathrm{inch}$, and decreases with the increase of the speed, and at the highest speed it is only 0.55 inch. With an increasing thickness as ( $f$ ) (0.591 inch), ( $g$ ) (0.787 inch), the above-mentioned tendency of the change of $n$ and $x$ is conspicuous, $n$ increasing with the draught from 1.78 to 1.88 with (f) and from 1.72 to 1.83 with $(\mathrm{g}), x$ decreasing with the increase of the speed from 0.66 to 0.34 inch with (f) and from 0.66 to 0.19 inch with (g). At (h) (1.575 inch) and (i) (3.150 inch), $\log R$ to base $\log V$ curves are no longer straight lines, and $R$ to base $d$ curves assume real curved lines. Particularly with (i), though it was tested at various draughts of $1,2,3,5$ and 7 inches, $x$ value was not obtainable by extension. As the result of careful study of these changes of $n$ and $x$ accompanying the change of the thickness, it may be seen that, at (e), (f) and (g), since $n$ changes with the draught, the recognition of the apparent straight lines assumed by $R$ to base $d$ curves as straight lines is in itself unreasonable, therefore such procedure to find $x$ by an extension and to arrive at the conclusion that $x$ decreases with the increase of the speed is no more than a superficial judgment. Indeed the true aspect of the edge effect in such cases will not be found merely from the drawings, therefore further investigations will be necessary. In this connection, further comments will be made in Appendix II.

From the above results, if $R$ to base thickness curves for several constant draughts and constant speeds (Figs. $73_{\mathrm{a}}, 73_{\mathrm{b}}, 73_{\mathrm{c}}$, Plate $\mathrm{X}$ ), and $n$ to base thickness curves for several constant draughts (Fig. 74, Plate $\mathrm{X}$ ) and $x$ to base thickness curves for several 
constant speeds (Fig. 75, Plate $\mathrm{X}$ ) on the assumption that $x$ changes with the speed, were plotted, a respective relation of thickness to $R, n$ and $x$ will be found. With the 5 -foot planks, it was found from the above curves that at the thickness (d) (0.315 inch) and below, $R, n$ and $x$ are constant, and above that thickness $R$ is increasing, and $n$ and $x$ are decreasing. Therefore, (d) and thinner planks may be considered as a thin planks, and may be practically ssumed as an ideal thin plank, and thicker planks may be said to contain the form resistnce or other resistances. And (d) corresponds to $0.00525 L$.

The results of other four lengths are exactly the same as will be seen from $\log R$ to base $\log V$ curves with the 4-foot plank (Fig. 76, Plate $\mathrm{X}$ ) and $R$ to base thickness curves with the 4-, 8-, 14- and 20 -foot planks (Figs. $79_{\mathrm{a}}$ and $79_{\mathrm{b}}$ to $82_{\mathrm{a}}$ and $82_{\mathrm{b}}$, Plate XI). In each case (d) $(0.00525 \mathrm{~L})$ is the limiting thickness, i.e., the limiting thickness is proportional to the length. Moreover, with a greater thickness than (d), $n$ almost equally decreases for all the planks with the increase of (thickness) $/ L$ at a given $d / L$ and with the decrease of $d / L$ at a given (thickness) $/ L$ as shown in $n$ to base (thickness) $/ L$ curves at several constant $d / L$ 's (Fig. 85, Plate XI). Therefore, from the results of these planks or by their extension, the total resistance of planks thinner than $0.00525 \mathrm{~L}$ or practically $1 / 200 L$, provided all the ends and edge of the plank are finished to sharp knife-edges with fair tapers, may be taken to be only the frictional resistance, and that of the thicker planks may be taken to include other additional resistance. According to the study described in Appendix II, the frictional resistance of the thicker planks may be expressed as follows:

$$
R_{f}=K_{1} S\left\{1+\left(L^{\prime}+C L\right) x /(6 S)\right\} V_{K}^{1.90} \rho \nu^{0.165}
$$

where $C$ is a factor which may be called the coefficient of the scale effect.

With thickness (d) and under in each length, $x$ has the same value as in lacquered planks, and the mean value of $n$ is found to be independent of the length as shown in $n$ to base length curve (Fig. 77, Plate $\mathrm{X}$ ) with the value 1.900, 1.898, 1.898, 1.895 and 1.895 respectively and the final mean of $40 \mathrm{n}$ 's 1.898 . Therefore, taking it as 1.90 to find $K_{2}$, the latter is also found to be independent of the length as shown in $K_{2}$ to base length curve (Fig. 78, Plate X), with the value 0.00975, 0.00976, 0.01002, 0.00974 and 0.00984 respectively and the final mean of $805 K_{2}$ 's $0.00984\left(K_{1}=0.0324\right)$, i.e., it is almost the same as that obtained in Part I and may be taken as the resistance coefficient of varnished planks. Besides thick planks, descriptions on some experiments with other forms and some comments on the edge effect in general will be found in Appendix III. 
Scale Effect and Frictional Resistance of Ship-modls.

$\S 26$. To find the frictional resistance of a model, a start should be made on the amount obtained by deducting the residuary resistance from the total resistance of a similar model at the corresponding speed, free from the wall and bottom effect of the experimental Tank. The wall and bottom effect was discussed theoretically and experimentally in the Tank Committee's Report. ${ }^{(17)}$ As it bears a close relation to the skin friction of models, also in general, to the reliability of the small Tank, a brief comment. on the subject will be found in Appendix IV.

Next the scale effect on the frictional resistance of ship-models, must be attended to, and the following assumptions were made:

The edge effect the same as the thin plank of the same length is assumed to exist also in a model, and in addition, the scale effect of a model is taken as $C$ times that edge effect. Though $C$ is variable with the form of the model, it may be taken as constant. between similar models at a similar draught. Further, if the net frictional resistance of the model is assumed to be the same as that of the plank having the same surface area, then for models, the same formula (12) in § 25 will hold good, i.e.,

$$
R_{f}=K_{1} S\left\{1+\left(L^{\prime}+C L\right) x /(6 S)\right\} V_{K^{1.90}} \rho \nu^{0.165} \text {. }
$$

Let the dimensional ratio of the larger model to the small model be $\lambda$ for a pair of similar models, capital letters stand for the larger, and small letters for the small model, also suffixes $T$ and $t$ for their respective temperatures,

then $\quad R=\left(R_{w}\right)_{T}+\left(R_{f}\right)_{T}=\left(R_{w}\right)_{T}+K_{1} S\left\{1+\left(L^{\prime}+C L\right) X /(6 S)\right\} V_{K}{ }^{1.90}\left(\rho \nu^{0.165}\right)_{T}$, $r=\left(r_{w}\right)_{t}+\left(r_{f}\right)_{t}=\left(r_{w}\right)_{t}+k_{1} s\left\{1+\left(l^{\prime}+C l\right) x /(6 s)\right\} v_{k}^{1.90}\left(\rho \nu^{0.165}\right)_{t}$.

If we assume $\rho_{t}=\rho_{T}$ at the practical range of the temperature, $\lambda^{3}\left(r_{w}\right)_{t}=\left(R_{w}\right)_{T}$ at corresponding speeds. Calling $t$ and $T$ for $\left(\rho \nu^{0.165}\right)_{t}$ and $\left(\rho \nu^{0.165}\right)_{T}$ respectively,

$$
\begin{aligned}
\lambda^{3} r-R & =\lambda^{3}\left(r_{f}\right)_{t}-\left(R_{f}\right)_{T} \\
& =\lambda^{3} k_{1} s\left\{1+\left(l^{\prime}+C l\right) x /(6 s)\right\} v_{k}^{1.90} t-K_{1} S\left\{1+\left(L^{\prime}+C L\right) X /\left(6 S^{\prime}\right)\right\} V_{K^{1.90}} T .
\end{aligned}
$$

Then,

$$
\frac{\left(\lambda^{3} r-R\right) /\left(S V_{\mathrm{K}}^{1.90}\right)-\left(k_{1} \lambda^{0.05}-K_{1} T\right)}{k_{1} \lambda^{1.05} x t-K_{1} X T}=\frac{L^{\prime}+C L}{6 S} \ldots \ldots \text { (13). }
$$

If the surfaces of similar models are of the same nature, $k_{1}=K_{1}$ and if the temperature is constant, $t=T$.

Thus, if the total resistance $r$ and $R$ were determined, $C$ will be obtained from (13).

To examine the truth of this formula (13), firstly it is necessary to see, $\left(\lambda^{3} r-R\right) /$ $\left(S V_{K}{ }^{1.90}\right.$ ) being only terms related to $V$, whether it is independent of $V$ or not. If 
$\left(\lambda^{3} r-R\right) /\left(S V_{K}{ }^{1.90}\right)$ to base $V$ curve was of such a nature as to be recognized as approximately a straight line parallel to the base line, then $C$ which is practically independent of the speed would be obtained. This may be taken as a first proof of the formula (13).

Secondly, granted that the formula is true, then $C$ obtained from the two models above mentioned, and $C$ obtained by the same manner, between one of the two models above mentioned, and another similar model of a different size, must be equal. And if a number of $C$ thus obtained from a number of similar models of different sizes, have a constant value, it will serve as a further proof of the formula. In short, if these two proofs were established, then the formula might be accepted as true.

Fortunately, the experimental results of eleven similar models of a merchant ship form ranging from 5 feet to $\mathbf{1 7 . 4 6}$ feet in length tested at a similar draught at the Mitsubishi Tank in 1918-1919 as shown in Table V, were placed at the disposal of the author by the kind permission of Dr. Motora, the director of the Mitsubishi Dockyard, Nagasaki. Of these, the largest model No. 339 was compared with ten other models, and the formula was appiied. $R$ and $r$ to base $V$ curves for models Nos. 329, 335, 338 and 339 , and $\left(\lambda^{3} r-R\right) /\left(S V_{K^{1.90}}\right)$ to base $V$ curves for Nos. 329,335 and 338 are shown in Fig. 89, Plate XII, from which it will be observed that there is a fluctuation in the values obtained in relation to the speed, however they may be generally recognized as parallel to the base line and independent of the speed. Therefore, by finding the mean value of each model, $C$-value for each of ten models referred to the largest model was obtained. The greatest $v / \sqrt{l}$ used in this series was 0.93 which corresponds to 0.38 $\sqrt{(B D) /(b l})$ of the largest model, therefore there is no wall and bottom effect (Appendix IV) whatever. In plotting the mean value of $\left(\lambda^{3} r-R\right) /\left(S V_{\mathrm{K}}{ }^{1.90}\right)$ for each of ten models on its length-base as shown in Fig. 90, Plate XII, a clean fair curve decreasing with the increase of the length was obtained, and also in plotting $C$ on the length-base as shown in the same figure, a straight line parallel to the base line was obtained, therefore $C$ is a constant for all models. Therefore, the proposed formula may be acknowledged to have worked exceedingly well with this series of similar models.

Again, the Teishinsho (Ministry of Communications) Tank staff was good enough to place at the author's disposal their experimental results of similar models (tested in 1932) Nos. 3, 4 and 5 of the length 4.876, 9.752 and 14.63 feet respectively, each at three conditions of deep, medium and light loads as shown in Table VI. Following the same step as with the Mitsubishi models, the formula was applied to Nos. 5 and 4 models in reference to the largest model No. 3. In this series, it was found that the greatest $v / \sqrt{l}$ is 1.28 which corresponds to $0.27 \sqrt{(B D) /(b l)}$ of the largest model, 
therefore by Appendix IV there is no wall or bottom effect. The aspect of $\left(\lambda^{3}-R\right) /$ $\left(S V_{K}{ }^{1.90}\right)$ for $V$, is generally the same as that of the Mitsubishi models. Three examples together with $R$ and $r$ for $V$ are shown in Fig. 91, Plate XII. For each of three loaded conditions, $C_{5-3}$ and $C_{4-3}$ were obtained, and it was observed that there is not much difference between $C_{5-3}$ and $C_{4-3}$ at the same loaded condition, and also either $C_{5-3}$ 's or $C_{4-3}$ 's at different conditions distinctly increase with the draught or the displacement.

$d / L$ to base $C_{5-3}, d / L-C_{4-3}$ and $\Delta /\left(\frac{1}{100} L\right)^{3}$ to base $C_{5-3}, \Delta /\left(\frac{1}{100} L\right)^{3}$ to base $C_{4-3}$ curves are shown in Fig. 92, Plate XII, $\Delta$ being the displacement in tons in sea-water. Though these curves are curved lines increasing with the draught or the displacement, they pass very nicely through the origin of the co-ordinates, and $d / \dot{L}$ to base $C_{\text {mean }}$ and $\Delta /\left(\frac{1}{100}\right) L^{3}$ to base $C_{\text {mean }}$ curves are practically straight lines passing through the origin, i.e., approximately

or

$$
\begin{array}{lll}
C=C_{1} d / L & \text { where } & C_{1}=40, \\
C=C_{2} \Delta /\left(\frac{1}{100} L\right)^{3} & \text { where } & C_{2}=0.015 .
\end{array}
$$

Thus, it will be seen that either in Mitsubishi models or in Teishinsho models, a series of similar models at a similar draught has a common coefficient of scale effect $C$, and further, in Teishinsho models, $C$ is practically proportional to $d / L$ or $\Delta /\left(\frac{1}{100} L\right)^{3}$.

$\S 27$. Now, a comparison between the models experimented with in the small Tank, and the similar models in the Mitsubishi Tank will be described, and as a premise, by virtue of the experiments of the six similar models described in Appendix IV, the accuracy of these two Tanks is recognized to be equal, so long as they are not affected by the wall or bottom effect.

Models used in the small Tank were principally 5-foot models, although 4- and 6 -foot models were occasionally used, and those of the Mitsubishi Tank were generally of 12 to 17 feet and were similar models. The models were of almost all kinds of naval ships except submarines, and were seventeen in number. In general, they were of two similar models, though sometimes they were of three or four similar models, and in all cases, they were tested at three conditions, deep, normal and light, and the total number of $C$ 's obtained was more than 130 , and $d / L$ ranged between 0.0205 and 0.0559 , and $\Delta /\left(\frac{1}{100} L\right)^{3}$ between 23 and 148 .

Of these, three examples, each dealing with similar models at the draughts, moro than three conditions are shown by $d / L$ to base $C$ and $\Delta /\left(\frac{1}{100} L\right)^{3}$ to base $C$ curves (Fig. 
93, Plate XII), of which one is an example where the fluctuation of $C$ is small, and the other, where it is great. Judging from the results of all models, it was found that they are very similar to the cases of the Teishinsho- and Mitsubishi-models, i.e., for similar models at a similar draught, $C$ is a constant; with a change in draught $C$ distinctly increases with the draught or displacement and more or less approaches zero when the draught is very small, and with a change in the form of model is a function of the form, and generally small in a fine form and large in a full form.

As the results of several trials, it was found to be most convenient to take $C$ as the function of $\Delta /\left(\frac{1}{100} L\right)^{3}$ for various forms of models, including the Mitsubishiand Teishinsho-models. That is to say, if $C$ is plotted on the $\Delta /\left(\frac{1}{100} L\right)^{3}$-base, it may be approximately represented by an ascending curve passing through the origin as shown in Fig. 94, Plate XII. $C$ becomes zero in thin planks, $\Delta /\left(\frac{1}{100} L\right)^{3}$ being very small. $\boldsymbol{C}$ will be a function of various elements of forms and shapes of bottom especially at a forward section, etc.. The curve represents only a general tendency of the variation of $C$ with $\Delta /\left(\frac{1}{100} L\right)^{3}$. However, to take $C$ as constant for similar models at a similar draught may be said fairly to be established, and for models

$$
\begin{aligned}
R_{f} & =K_{1} S\left\{1+\left(L^{\prime}+C L\right) x /(6 S)\right\} V_{K^{1.90}} \rho \nu^{0.165} \\
& =K_{2} S\left\{1+\left(L^{\prime}+C L\right) x /(6 S)\right\} V_{K^{1.90}} \ldots \ldots
\end{aligned}
$$

where $C$ is to be determined from a series of similar models at a similar draught, or from the above curve when there are no means of having similar models.

From the investigation of similar models made in the foregoing paragraph, the augmentation of the surface $2\left(L^{\prime}+C L\right) x$ for any model with a change in draught may be considered to be

$$
2\left\{L^{\prime}+C_{1}(d / L) L\right\} x \quad \text { or } \quad 2\left(L^{\prime}+C_{1} d\right) x \text { approximately, }
$$

where $C_{1}$ is very roughly a constant for one model.

Then the aggregate scale effect of a model may be considered to consist of the sum of the following two terms:

(1) $2 L^{\prime} x$, the same as that of the edge effect of thin planks of the same length.

(2) $2 C_{1} d x$, existing only in models, $C_{1} d$ being used instead of $L^{\prime}$ in $2 L^{\prime} x$ of (1).

That is to say, since with models, there is not only the horizontal edge effect proper to thin planks, but an extra edge effect which may be called a vertical edge effect in a three-dimensional flow, and while (1) is independent of the form of the model, (2) 
is dependent, also (1) being essentially a part of $R_{f}$ of planks, the scale effect peculiar to models only, exists in (2).

$\S 28$. From the formulae (14) and (15) all the models of about 26 feet and under in length will be subjected to a scale effect to such a degree that the shorter the model and the greater the $\Delta /\left(\frac{1}{100} L\right)^{3}$, the greater will be its effect. Therefore, whatever formula for skin friction may be used, if a small model is used, and $\Delta /\left(\frac{1}{100} L\right)^{3}$ is not specially taken into account, it is quite natural that some errors are inevitable in the estimation of the residuary resistance. For instance, with a full and deep model, the residuary resistance obtained by deducting $R_{f}$ from its total measured resistance would be in excess of its true value, and consequently, E.H.P. of the actual ship will be overestimated with an apparently good propulsive efficiency as the result. The scale effects of models of various types of ships represented by three different model-lengths of 5 , 12, and 20 feet are shown in Table IX using $C$ obtained from the curve (Fig. 94, Plate $\mathrm{XII}$ ). It will be observed that against the aggregate scale effect 18.9 per cent. of a 5 -foot paraffin destroyer model in normal condition, that of a paraffin cargo-boat model of the same length in deep condition is as much as 26.4 per cent., and with 12-foot models, they are 4.1 per cent. and 5.7 per cent. respectively, but with 20 -foot models, there is a remarkable decrease, so much so that even that of the latter is less than 1 per cent..

A reduction of the resistance due to a model form having less scale effect is only peculiar to models, and bears no relation to actual ships, therefore for a study of new form, it is necessary that a scale effect must be ascertained first. On the other hand, edges or sharp corners in the longitudinal direction in a model, for instance, edges of bilge keel, bar keel, or possibly the landing edges of the outside plating, will introduce a new edge effect, and thereby will add a resistance other than that experienced by a ship, or there may be some other forms which introduce a negative resistance. The greatest care should be taken in the extension of the model results to actual ships.

Truly the above is no more than the author's inductive reasoning from the results of similar models on his hands. It is hoped that the problem will be taken up seriously and perfected with many series of a large number of similar models not affected with wall or bottom effect, until then, the determination of scale effect by testing at least two similar models or better with three similar models would be the only reliable method in applying the results to actual ships.

$\S 29$. An existence of the critical speed observed with 4 -foot and short planks bears an important relation to the use of small models. Take, for short and long models, 
$r_{f}=k s v^{1.90+a}$ and $R_{f}=K S V^{1.90}$ at a constant temperature respectively.

At corresponding speeds, $\lambda^{3} r-R=\lambda^{3} k s v^{1.90+a}-K S V^{1.90}$,

$$
\left(\lambda^{3} r-R\right) /\left(S V^{1.90}\right)+K=k \lambda^{0.05-\frac{1}{2} a} V^{a} \text {. }
$$

Therefore, if $\left(\lambda^{3} r-R\right) /\left(S V^{1.90}\right)$ to base $V$ curve is drawn, then, when the curve is parallel to the base line, $a=0$, and when the curve is ascending as $V$ increases, $a>0$.

Now, as one example, a case of 4- and 2-foot varnished models against a 6 -foot varnished model of the ex-destroyer "Yudachi" is shown in Figs. 95 and 96, Plate XII, in which it will be seen that the curve is of an ascending nature up to a certain speed, and above that speed it suddenly changes to assume a parallel line to the base line, and the speed at this changing point in the curve will be the second critical speed $V_{2 C}$, and at smaller speeds, $a \fallingdotseq 0.2$ and $n \fallingdotseq 2.1 . \quad V_{2 C}$ has a tendency to occur at a higher speed with the decrease of the draught. In general, the similarity of values between two models is the same as in the case of 4 - and 2-foot planks, and further, there is not much difference between models at the light condition and planks, all being about 360 ft. per min. or thereabout at $68^{\circ} \mathrm{F}$.

Therefore, when 4-foot and shorter models are used, then in the process of finding $C$ the existence of $V_{2 C}$ will be naturally detected. Of six of the 4-foot models, those in which the existence of $V_{2 C}$ was detected, were only the "Yudachi"- and 4-foot gunboat-models. In all, the case of the "Yudachi"'-model was most conspicuous. The exact form of model and exact condition in which $V_{2 C}$ will exist, have not yet been investigated, therefore are as yet ambiguous. In short, the fact that, in connection with the critical speed, there is also a common quality between models and planks of 4 feet and under in length, may be taken to suggest an important bearing in extending the plank results to models.

Further, it is important to note that, in order to maintain the coefficient $C$ for models shorter than 5 feet to be common with similar models of 5 feet and above, the edge effect $x$ should be decreased from that of planks. Only the results will be given here, i.e., with 5-, 4-, 3- and 2-foot lengths, $x$ of models with varnished or lacquered surfaces are $0.66,0.56,0.45$ and 0.35 inch against $0.66,0.73,0.81$ and 0.95 inch of planks of the same surface. No experiments were made; however it may be conceived that planks of other natures of surface having a different edge effect should be respectively dealt with in equal proportion.

\section{Conclusion.}

$\S 30$. Judging from the effect of temperature and sea-water discussed in Part I, 
and those investigations described in Part II, the new formula deduced by considering the total resistance for the speeds above the second or higher critical speed of smooth planks of 4 feet to 26 feet in length, under $1 / 200 \mathrm{~L}$ in thiekness and having the knifeedged ends and edge to be the frictional resistance, is

$$
\begin{gathered}
R_{f}=K_{1} S\left(1+\frac{L^{\prime} x}{6 S}\right) V_{K^{1.90}}^{1.9} \nu^{0.165}, \\
\left(R_{f}\right)_{55^{\circ} \mathrm{F} .}=K_{2} S\left(1+\frac{L^{\prime} x}{6 S}\right) V_{K^{1.90}},
\end{gathered}
$$

\begin{tabular}{|c|c|c|c|c|c|c|c|c|c|c|}
\hline Nature of surface & \multicolumn{3}{|c|}{$\begin{array}{l}K_{1} \text { for fresh water } \\
\text { and sea-water }\end{array}$} & \multicolumn{3}{|c|}{$\begin{array}{c}K_{2} \text { for } \\
\text { fresh water }\end{array}$} & \multicolumn{4}{|c|}{$\begin{array}{l}\boldsymbol{K}_{2} \text { for } \\
\text { sea-water }\end{array}$} \\
\hline (1) Bright brass plate & \multicolumn{3}{|c|}{0.0316} & \multicolumn{3}{|c|}{0.00958} & \multicolumn{4}{|c|}{0.00986} \\
\hline (2) Lacquered surface & \multicolumn{3}{|c|}{0.0321} & \multicolumn{3}{|c|}{0.00974} & \multicolumn{4}{|c|}{0.01002} \\
\hline (3) Varnished surface & \multicolumn{3}{|c|}{0.0324} & \multicolumn{3}{|c|}{0.00984} & \multicolumn{4}{|c|}{0.01013} \\
\hline (4) Painted surface & \multicolumn{3}{|c|}{0.0331} & \multicolumn{3}{|c|}{0.01004} & \multicolumn{4}{|c|}{0.01033} \\
\hline (5) Paraffin surface & \multicolumn{3}{|c|}{0.0332} & \multicolumn{3}{|c|}{0.01008} & \multicolumn{4}{|c|}{0.01037} \\
\hline Length, feet & 1 & 2 & 3 & 4 & 5 & 6 & 8 & 14 & 20 & 26 \\
\hline$(x$ (inch) for $(1),(2),(3) \ldots$ & 0.95 & 0.88 & 0.81 & 0.73 & 0.66 & 0.59 & 0.46 & 0.18 & 0.05 & 0 \\
\hline $\begin{array}{l}\text { ditto for models only } . . . \\
\text { shorter than } 5 \text { feet }\end{array}$ & & 0.35 & 0.45 & 0.56 & 0.66 & & & & & \\
\hline$(x$ (inch) for $(4),(5) \ldots .$. & & 0.52 & 0.49 & 0.46 & 0.43 & 0.40 & 0.34 & 0.17 & 0.04 & 0 \\
\hline
\end{tabular}

where

Thus $R_{f}$ is composed of two essential parts:

(1) The net frictional resistance which is proportional to $S$, and independent of other dimensions, and (2) the augmented frictional resistance founded on the edge effect, which exists only in short planks, and is supposed to vanish in planks longer than 26 feet.

Therefore, the net resistance in short planks excluding the edge effect, and the total resistance in 26-foot and longer planks will be

$$
R_{f}=K_{1} S V_{K}^{1.90} \rho \nu^{0.165} \quad \text { or } \quad\left(R_{f}\right)_{55^{\circ} \mathrm{F} .}=K_{2} S V_{K}^{1.90},
$$

and the frictional resistance per unit area will be independent of the length, and constant.

With rectangular planks, shorter than 26 feet having $\left(R_{f} / S\right) \infty(1+x / d), R_{f}$ per unit area will have a larger variation according to the draught, with the limiting value $R_{f} \infty 2 L x$ when the draught is very small, and $R_{f} / S=$ constant as in long planks, when the draught is very large. With intermediate draughts, its variation with the length will be
(a) $x / d$ constant,
$R_{f} / S$ constant to the length,
(b) $d$ constant,
$R_{f} / \mathrm{S}$ decreases as the length increases,
(c) $d / L$ seonstant,
$R_{f} / S$ decreases as the length increases.

In (b) and (c), as shown in Table VIII, the smaller $d$ and $d / L$, the larger will be the 
rate of the reduction of the frictional resistance per unit area as the length inereases.

Following Froude's method that the frictional resistance of ship-models is equivalent to that of planks of the same length and the same surface area but assuming the existence of an additional resistance which is a certain function of the edge effect, or the scale effect, the author has made a study of the measured resistance of similar models, and has ascertained that the frictional resistance of any model may be expressed by

and

$$
\begin{aligned}
R_{f} & =K_{1} S\left\{1+\left(L^{\prime}+C L\right) x /(6 S)\right\} V_{K}^{1.90} \rho \nu^{0.165}, \\
\left(R_{f}\right)_{55^{\circ} \mathrm{F} .} & =K_{2} S\left\{1+\left(L^{\prime}+C L\right) x /(6 S)\right\} V_{K}^{1.90} .
\end{aligned}
$$

$\mathrm{He}$ also found that $R_{f}$ obtained by this expression together with the residuary resistance obtained by the law of comparison satisfied not only the measured resistance of similar models, but also arrived at the result that even with 4- and 5-foot models in which the scale effect is very large, their temperature effect is exactly the same as that of planks. As a matter of course, there should be no difference between models and planks in the temperature effect on the frictional resistance, but any error in the estimate of the frictional resistance of models would prevent taking this natural course as described in $\S 11$, Part I.

A comparison of the experimental results obtained by Froude, ${ }^{(18)}$ and those obtained by Kempf ${ }^{(19)}$ and Gebers ${ }^{(20)}$ and the values obtained from the new formula are shown in Table IX.

Froude, stating in his second paper "At a length of 50 feet, the decrease (with increasing length) of the friction per square foot of every additional length is so small that it will make no very great difference in our estimate of the total resistance of a surface three hundred feet long, whether we assume such decrease to continue at the same rate throughout the last two hundred and fifty feet of the surface, or to cease entirely after fifty feet, while it is in effect certain that the truth must lie somewhere between these two assumptions," assumed each length of the length beyond the first 50 feet experienced the same resistance as the last foot of the 50 -foot plank.

Also Kempf has stated that the total resistance increased proportional to the length from the shortest 7.3 metres to the longest 61.75 metres.

But Gebers maintained, from his experimental results, a view of following the

(18) Second Report, Ann. Rep. Brit. Assoc., 1874.

(19) W. R. H., Okt. 22, 1924.

(20) loc. cit. 
formula $R_{f}=\rho S V^{2}(V L / \nu)^{N}$, and obtaining $N=-0.125$, established the form $R_{f} / S \infty L^{-0.125}$ without the confirmation of the variation of the resistance with the change of $\nu$. However, the mean value of the ratios of the measured resistance per unit area of the 10metre plank to the 7.5-metre plank is actually very near to a unity, being 0.991 . The new formula gives 0.999 whilst the $L^{-0.125}$-formula gives 0.964 .

Therefore, in each of the experiments of Froude and Kempf and even with that of Gebers, when a certain length is reached, then above that length the measured resistance per unit area approaches to a constant, and though it decreases with the increase of the length, its indication is exceedingly small.

Among other investigations, in 1915 the Froude Tank ${ }^{(21)}$ proposed the form $R_{f}=$ $\rho A V^{2}\{(V L / \nu)\}^{-0.138}$, this was probably established from various plank results and with a view that the results are in conformity with this form. On the other hand, Stanton ${ }^{(22)}$ has, in his experiment of a 16-foot thin plate in wind tunnel ascertained the result that the total resistance is proportional to the length.

After all, contrary to the author's original aim of obtaining a correct form of the generally accepted modern form $R_{f}=\rho S V^{2} f(V L / \nu)$ by a faithful analysis of the experimental results obtained in the small Tank, it has resulted in the formation of one inductive formula. However, since the final aim of the investigations is, needless to say, to arrive at the proper estimation of the frictional resistance by a suitable application of experimental results to actual ships, a working of the new formula in its application to the experimental results of a plank ship, a destroyer, and a tug-boat, etc., also to Froude's classical experimental results of H.M.S. "Greyhound" as mentioned in the Introduction will be hereafter described, in the second paper. ${ }^{(23)}$

In concluding this paper, the author expresses his greatest gratitude to all members of the experimental Tank staff of the Naval Technical Research Department for their cooperation in carrying out the experiments and investigations much above the author's expectation. The author has also to express his thanks to the late Dr. N. Yamamoto, to whom he is much indebted in preparing this paper.

\section{Appendix I.}

\section{The Critical Speed of Short Planks.}

An observation of the critical speed with thin smooth planks of.4 feet and under

(21) "Skin Friction Committee's Report," Trans. I.N.A., 1925.

(22) "The Effect of Length on the Skin Friction of Flat Surface," Trans. I.N.A., 1924.

(23) loc. cit. 
in length has been already referred to here and there in this paper, however in this Appendix it is proposed to submit a brief account of its characteristics. Instances of various planks are shown in Table $X$. As it was ascertained that the critical speed is independent of the draught when the plank is sufficiently thin, a comparative study can be confidently made independent of the draught.

With lacquered planks :

(a) The first or lower critical speed $V_{1 C}$ was not observed with planks of 3 feet and above in length. Even with a 2 -foot plank, it was observed only at $70^{\circ} \mathrm{F}$. and lower temperature, increasing in value with the decrease of temperature, and at $77^{\circ} \mathrm{F}$. and above, it could not be detected on account of an exceedingly low speed. With a 1-foot plank, it was observable at the low temperature. The value of $V_{1 C}$ decreased with the increase of the length, also with the increase of the temperature and $V_{1 C} L / \nu$ mav be considered to be approximately constant as shown in Table $\mathrm{X}$, with $0.49 \times 10^{6}$ as their mean value obtained from eleven experiments.

(b) The second or higher critical speed $V_{2 C}$ was observed with planks of 4 feet and under in length. Its absence with a 1-foot plank appears to be due to the insufficiency of the speed given in the experiments to cause its existence. Probably it would have appeared at about $800 \mathrm{ft}$. per min. Generally speaking, its values are much more irregular than $V_{1 C}$. As will be seen from Table $\mathrm{X}, V_{2 C}$ decreases with the increase of the temperature in the same manner as $V_{1 C}$, but in its relation with the length, although it decreases with the increase of the length in 1- to 3-foot planks as in $V_{1}$, it exhibits a quite contrary character of increasing in the 4-foot plank. $V_{2 C} L / \nu$ for 2 and 3-foot planks at a constant temperature is approximately constant, but considerably increases in the 4-foot plank. This is, of course, due to the above-mentioned sudden increase of $V_{2 C}$ with the 4-foot plank. In its relation to the temperature, differing from $V_{1 C} L / \nu, V_{2 C} L / \nu$ conspicuously increases at higher temperatures in spite of the decrease of $V_{2 C}$.

(c) In the three zones of "Below $V_{1 C}$," "Between $V_{1 C}$ and $V_{2 C}$ " and "Above $V_{2 C}$," $R_{f} \infty V^{n}$ may be recognized with separate $n$-value for the respective zone (Table V).

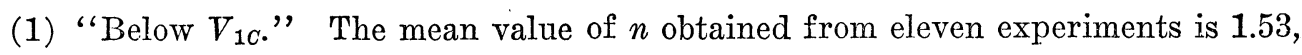
but it has a tendency to decrease with the increase of the length, and with the increase of the temperature.

(2) "Above $V_{2 C} . "$ For all the planks of 2, 3 and 4 feet, $n$-value may be taken as 1.90. The fact that $n$ is independent of the draught, temperature and length, and also the fact that every $n$-value is almost 1.90 and its mean value of 35 cases is 1.904, 
indicate a remarkably steady flow.

(3) "Between $V_{1 C}$ and $V_{2 \sigma}$. " Though $n$-value exceeds 2.00 , and is independent of the temperature except in the ambiguous case of the 1-foot plank, in 2- to 4-foot planks it decreases with the increase of the length, and gradually approaches to 1.90 of "Above $V_{2 C}$," and ultimately there is a complete absence of $V_{2 C}$ in longer planks. Yet, with a smoother brass plate, $V_{2 C}$ is observed with a 5 -foot length. Further, as it will be seen from Fig. 48, Plate VIII, with 3 - and 4-foot planks, the existence of two stream lines could be detected in this zone; one is the extension of "Above $V_{20}$ " zone with $n=1.90$, and the other is that of "Between $V_{1 C}$ and $V_{2 C}$ " zone; and for all the planks, the spots within this range appear to be very irregular which clearly indicates the zone of an unstable flow between two critical speeds.

(d) Speaking of the thickness and the smoothness of planks, a thinner and smoother plank affords more opportunity for both $V_{1 C}$ and $V_{2 c}$, and has a greater value than a thick and rough surface. In the latter case, $V_{1 C}$ or $V_{2 C}$ may not appear entirely, or even if they did, the value would be very small. Also the low temperature affords a better opportunity for both $V_{1 C}$ and $V_{2 C}$ with a greater value.

(e) Judging from the facts stated above, it will not be difficult to see for thin and smooth planks that: at the speed below $V_{1 C}$, there is a laminar flow, the range between $V_{1 C}$ and $V_{2 C}$ is an unstable zone, and at the speed above $V_{2 C}$, there is a turbulent flow, producing the frictional resistance of the same nature as those of longer planks, i.e., $R_{f} \infty V^{1.90}$.

With 1-, 2- and 3-foot thin and smooth planks at normal temperature, the turbulent flow will be produced only at higher speeds than about 800, 400 and $300 \mathrm{ft}$. per min. respectively, with a 4-foot plank rising more than $380 \mathrm{ft}$. per min., and with 5-foot and longer planks practically at any speeds. Therefore, if the frictional resistance of thin and smooth planks were considered at the speeds above $V_{2 \sigma}$ for 4-foot and shorter planks, and at any speeds except very low speeds for 5 -foot and longer planks, a proper conclusion will be obtained.

Further, the edge effect $x$ of 1-, 2-, 3- and 4-foot planks is constant in all zones except the vicinity of $V_{1 C}$ and $V_{2 C}$, regardless of the length and surface, so long as they are sufficiently thin. The fact that the value of the edge effect $x$ is the same whether the flow is laminar, or unstable, or turbulent, should not be overlooked in studying the nature of the edge-effect. 


\section{Appendix II.}

The Scale Effect of Thick Planks.

The total resistance of the thick plank exceeding the limiting thickness may be regarded as consisting of a frictional and residuary resistance. In right hand sketch, $A^{\prime} A$ and $B^{\prime} B E N$ are $R$ to base $d$ curves at a given speed, of thick and thin planks respectively. $\overline{O D}$ is the minimum draught, and $\overline{O D^{\prime}}$ the next deeper draught in the experiment. Curve $B^{\prime} B E N$ for the thin plank being a straight line, at the draught $D$

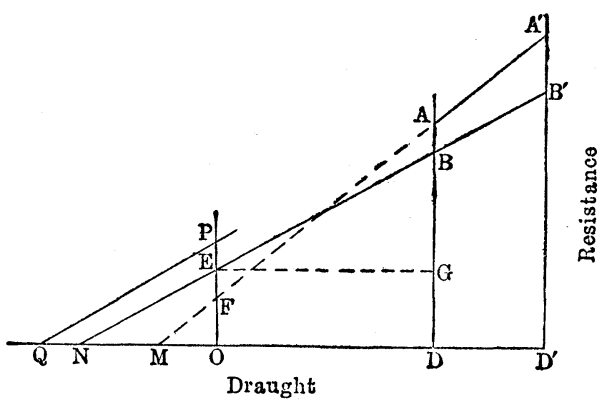

Total $R_{f}=$ Net $R_{f}+R_{f}$ due to edge effect,

$$
\overline{B D}=\overline{B G}+\overline{O E} \text {. }
$$

The nature of the curve $A^{\prime} A$ for the thick plank at the draughts less than $D$ is not yet known. $\overline{A B}$ is the difference of the measured resistances of the thick and thin planks at the draught $D$. To find the residuary resistance and the total $R_{f}$, the sum of which is the total measured resistance $(\overline{D A})$ of the thick plank, the net $R_{f},(\overline{B G})$ having no material change in the surface area, it may be considered common to the thick and thin planks, therefore if $R_{f}$ due to the edge effect was found, it would suffice the total $R_{f}$. Let $\overline{O P}$ be $R_{f}$ due to the edge effect of the thick plank, $\overline{P Q}$ be parallel to $\overline{E N}$, and $\overline{O Q}$ be the edge effect corresponding to $\overline{O N}$ or $x$ of the thin plank. $P$ may be above, at, or below $E$, and $Q$ at left, at, or at right hand side of $N$, then $R_{f}$ to base $d$ curve of the thick plank is represented by $A^{\prime} A P Q$, and $\overline{E^{\prime} P}$ will be $R_{f}$ due to an extra edge effect, peculiar to the thick plank over the thin plank.

$$
\text { Residuary resistance }=\overline{A B}-\overline{E P} \text {. }
$$

Let $\overline{O P}=(1+C) \overline{O E}$, and $\overline{O Q}=(1+C) \overline{O N}$ or $(1+C) x$ where $C \geqq 0$ according to whether $P$ lies above, at, or below $E$.

Then, $R_{f}$ due to the extra edge effect $\overline{E P}=C \times \overline{O E}=C \times 2 K L x V^{1.90}$ at a constant temperature. Assuming $C$ is a constant for similar models at a similar draught, and consider a plank (1) and a longer similar plank (2) of $\lambda_{1}$ times linear dimension, using suffixes 1 and 2 for these planks, at corresponding speeds,

$\left(\text { Extra } R_{f}\right)_{2}=C \times 2 K L_{2} x_{2} V_{2}^{1.90}=C K^{\prime} x_{2}, \quad$ where $2 K L_{2} V_{2}^{1.90}=K^{\prime}$.

$\left(\text { Extra } R_{f}\right)_{1}=C \times 2 K L_{2} x_{1} V_{2}^{1.90} \lambda_{1}^{-1.95}=C K^{\prime} x_{1} \lambda_{1}{ }^{-1.95}$.

Therefore, (Residuary $R)_{1}=\overline{A B}_{1}-C K^{\prime} x_{1} \lambda_{1}^{-1.95}$, 
(Residuary $R)_{2}$ deduced from $(1)=\overline{A B}_{1} \lambda_{1}{ }^{3}-C K^{\prime} x_{1} \lambda_{1}{ }^{1.05}$

Similarly, (Residuary $R)_{2}$ deduced from plank (a) similar to

$$
\text { but shorter than (1) }=\overline{A B}_{a} \lambda_{a}{ }^{3}-C K^{\prime} x_{a} \lambda_{a}{ }^{1.05} \text {. }
$$

Then,

$$
\overline{A B}_{a} \lambda_{a}{ }^{3}-\overline{A B}_{1} \lambda_{1}^{3}=C K^{\prime}\left(x_{a} \lambda_{a}{ }^{1.05}-x_{1} \lambda_{1}{ }^{1.05}\right),
$$

and, since (a) is shorter than (1), $\left(x_{a} \lambda_{a}{ }^{1.05}-x_{1} \lambda_{1}{ }^{1.05}\right)>0$.

Therefore, $C \gtreqless 0 \quad$ according as $\overline{A B}_{a} \lambda_{a}{ }^{3}-\overline{A B}_{1} \lambda_{1}{ }^{3} \gtreqless 0$.

Now, if the similar 4-, 5-, 8- and 14-foot planks in $\S 25$ be represented by $\left(a_{1}\right),\left(a_{2}\right)$, $\left(a_{3}\right)$ and (1) respectively, and the 20-foot plank by (2), then the values of $x_{a} \lambda_{a}{ }^{1.05}-$ $x_{1} \lambda_{1}{ }^{1.05}$ for the four planks 4 to 14 feet in length will be $3.70,2.58,0.95$ and 0 respectively, taking $x$ in inch, and the smaller $(a)$ is than (1), the greater will be its value. Therefore, $C$ will be positive and constant or approximately constant if $\overline{A B}_{a} \lambda_{a}{ }^{3}-\overline{A B}_{1} \lambda_{1}{ }^{3}$ is positive and the smaller $(a)$ is, the greater is its value. A few examples of $\overline{A B} \lambda^{3}$ worked out, in which $\overline{A B}$ of each plank is deduced to the 20 -foot plank, are shown in $\overline{A B} \lambda^{3}$ (assumed residuary resistance) to base $V$ curves at two constant values of $d / L$ in Figs. 83, 84, Plate XI. From which it will be seen that the difference between these curves and the 14-foot plank curve is then $\overline{A B_{a}} \lambda_{a}{ }^{3}-\overline{A B_{1}} \lambda_{1}{ }^{3}$, and their values, excluding the 4foot plank at present as a special case, are all positive, and the shorter $(a)$ is than (1), the greater is its value at any speed,

therefore, $C>0$,

that is, $P$ lies above $E$, and $Q$ on the left hand side of $N$.

In addition, $\overline{A B}_{a} \lambda_{a}{ }^{3}-\overline{A B}_{1} \lambda_{1}{ }^{3}$ is approximately proportional to $V^{1.90}$, which suggests that $C$ is practically independent of $V$. Further, with a change of draught, their greater values at the other sets of deeper draughts indicate a tendency that $C$ will have a greater value at a deeper draught.

$\overline{A B}_{a} \lambda_{a}{ }^{3}$ for the 4-foot plank aforementioned lies between those of the 5 - and 8-foot planks, which may be explained, if $x$ for the 4 -foot thick plank was considered to be less than that of the thin plank due to some reasons.

In short, although $\overline{A B}$ is the difference of measured resistance of the thick and thin planks and a small quantity, the nature such as stated above was ascertained; that is to say, when the thickness exceeds 1/200 length, there is a greater edge effect or scale effect $(1+C) x$ for the edge effect $x$ in thin planks with $C$ independent of the speed, and greater at a deeper draught, and $C=0$ in thin planks. $C$ may be called the coefficient of the scale effect for thick planks, and the frictional resistance of the thick plank of a rectangular shape will have a form

$$
R_{f}=K_{1} S\{1+(1+C) L x /(6 S)\} V_{K}^{1.90} \rho \nu^{0.165},
$$


or more generally for the thick plank having a cut-up at the aft end of the lower edge, it will be

$$
R_{f}=K_{1} S\left\{1+\left(L^{\prime}+C L\right) x /(S)\right\} V_{K^{1.90}} \nu^{0.165} .
$$

The above was originally founded on an assumption that $C$ is a constant for similar planks at a similar draught, but the result of investigations has shown nothing contrary to that assumption. With ship-models which was described in $\S 26$ to $\S 28$, also similar results were obtained with the same assumption.

Further, if $A^{\prime} A$ were extended as a straight line $A^{\prime} A F M$ as it would usually appear, $\overline{O F}$ will be approximately equal to $\overline{O E}$ at lower speeds, and much smaller at higher speeds, which clearly shows the impossibility of consistency with the above result.

\section{Appendix III.}

\section{Peculiarities of the Edge Effect Observed in the Experiments.}

(1) With a thin smooth surface having the ends and edge knife-edged, there is an existence of the edge effect, its value is independent of the speed and temperature, it decreases with the increase of the length, and at the length exceeding 26 feet it is zero or very small.

(2) With thin smooth planks, the smoother the surface, the greater is the edge effect.

(3) A cut-up at the fore end of the lower edge of a plank does not affect the edge effect, but a cut-up at the after end causes a decrease of the edge effect in proportion to the length of cut-up.

(4) With short thin and smooth planks, the edge effect is constant in all three zones of laminar, unstable and turbulent flows.

(5) The edge effect is the true edge effect only when $n$ is independent of the draught, and $R$ to base $d$ curves are straight lines, but the nature of the edge effect calls for further investigations, when $n$ changes with the draught.

(6) An increase in the thickness of planks causes $n$ to change with the draught and the investigation described in Appendix II shows that the edge effect is increased over the edge effect $x$ of thin planks by $C x$.

(7) A fine wire coiled around the fore end of planks, destroys the edge effect.

(8) In 4- and 5-foot plank experiments, a rounding-off of the edge of the plank causes a decrease of the edge effect. 
(9) A rounding-off of the ends and edge of planks causes $n$ to change with the draught, therefore, though the existence of the edge effect is observable, its nature is yet ambiguous.

(10) By the merit of experiments of a submerged plank and L-shaped planks the hitherto so-called edge effect was proved to be a true edge effect, and not a water line effect.

(11) With a rough surface, there. is also an existence of the edge effect.

Referring and relying on the shove particulars, it may be conceived that, though the true nature of the edge effect is not yet clearly known, its origin may be attributed to a disturbance of the flow near the edge due to the discontinuity of the surface on botî sides of the plank at the edge, and that the controlling source of this disturbance having its existence at the fore end of the plank, the longer the plank, the less will be the disturbance, which, ultimately with a long plank over about 26 feet in length, may be quite negligible, or may not occur at all.

\section{Appendix IV.}

\section{Wall and Bottom Effect of an Experimental Tank on the Resistance of Ship-models.}

In the author's collected data of experiments with the same models carried out in two Tanks, and in which the wall and bottom effect was recognized, there are two cases. In one, up to a certain speed, the results of the two Tanks agree perfectly, but above that speed, the recorded resistance of the small Tank is higher than that of the large Tank; in this instance, it was considered that the accuracy of the two Tanks was equal, but the wall or bottom effect was produced in the small Tank above that speed. In another, the results of the two Tanks disagree throughout the experiments; in this instance, the starting point of the diverging curves was taken to be the highest speed, not affected with the wall or bottom effect.

Data obtained under the above conditions are shown in Table XI.

Let $B, D$ and $A$, be the breadth, depth and sectional area of the tank water, and $b, d, a$ and $l$ be the breadth, depth, sectional area and length of the model. Referring to this Table, the limiting value of the speed-length ratio $v / \sqrt{l}$ being constant regardless of the great variation of $d, D / d$ or $A / a$ is not important elements directly connected with the wall or bottom effect; on the contrary, $D / l$ and $B / b$ bear an important relation, i.e., the relation may be approximately represented by : $v / \sqrt{l}=$ 
$1.8 D / l$, when $B / b$ value is in the range of 10 to 17 , and $v / \sqrt{l}=0.13 B / b$, when: $D / l$ value is in the range of 0.6 to 1.2 , and the limiting value of the speed-length ratio with the wall or bottom effect when $(B D) /(b l)$ value is in the range of 6 to 21 , by

$$
v / \sqrt{l}=0.48 \sqrt{(B D) /(b l)} .
$$

$v / \sqrt{\imath}$ to base $(B D) /(b l)$ curve is shown in Fig. 88, Plate XII.

Therefore, when similar models are to be tested in two Tanks, if the bl-ratio of the two models is made to the $B D$-ratio of the two Tanks, a wall or bottom effect at the same $v / \sqrt{l}$ would be obtained. Hence a model for the navy small Tank, and a model having the size of 3.1 times of the small-tank model for the Mitsubishi Tank would commence to suffer the wall or bottom effect at the same $v / \sqrt{ } l$.

Further, if over-resistance 1 per cent. be allowed, with six models experimented in the small Tank, $v / \sqrt{l}$ may be increased by 15 to 20 per cent.. Accordingly, in the small Tank, in which the breadth of water is 6 feet and the depth of water is 4 feet, the maximum $v / \sqrt{l}$ not affected by the wall or bottom effect will be roughly:

4-foot model

5-foot model

6-foot model
Battleships, merchant ships

$(l / b=7)$

1.6-1.8

1.2-1.4

1.0-1.2
Destroyers, very fine ships

$(l / b=11)$

$2.0-2.2$

$1.6-1.8$

$1.3-1.5$ 
TABLE I.

Values of $a$ and $b$ in $R_{f}=\rho S V^{2}\left\{a+b\left(\frac{V L}{\nu}\right)^{M}\right\}$.

\begin{tabular}{|c|c|c|c|c|c|c|c|c|}
\hline \multirow{2}{*}{$\begin{array}{c}\text { Temperature } \\
{ }^{\circ} \mathrm{F} \text {. }\end{array}$} & \multicolumn{2}{|c|}{ (1) $M=-1 / 2$} & \multicolumn{2}{|c|}{ (2) $M=-1 / 3$} & \multicolumn{2}{|c|}{ (3) $M=-0.10$} & \multicolumn{2}{|c|}{$\left(3^{\prime}\right) M=-0.10$} \\
\hline & a & b & a & $\mathrm{b}$ & a & b & & $\frac{b L^{-0.10} \nu^{0.10}}{L^{-0.165} \nu^{0.165}}$ \\
\hline 39.9 & 0.00161 & 0.300 & 0.00137 & 0.055 & 0 & 0.0078 & & 0.0176 \\
\hline 42.9 & " & 0.200 & " & 0.049 & טو & 0.0074 & & 0.0168 \\
\hline 50.9 & כو & 0.182 & , & 0.047 & " & 0.0074 & & $0: 0169$ \\
\hline 78.9 & " & 0.071 & , & 0.042 & 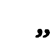 & 0.0073 & & 0.0171 \\
\hline 99.7 & " & 0.049 & 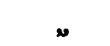 & 0.035 & ״ & 0.0072 & & 0.0173 \\
\hline 103.5 & " & 0.046 & $"$ & 0.034 & 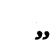 & 0.0072 & & 0.0173 \\
\hline 120.2 & , & 0.027 & 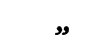 & 0.031 & و & 0.0073 & & 0.0176 \\
\hline & & & & & & & Mean & 0.0172 \\
\hline
\end{tabular}

TABLE II.

Comparison of Temperature Effects.

\begin{tabular}{|c|c|c|c|c|c|c|}
\hline \multirow{2}{*}{$\begin{array}{c}\text { Temperature } \\
{ }^{\circ} \mathrm{F} \text {. }\end{array}$} & \multicolumn{2}{|c|}{$\begin{array}{l}\text { Unwin's rotating cylinder } \\
\text { ( } N \text { revolutions per sec.) }\end{array}$} & \multicolumn{2}{|c|}{$\begin{array}{l}\text { Shigemitsu's rotating } \\
\text { cylinder at velocities } \\
\text { above the critical } \\
\text { speed }\end{array}$} & \multicolumn{2}{|c|}{$\begin{array}{l}\text { The author's } \\
\text { planks and models }\end{array}$} \\
\hline & $n$ in $N^{n}$ & $\begin{array}{l}\text { Rate of } \\
\text { variation } \\
\text { of } \\
\text { resistance }\end{array}$ & $\boldsymbol{n}$ in $\nabla^{n}$ & $\begin{array}{l}\text { Rate of } \\
\text { variation } \\
\text { of } \\
\text { resistance }\end{array}$ & $n$ in $\nabla^{n}$ & $\begin{array}{l}\text { Rate of } \\
\text { variation } \\
\text { of } \\
\text { resistance }\end{array}$ \\
\hline 41.2 & 1.85 & 100.0 & & & 1.90 & 100.0 \\
\hline 53.0 & , & 94.6 & & & טs & 97.0 \\
\hline 70.4 & " & 91.5 & & & טs & 93.2 \\
\hline 130.5 & و & 82.6 & & & • & 82.8 \\
\hline 77.5 & & & $1.75,1.78,1.79 *$ & $100.0^{*}$ & פ & 100.0 \\
\hline 122.4 & & & $1.75,1.78,1.79 *$ & $91.7^{*}$ & , & 91.3 \\
\hline
\end{tabular}

* derived from the published data. 


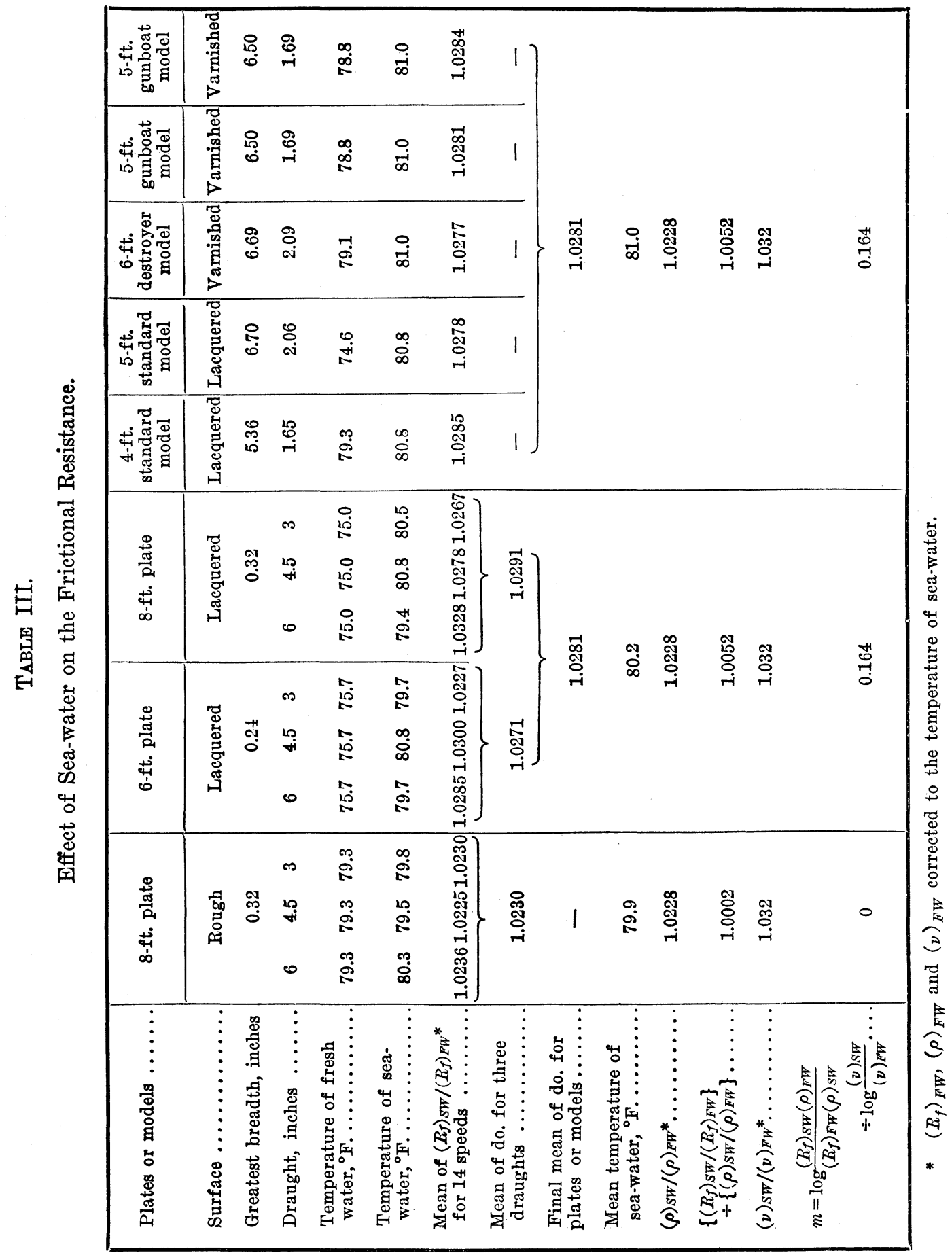


TABLe IV.

Planks Experimented, Excluding Lacquered-surface Planks.

\begin{tabular}{|c|c|c|c|c|c|c|c|c|c|}
\hline Nature of Surface & Material & $\begin{array}{c}\text { Length } \\
\mathrm{ft.}\end{array}$ & $\begin{array}{c}\text { Greatest } \\
\text { thickness } \\
\text { inch } \\
\end{array}$ & $\begin{array}{c}\text { Draught } \\
\text { inches }\end{array}$ & $\begin{array}{l}\text { Mean } \\
\text { temper- } \\
\text { ature } \\
{ }^{\circ} \mathrm{F} \text {. } \\
\end{array}$ & $\begin{array}{c}x \\
\text { inch } \\
\end{array}$ & $\stackrel{n}{\boldsymbol{n}}$ & $\begin{array}{c}k_{2} \\
\text { (mean) }\end{array}$ & $\begin{array}{c}\text { Year of } \\
\text { experi- } \\
\text { ment }\end{array}$ \\
\hline Painted & Brass & 2 & 0.16 & 3,6 & 69.5 & 0.52 & 1.923 & 0.01227 & 1927 \\
\hline פ & " & 4 & 0.16 & $3,6.5$ & 78.1 & 0.46 & 1.896 & 0.01006 & 1927 \\
\hline 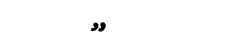 & 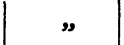 & 5 & 0.20 & $2,3,4.5,6$ & 47.4 & 0.43 & 1.901 & 0.01021 & 1928 \\
\hline " & " & 6 & 0.20 & $3,4,6$ & 78.4 & 0.40 & 1.877 & 0.00986 & 1928 \\
\hline פ & " & 8 & 0.20 & 3,6 & 39.6 & 0.34 & 1.898 & 0.00987 & 1928 \\
\hline$"$ & Wood & 25.774 & 1.75 & $11.08,14.08$ & 54.5 & 0 & 1.908 & 0.01038 & 1927 \\
\hline Paraffin & Wood & 6 & $0.16^{*}-0.42 \dagger$ & 6,10 & 72.7 & 0.40 & 1.900 & 0.01015 & 1929 \\
\hline " & " & 8 & $0.16 *-0.42 t$ & $4,6,8,10$ & 78.2 & 0.34 & 1.903 & 0.01007 & 1929 \\
\hline " & $"$ & 14 & $0-0.67$ & $2,3,4.5,6$ & 79.7 & 0.18 & 1.878 & 0.01010 & 1929 \\
\hline و & פو & 20 & $0-0.67$ & $3,4,5,6$ & 80.5 & 0.05 & 1.900 & 0.01005 & 1929 \\
\hline Brass plate & Brass & 5 & 0.20 & 6 & 51.8 & - & 1.877 & 0.00956 & 1926 \\
\hline פو & و & 8 & 0.20 & 6 & 51.8 & - & 1.881 & 0.00961 & 19.26 \\
\hline
\end{tabular}

* Thickness at 2 inches above the lower edge.

$\dagger$ Thickness at 10 inches above the lower edge.

TABLE V.

Scale Effect of "Mitsubishi" Similar Paraffin Models of a Cargo Ship Experimented in the Mitsubishi Tank.

$d / L=0.0556, \quad($ Breadth $) / L=0.125, \Delta /\left(\frac{1}{100} L\right)^{3}=147,{ }^{*}$ Prismatic coefficient $=0.730$.

\begin{tabular}{|c|c|c|c|c|c|c|c|c|c|c|c|}
\hline Model number & 329 & 330 & 331 & 332 & 333 & 324 & 335 & 336 & 337 & 338 & 339 \\
\hline Length $\left(L=L^{\prime}\right)$, ft. & 5 & 6.25 & 7.5 & 8.75 & 10 & 11.25 & 12.5 & 13.71 & 15.00 & 16.36 & 17.46 \\
\hline Displacement, lb. ... & 40.1 & 78.3 & 135.3 & 214.9 & 320.8 & 456.7 & 626.5 & 827.3 & 1083 & 1406 & 1706 \\
\hline Surface area $(\mathrm{S}), \mathrm{ft}^{2}$ & 4.69 & 7.33 & 10.56 & 14.37 & 18.77 & 23.76 & 29.33 & 35.30 & 42.23 & 50.26 & 57.18 \\
\hline Temperature, ${ }^{\circ} \mathrm{F}$. .. & 64.0 & 62.7 & 61.0 & 60.3 & 60.0 & 60.5 & 68.8 & 61.0 & 63.0 & 62.7 & 58.3 \\
\hline Dimension ratio $(\lambda)$ & 3.49 & 2.79 & 2.33 & 2.00 & 1.75 & 1.55 & 1.40 & 1.27 & 1.16 & 1.07 & 1.00 \\
\hline$\left(\lambda^{3} r-R\right) /\left(S V_{K}^{1.90}\right)$ & 0.00587 & 0.00401 & 0.00352 & 0.00268 & 0.00178 & 0.0009 & $0.0 \Omega 091$ & 0.00041 & 0.00048 & 0.000035 & 0 \\
\hline Do., faired by a curve & 0.00587 & 0.00440 & 0.00325 & 0.00225 & 0.00175 & 0.00120 & 0.00085 & 0.00055 & 0.00032 & 0.000035 & 0 \\
\hline$C \ldots \ldots \ldots \ldots \ldots$ & $\underbrace{3.14}$ & 3.32 & 3.34 & 2.99 & 3.23 & 3.03 & 3.18 & 3.02 & 3.25 & 3.10 & - \\
\hline$C_{m}($ mean value of $C)$ & & & & & & 3.16 & & & & & \\
\hline$x$, in. $\ldots \ldots \ldots \ldots$ & 0.43 & 0.39 & 0.35 & 0.32 & 0.28 & 0.245 & 0.21 & 0.18 & 0.15 & 0.12 & 0.09 \\
\hline$L^{\prime} x /(6 S) \quad \ldots \ldots$ & 0.076 & 0.055 & 0.042 & 0.032 & 0.025 & 0.019 & 0.015 & 0.012 & 0.009 & 0.007 & 0.005 \\
\hline$C_{m} L x /(6 S) \quad \ldots$ & 0.240 & 0.174 & 0.132 & 0.102 & $0.07 \mathrm{~s}$ & 0.060 & 0.047 & 0.037 & 0.029 & 0.021 & 0.015 \\
\hline $1+\left(L^{\prime}+C_{m} L\right) x /(6 S)$ & 1.316 & 1.229 & 1.174 & 1.134 & 1.103 & 1.079 & 1.062 & 1.049 & 1.038 & 1.028 & 1.020 \\
\hline
\end{tabular}

* $\Delta=$ displacement in tons in sea-water. 
Table VI.

Scale Effect of Teishinsho* Similar Varnished Wood-models ${ }^{\dagger}$ of a Cargo Ship Experimented in the Teishinsho Tank.

\begin{tabular}{|c|c|c|c|c|c|c|c|c|c|}
\hline Conditions & \multicolumn{3}{|c|}{ Deep draught } & \multicolumn{3}{|c|}{ Medium draught } & \multicolumn{3}{|c|}{ Light draught } \\
\hline $\begin{array}{l}\quad d / L \\
\text { Prismatic coefficient } \\
\Delta /\left(\frac{1}{100} L\right)^{3} \text {, tons } \times \mathrm{ft}^{-3} \ddagger^{-}\end{array}$ & \multicolumn{3}{|c|}{$\begin{array}{c}0.0663 \\
0.724 \\
187.1\end{array}$} & \multicolumn{3}{|c|}{$\begin{array}{r}0.0471 \\
0.706 \\
128.3\end{array}$} & \multicolumn{3}{|c|}{$\begin{array}{l}0.0324 \\
0.666 \\
82.3\end{array}$} \\
\hline Model number & 5 & 4 & 3 & 5 & 4 & 3 & 5 & 4 & 3 \\
\hline Length $\left(L=L^{\prime}\right)$, ft. $\ldots \ldots \ldots$ & 4.876 & 9.752 & 14.63 & 4.876 & 9.752 & 14.63 & 4.876 & 9.752 & 14.63 \\
\hline Displacement, lb. ........ & 46.8 & 374 & 1266 & 32.2 & 258 & 869 & 20.6 & 165 & 556 \\
\hline Skin area $(S), \mathrm{ft}^{2} \ldots \ldots \ldots$ & 5.11 & 20.44 & 45.99 & 4.08 & 16.33 & 36.72 & 3.41 & 13.64 & 30.70 \\
\hline Temperature, ${ }^{\circ} \mathrm{F} . . . \ldots \ldots$ & 64.2 & 62.6 & 60.6 & 71.0 & 62.2 & 62.0 & 73.2 & 61.7 & 58.8 \\
\hline Dimension ratio $(\lambda) \ldots \ldots$ & 3 & 1.5 & 1 & 3 & 1.5 & 1 & 3 & 1.5 & 1 \\
\hline$\left(\lambda^{3} r-R\right) /\left(S V_{k}^{1.90}\right) \quad \ldots \ldots \ldots$ & 0.00266 & 0.000811 & 0 & 0.00256 & 0.000720 & 0 & 0.00232 & 0.000607 & 0 \\
\hline$C \ldots \ldots \ldots \ldots \ldots \ldots \ldots$ & 2.66 & 3.18 & 一 & 2.02 & 1.66 & - & 1.43 & 1.08 & - \\
\hline$C_{m}($ mean value of $C) \ldots$ & 2.92 & 2.92 & 2.92 & 1.84 & 1.81 & 1.84 & 1.26 & 1.26 & 1.26 \\
\hline 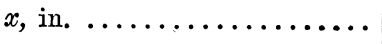 & 0.67 & 0.35 & 0.16 & 0.67 & 0.35 & 0.16 & 0.67 & 0.35 & 0.16 \\
\hline$L^{\prime} x /(6 S) \quad \ldots \ldots \ldots \ldots \ldots$ & 0.106 & 0.028 & 0.008 & 0.133 & 0.035 & 0.011 & 0.160 & 0.042 & 0.013 \\
\hline$C_{m} L x /(6 S) \quad \ldots \ldots \ldots \ldots \ldots$ & 0.311 & 0.081 & 0.025 & 0.246 & 0.064 & 0.019 & 0.201 & 0.052 & 0.016 \\
\hline $1+\left(L^{\prime}+C_{m} \xi\right) x /(6 S) \ldots \ldots$ & 1.417 & 1.109 & 1.033 & 1.379 & 1.099 & 1.030 & 1.361 & 1.094 & 1.029 \\
\hline
\end{tabular}

* Ministry of Communications.

+ Breadth $/ L=0.1385$.

¥ $\Delta=$ displacement in tons in sea-water.

TABLE VIII.

Variation of $(1+x / d)$ with the Length for a Varnished Surface.

\begin{tabular}{|c|c|c|c|c|c|}
\hline \multirow{2}{*}{ Length, ft. } & \multirow{2}{*}{$x$, inch } & \multicolumn{2}{|c|}{ Constant draught } & \multicolumn{2}{|c|}{ Constant $d / L$} \\
\cline { 2 - 5 } & & $d=6$ inches & $d=9.5$ inches & $d / L=0.03$ & $d / L=0.05$ \\
\hline 2 & 0.88 & 1.147 & 1.093 & 2.222 & 1.733 \\
5 & 0.66 & 1.100 & 1.070 & 1.367 & 1.220 \\
8 & 0.46 & 1.077 & 1.048 & 1.160 & 1.096 \\
14 & 0.18 & 1.030 & 1.019 & 1.037 & 1.022 \\
20 & 0.05 & 1.008 & 1.005 & 1.007 & 1.004 \\
26 & 0 & 1.000 & 1.000 & 1.000 & 1.000 \\
\hline
\end{tabular}




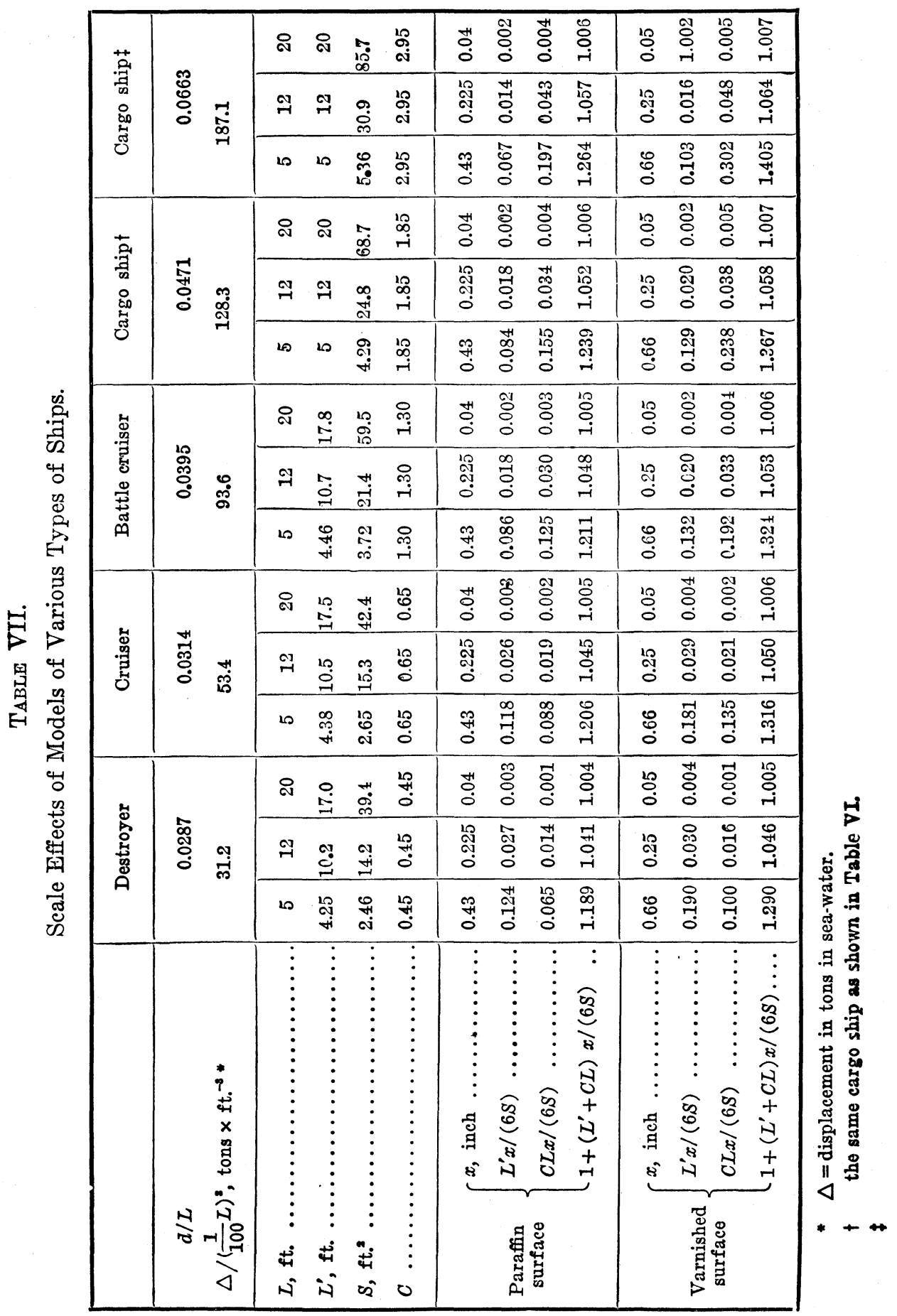


TAble IX.

Measured Resistances in Lb. per Sq. Ft. of Planks by Froude, Kempf and Gebers.

Froude's Planks (thickness 3/16 inch, draught 19 inches, varnished surface and temperature $55^{\circ} \mathrm{F}$.)

\begin{tabular}{|c|c|c|c|c|c|}
\hline \multicolumn{2}{|c|}{ Length, ft. } & 2 & 8 & 20 & 50 \\
\hline \multirow{2}{*}{ At $600 \mathrm{ft}$. per.min. } & $\int$ Froude & 0.41 & 0.325 & 0.278 & 0.250 \\
\hline & The new formula & 0.32 & 0.302 & 0.291 & 0.289 \\
\hline
\end{tabular}

Kempf's Pipes (dia. $35 \mathrm{~cm}$., painted surface and temperature $11^{\circ} \mathrm{C}$.)

\begin{tabular}{|c|c|c|c|c|c|c|c|}
\hline \multicolumn{2}{|c|}{ Length, metres } & 7.30 & 12.16 & 19.13 & 33.70 & 46.40 & 61.75 \\
\hline \multirow{2}{*}{ At $2 \mathrm{~m}$. per sec. } & Kempf & 0.253 & 0.206 & 0.172 & 0.148 & 0.137 & 0.131 \\
\hline & The new formula & 0.133 & 0.133 & 0.133 & 0.133 & 0.133 & 0.133 \\
\hline \multirow{2}{*}{ At $7 \mathrm{~m}$. per sec. } & $\int$ Kempf & 2.84 & 2.21 & 1.86 & 1.60 & 1.50 & 1.43 \\
\hline & The new formula & 1.44 & 1.44 & 1.44 & 1.44 & 1.44 & 1.44 \\
\hline \multirow{3}{*}{ For the 61.75 -metre pipe } & Speed, m. per sec. & 2 & 3 & 4 & 5 & 6 & 7 \\
\hline & Kempf & 0.131 & 0.283 & 0.491 & 0.748 & 1.066 & 1.431 \\
\hline & The new formula & 0.133 & 0.288 & 0.498 & 0.761 & 1.076 & 1.442 \\
\hline
\end{tabular}

Gebers' Planks (thickness $1 / 500 L$, draught $0.05 L$ and varnished surface)

\begin{tabular}{|c|c|c|c|c|c|c|}
\hline \multicolumn{2}{|c|}{ Length, metres } & 1.25 & 2.5 & 5.0 & 7.5 & 10 \\
\hline \multicolumn{2}{|c|}{ Temperature, ${ }^{\circ} \mathrm{C}$. } & 10.2 & 9.9 & 9.7 & 9.7 & 8.3 \\
\hline \multirow{2}{*}{ At $2 \mathrm{~m}$. per sec. } & Gebers & 0.154 & 0.132 & 0.125 & 0.116 & 0.114 \\
\hline & \{ The new formula & 0.170 & 0.143 & 0.133 & 0.131 & 0.132 \\
\hline \multirow{2}{*}{ At $4 \mathrm{~m}$. per sec. } & Gebers & 0.616 & 0.498 & 0.458 & 0.421 & 0.427 \\
\hline & The new formula & 0.635 & 0.535 & 0.497 & 0.491 & 0.494 \\
\hline \multirow{2}{*}{ At $7 \mathrm{~m}$. per sec. } & Gebers & 1.77 & 1.41 & 1.30 & 1.21 & 1.20 \\
\hline & $\{$ The new formula & 1.84 & 1.55 & 1.44 & 1.42 & 1.43 \\
\hline
\end{tabular}

\begin{tabular}{|c|c|c|c|c|c|c|c|c|c|}
\hline Speed, metres per sec. & 2 & 3 & 4 & 5 & 6 & 7 & Mean & $\begin{array}{c}\text { Ratio of } \\
L^{-0.125}\end{array}$ & $\begin{array}{c}\text { Ratio calculated } \\
\text { by } \\
\text { the new formula }\end{array}$ \\
\hline$R_{f} / S$ of $10-\mathrm{m}$. plank $*$ & \multirow{4}{*}{$\begin{array}{l}0.980 \\
0.734\end{array}$} & \multirow{4}{*}{$\begin{array}{l}1.008 \\
0.686\end{array}$} & \multirow{4}{*}{$\begin{array}{l}1.009 \\
0.688\end{array}$} & \multirow{4}{*}{$\begin{array}{l}0.989 \\
0.658\end{array}$} & \multirow{4}{*}{$\begin{array}{l}0.980 \\
0.665\end{array}$} & \multirow{4}{*}{$\begin{array}{l}0.982 \\
0.671\end{array}$} & \multirow{4}{*}{$\begin{array}{l}0.991 \\
0.684\end{array}$} & \multirow{4}{*}{$\begin{array}{l}0.964 \\
0.771\end{array}$} & \multirow{4}{*}{0.999} \\
\hline$R_{f} / S$ of $7.5-\mathrm{m}$. plank & & & & & & & & & \\
\hline $\boldsymbol{R}_{f} / S$ of $10-\mathrm{m}$. plank ${ }^{*}$ & & & & & & & & & \\
\hline$R_{f} / S$ of $1.25-\mathrm{m}$. plank & & & & & & & & & \\
\hline
\end{tabular}

* Resistances of both planks were corrected to the same temperature. 


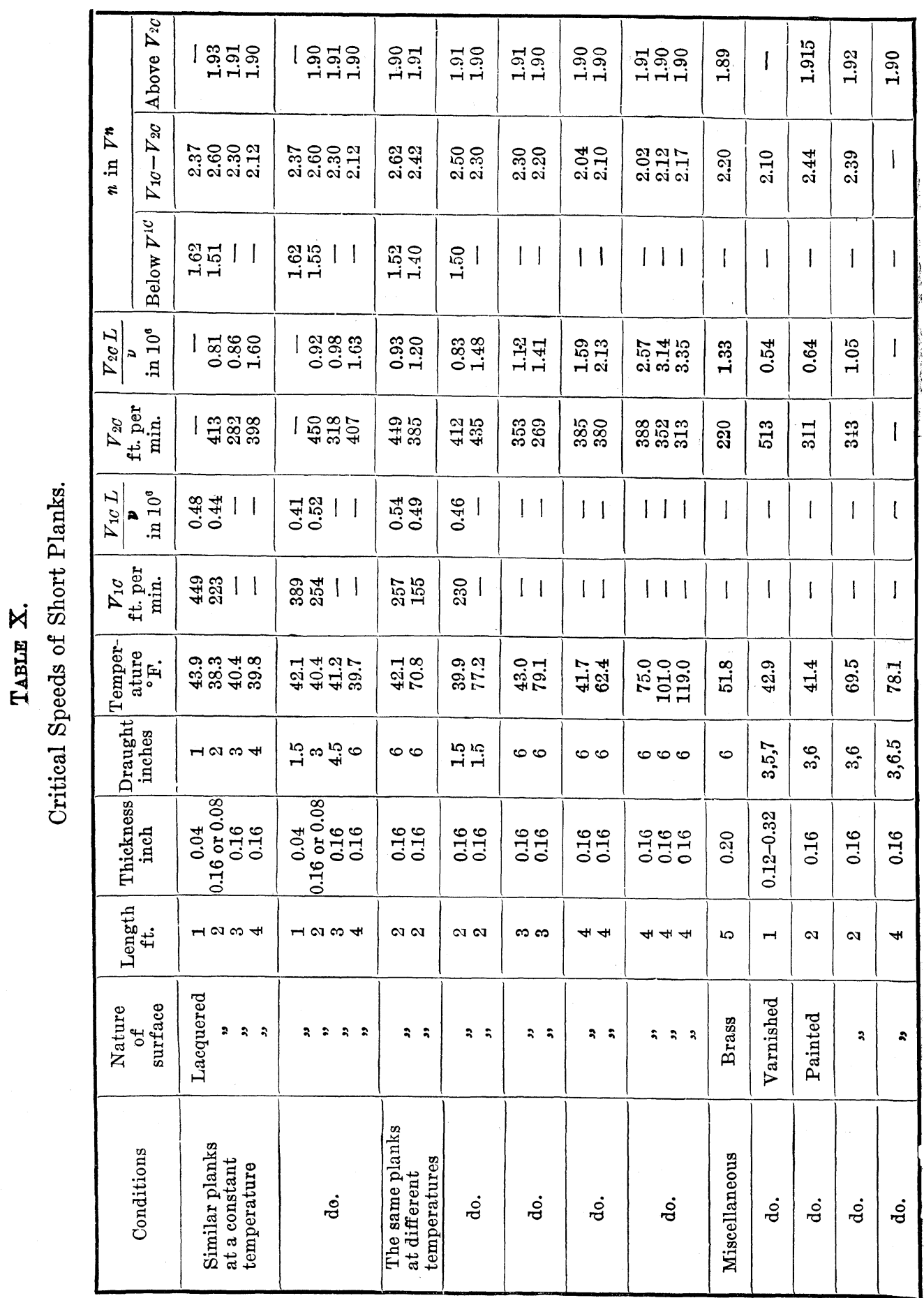




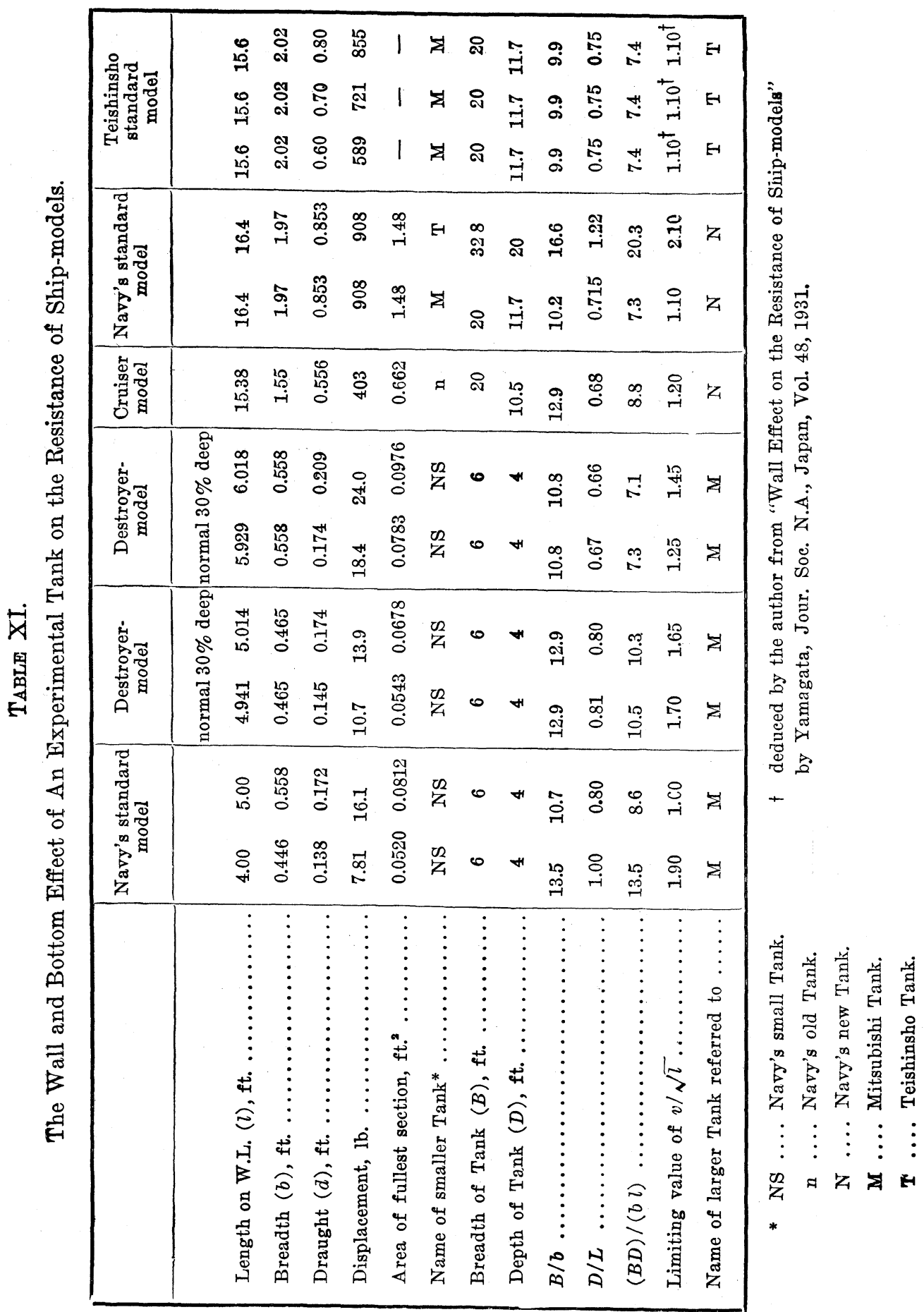


FIG. Ic TOWING APPARATUS FOR SUBMERGED CONDITION. L

FIG. 1b TOWING APPARATUS FOR 8-FT. AND SHORTER PLATES.

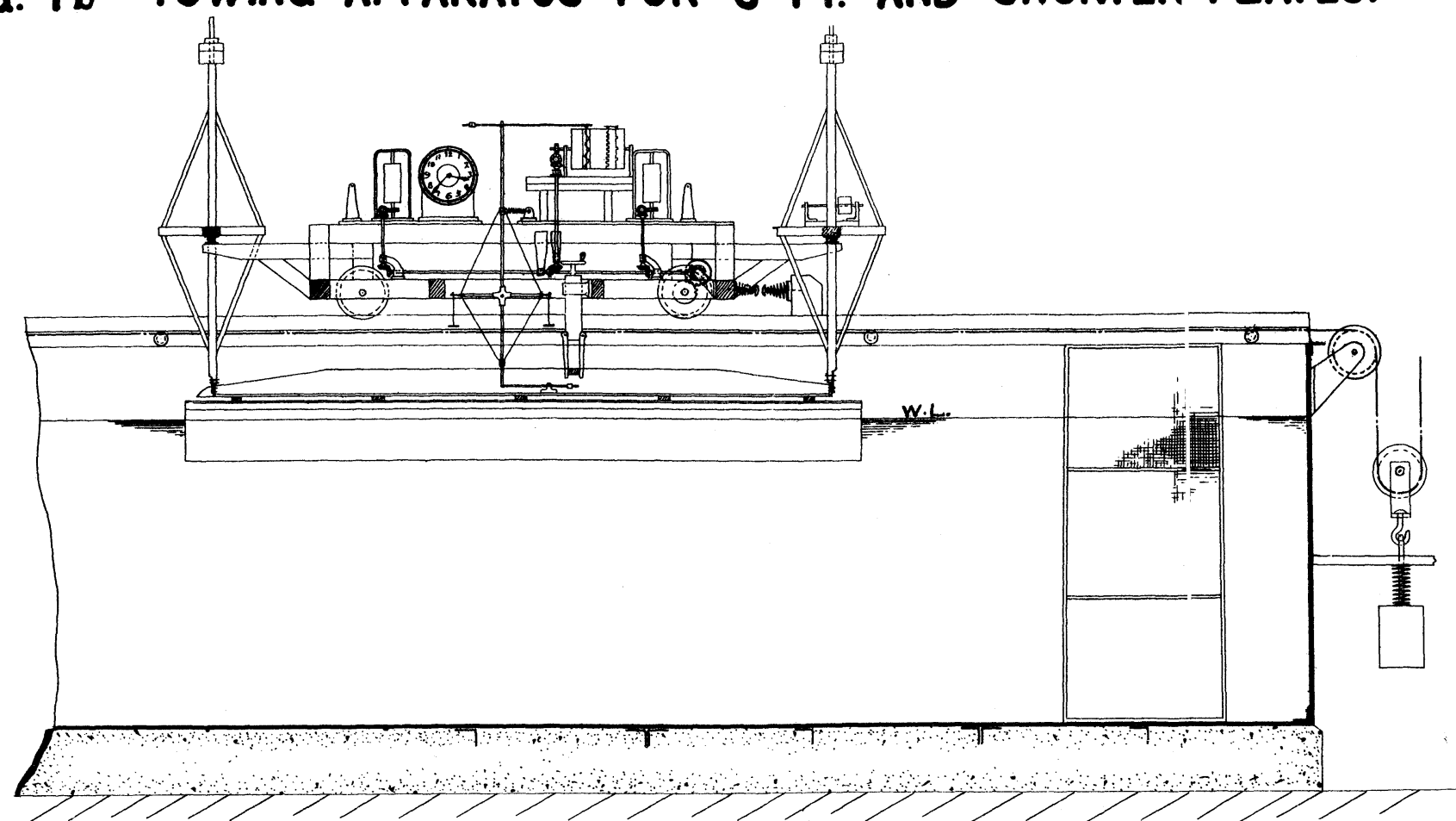

FIG. Ia TOWING APPARATUS FOR 5-FT. SHIP-MODELS.

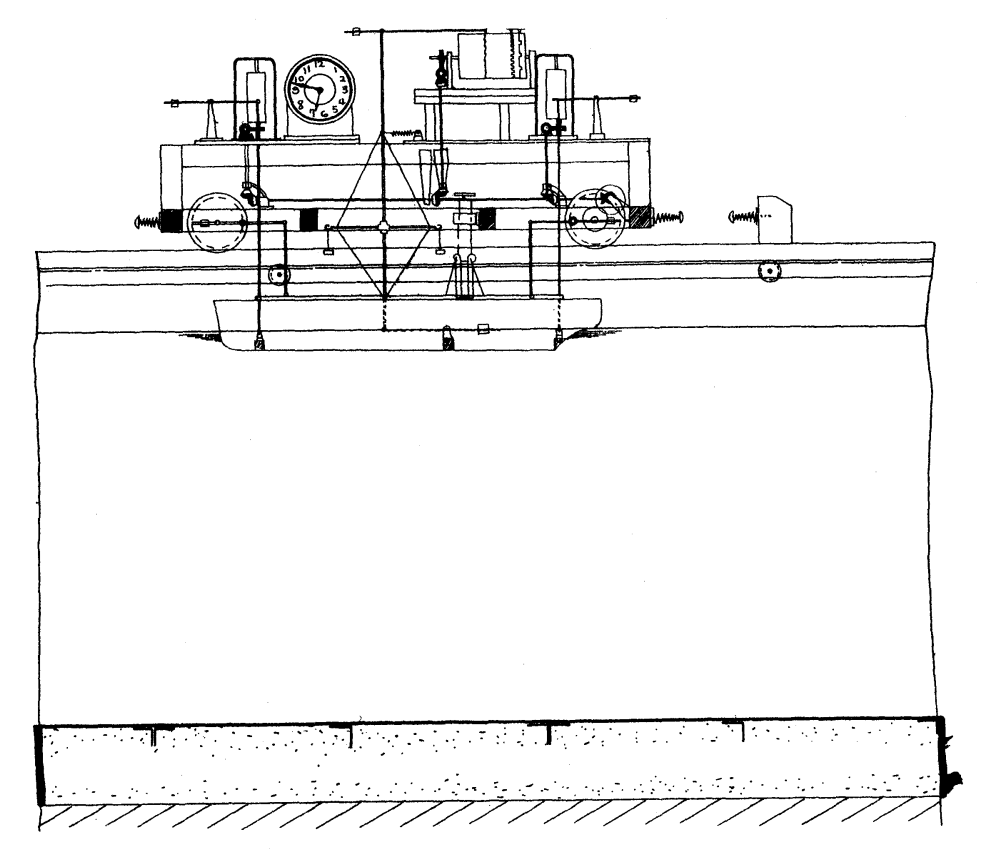

THE NAVY SMALL TANK

PLATE I
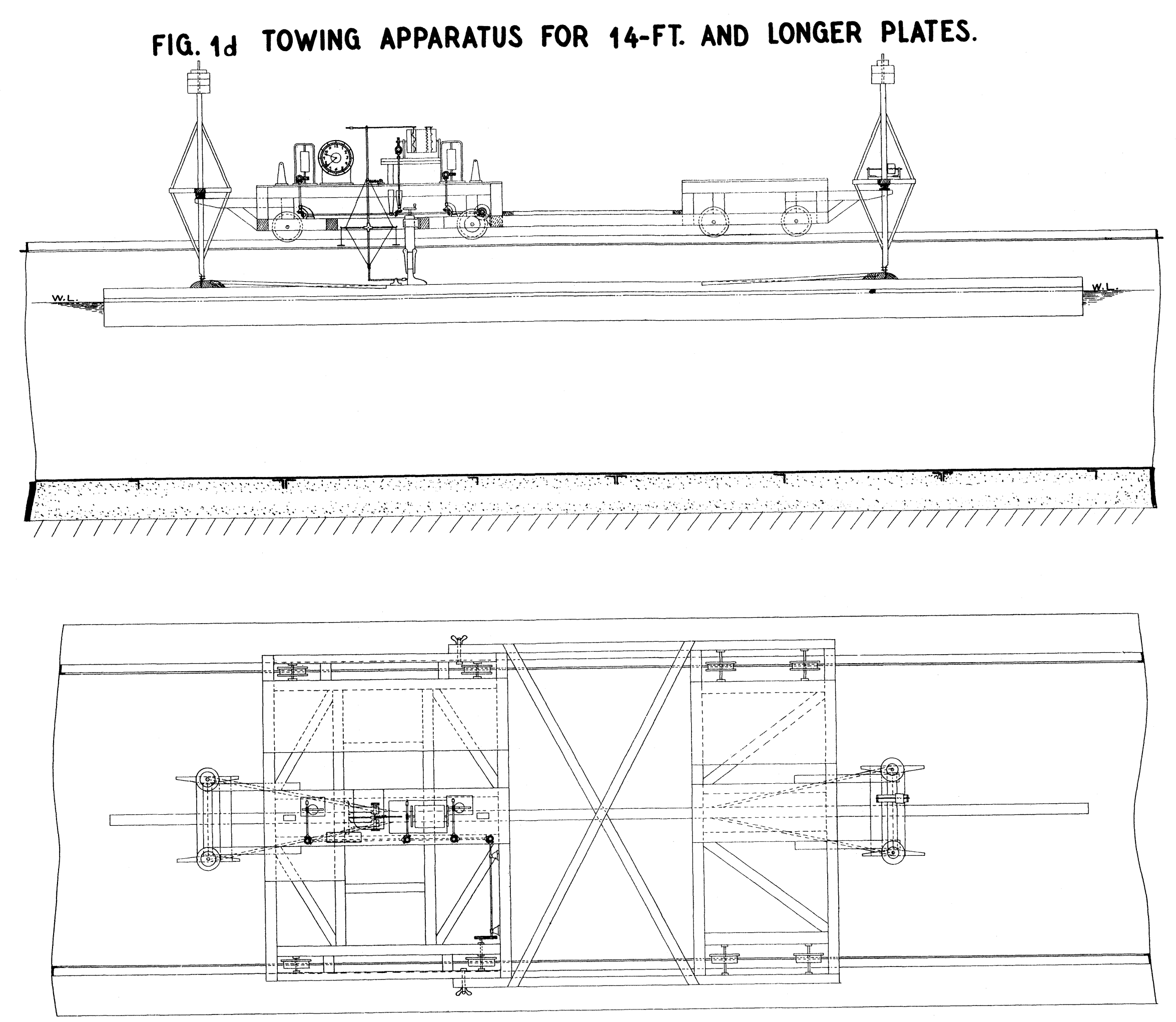

FIG. 1 e

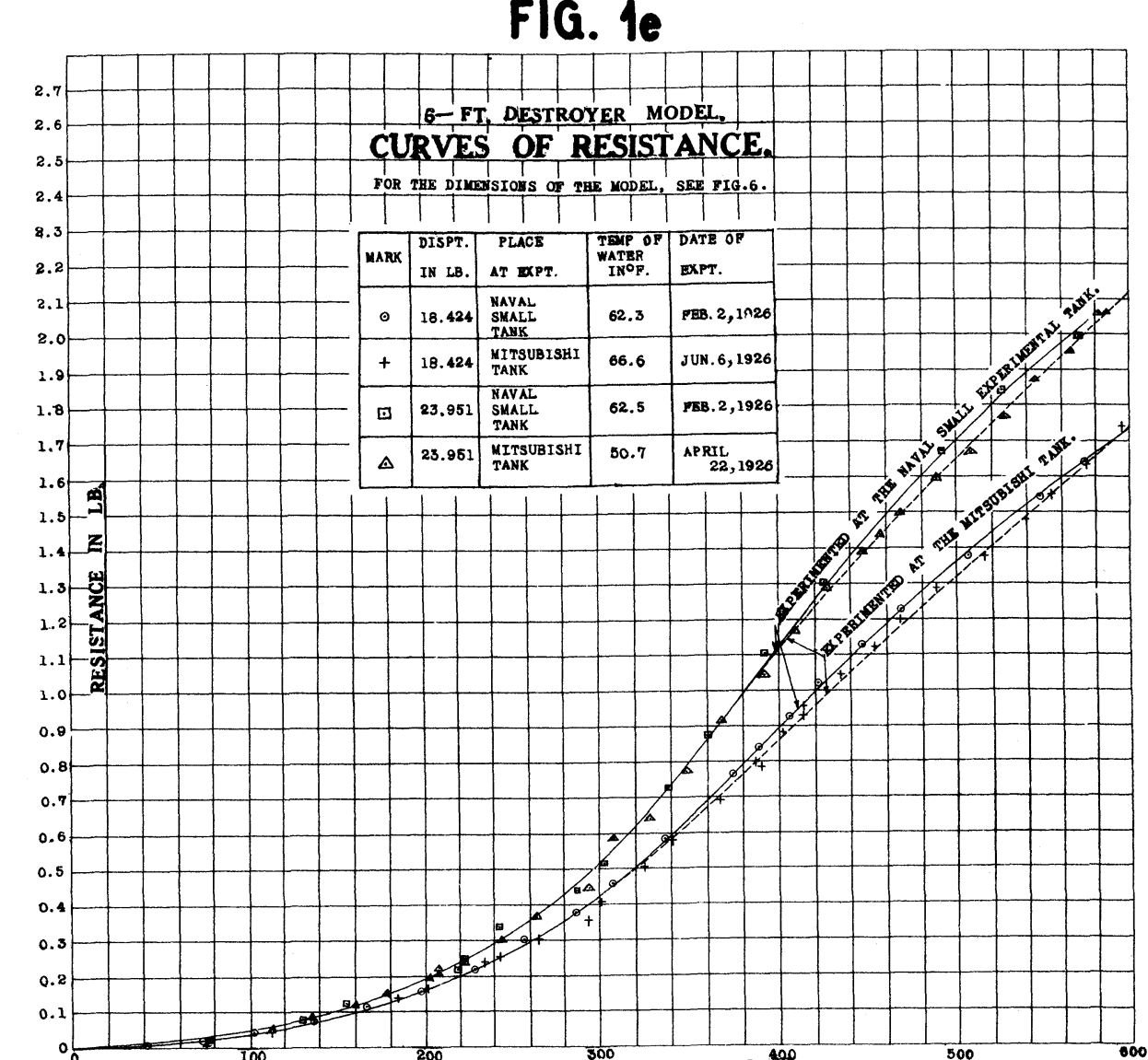

FIG. If

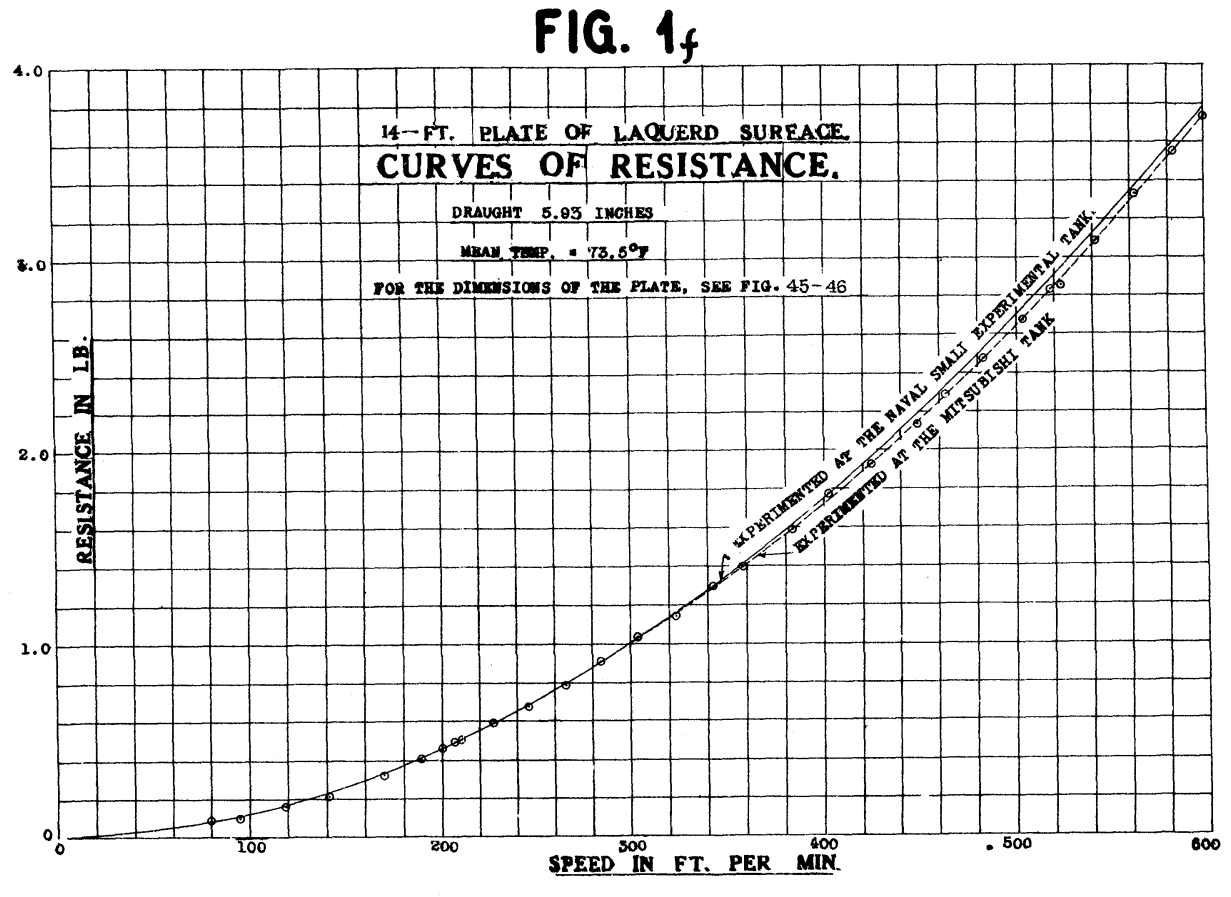


CURVES OF RESISTANCE AGAINST SPEED AT VARYING TEMPERATURES.

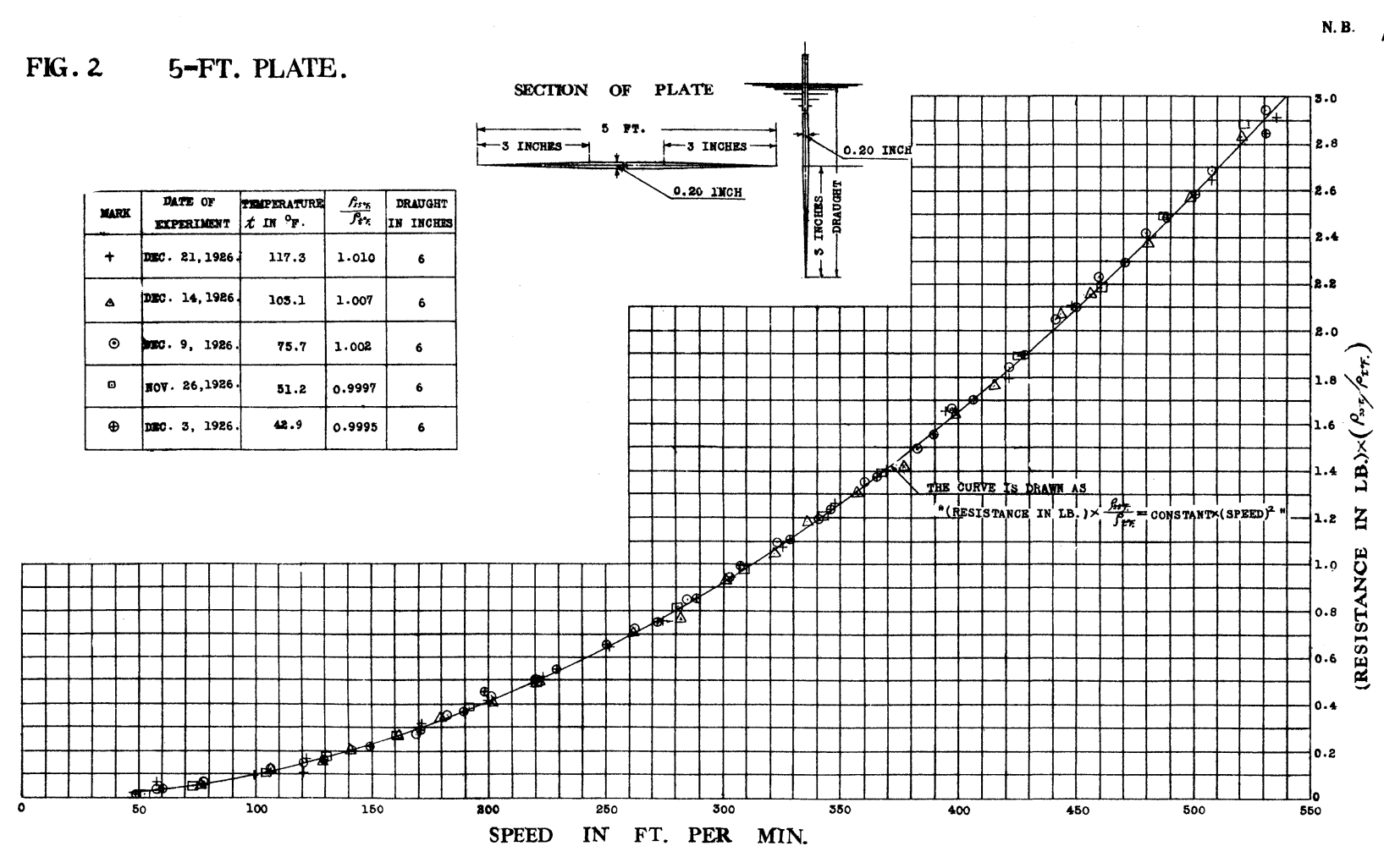

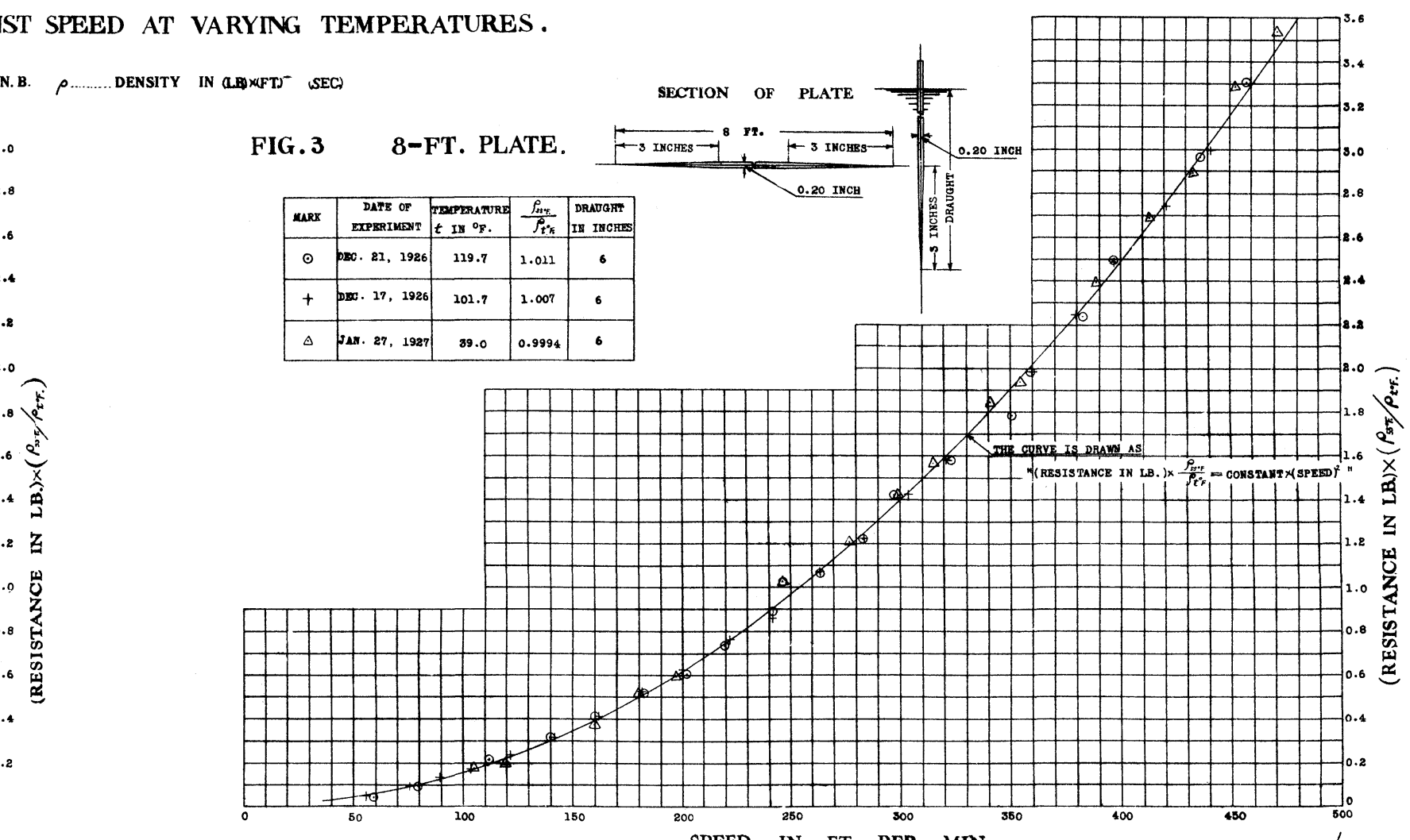

SPEED IN FT. PER MIN.
FIG.5 5-FT. BATTLESHIP-MODEL.

\section{FIG. 4 4-FT. CRUISER-MODEL.}

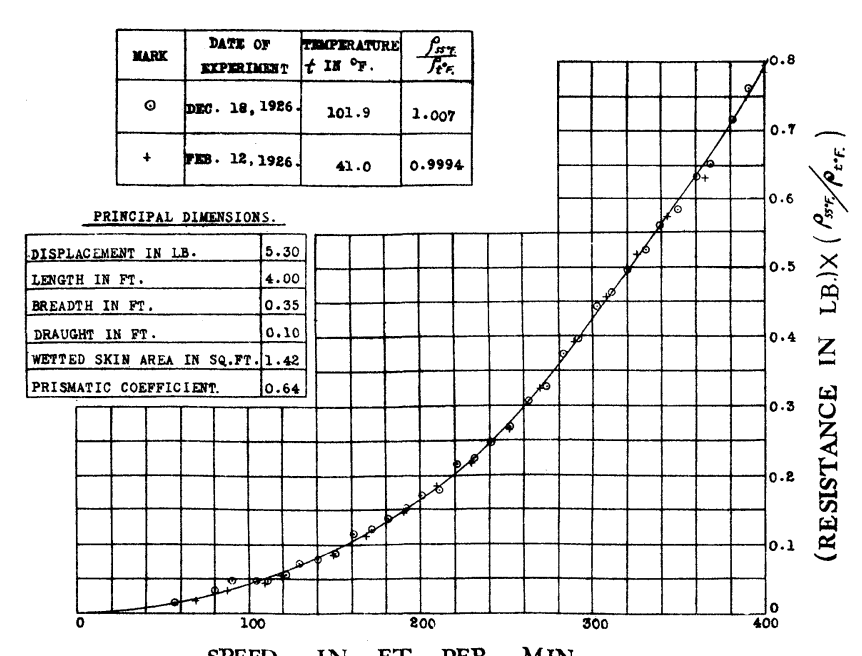

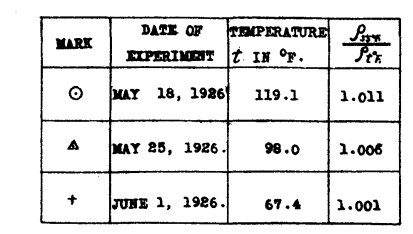

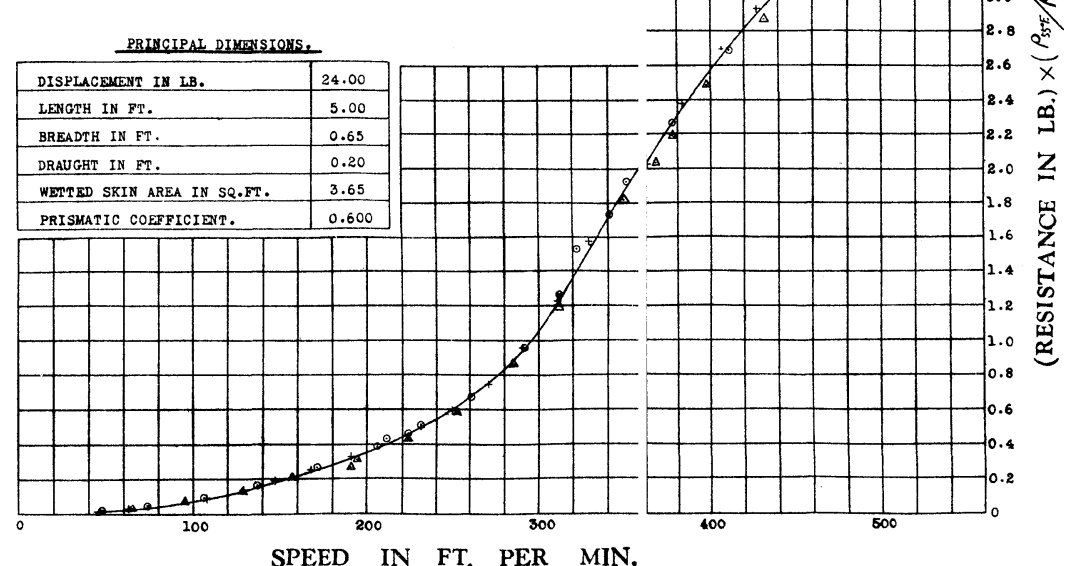

FIG. 6 6-FT. DESTROYER-MODEL.

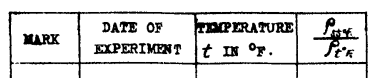

$$
\begin{aligned}
& \text { - } \begin{array}{c|c|c|}
\hline \text { par 20, 1986. } & 188.8 & 1.011 \\
\hline
\end{array} \\
& \begin{array}{l|l|l|l|}
\hline \max 25,1926 & 100.8 & 1.007 \\
\hline
\end{array} \\
& \begin{array}{|c|c|c|c|}
\hline+ & \text { Jusx 1, 1996. } & 67.4 & 1.002 \\
\hline
\end{array}
\end{aligned}
$$

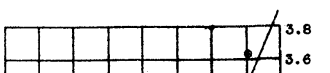

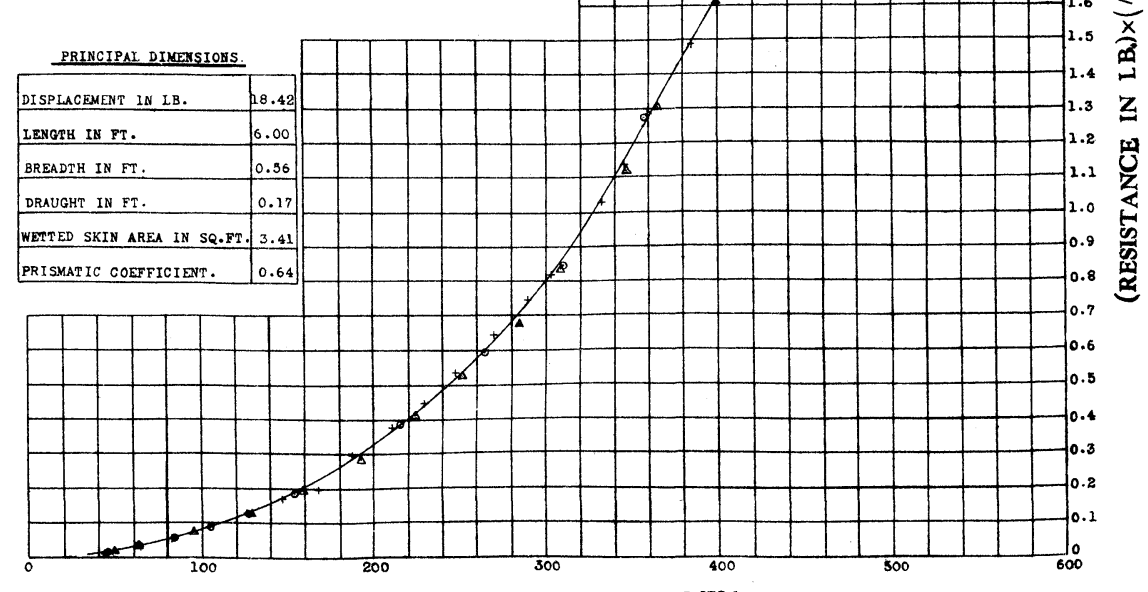

SPEED IN FT. PER MIN 
RESISTANCE OF FLAT PLATES OF LACQUERED SURFACE IN WATER OF VARYiNG TEMPERATURES
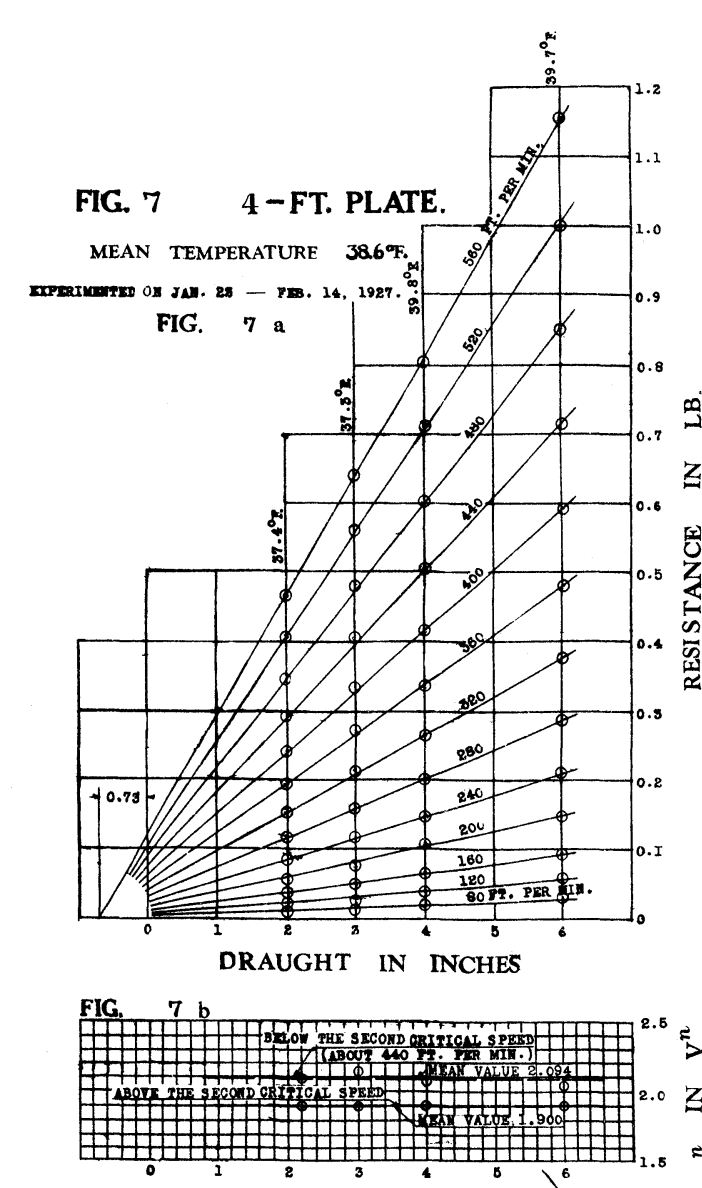

'DRAUGHT IN INCHES

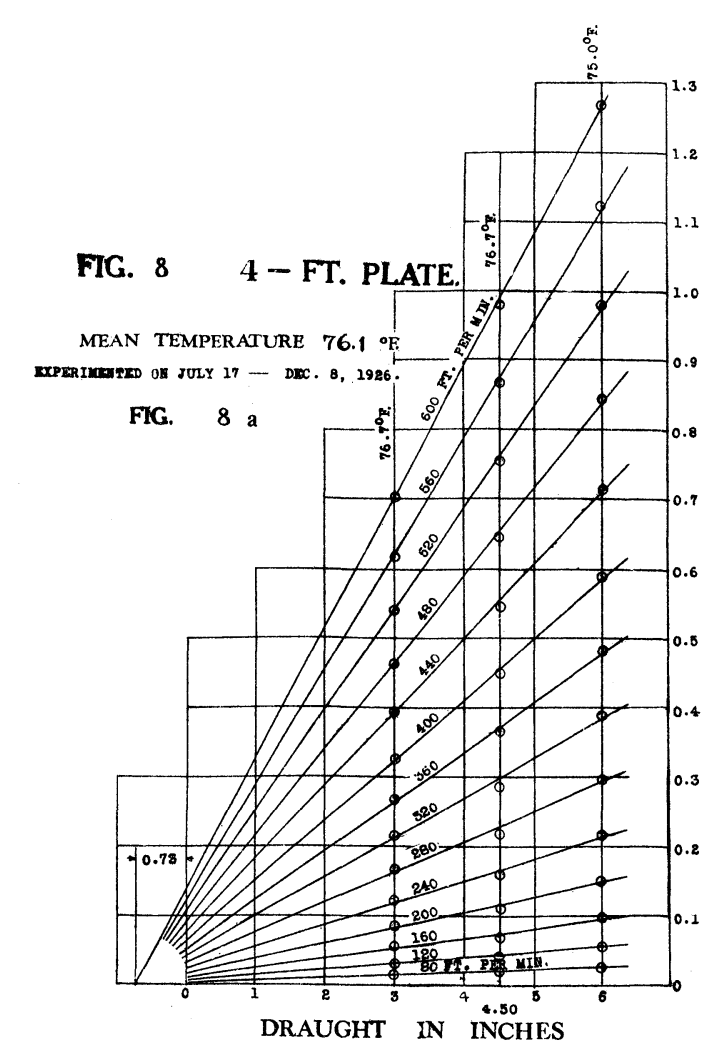

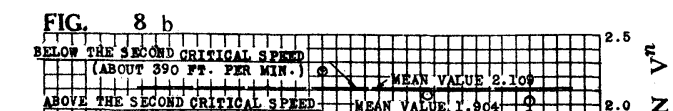

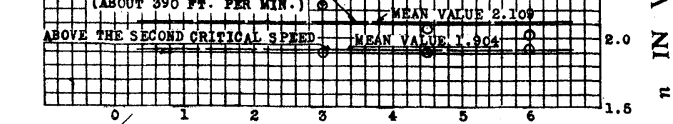
DRAUGHT IN INCHES

(b) CURVES OF $n$ IN $\mathbf{V}^{n}$ AGAINST DRAUGHT.

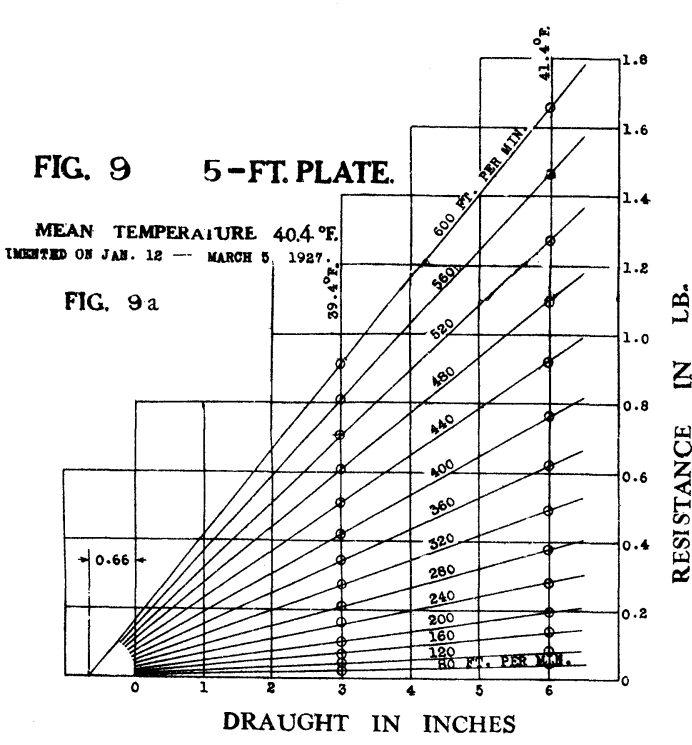

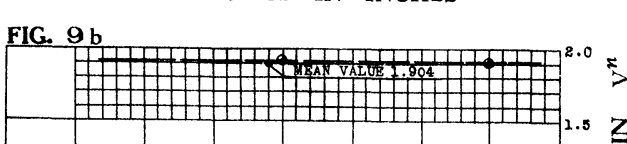
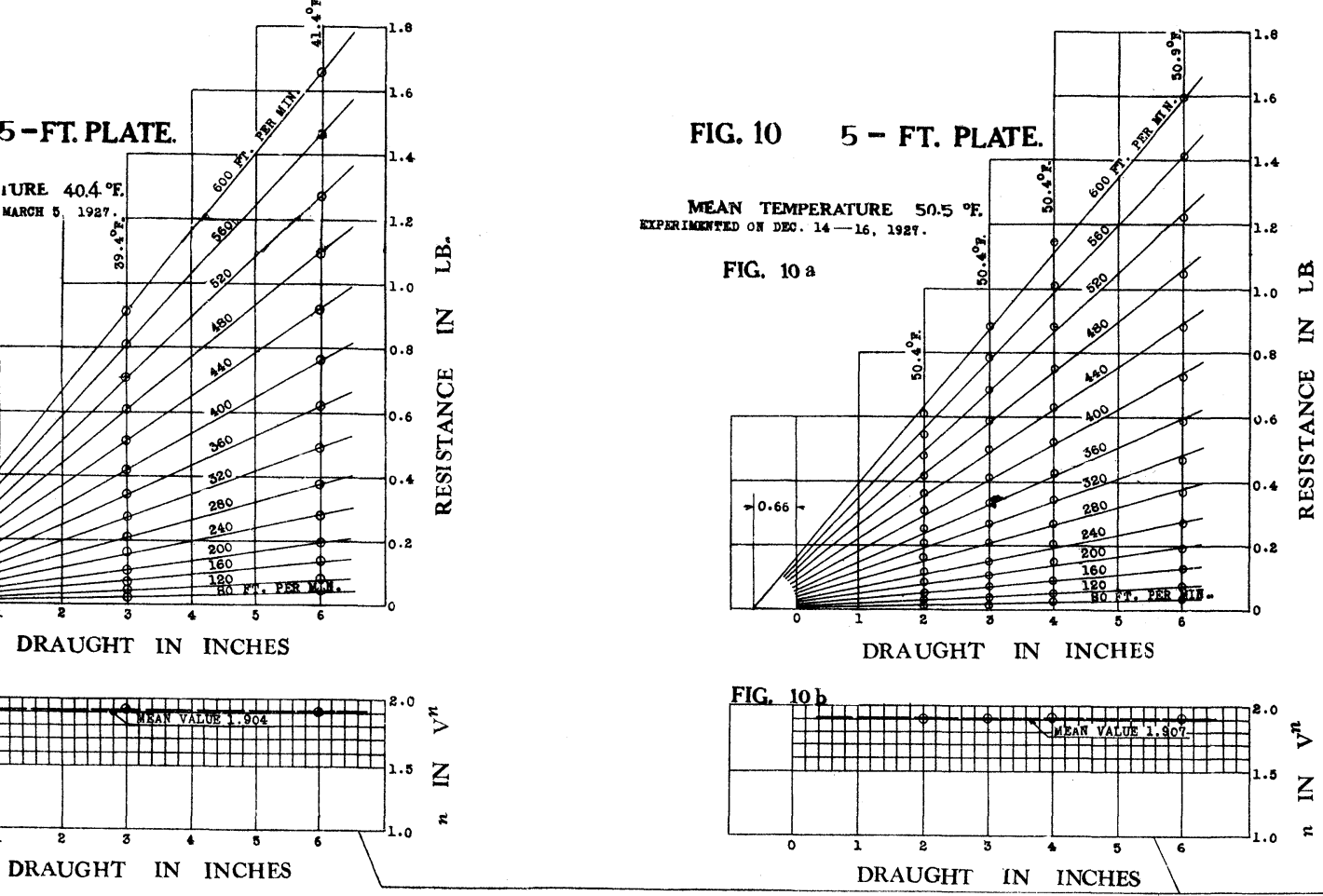

${ }_{\text {DRAUGHT IN INCHES }}^{2} \overbrace{}^{2}$

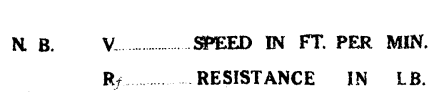

FIG. 13 8-FT. PLATE.

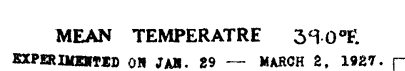

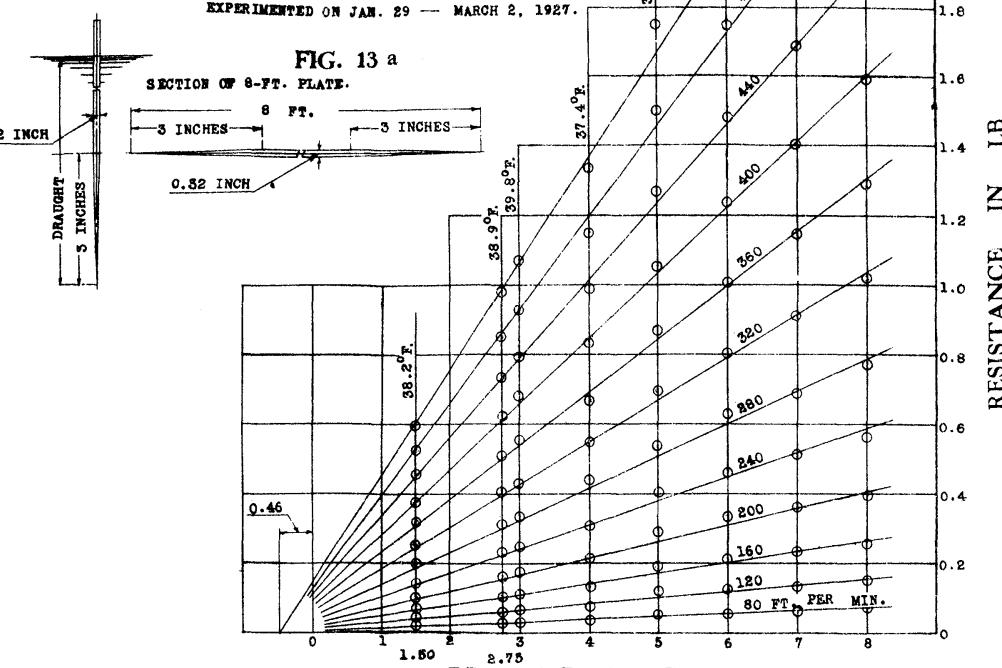

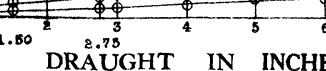
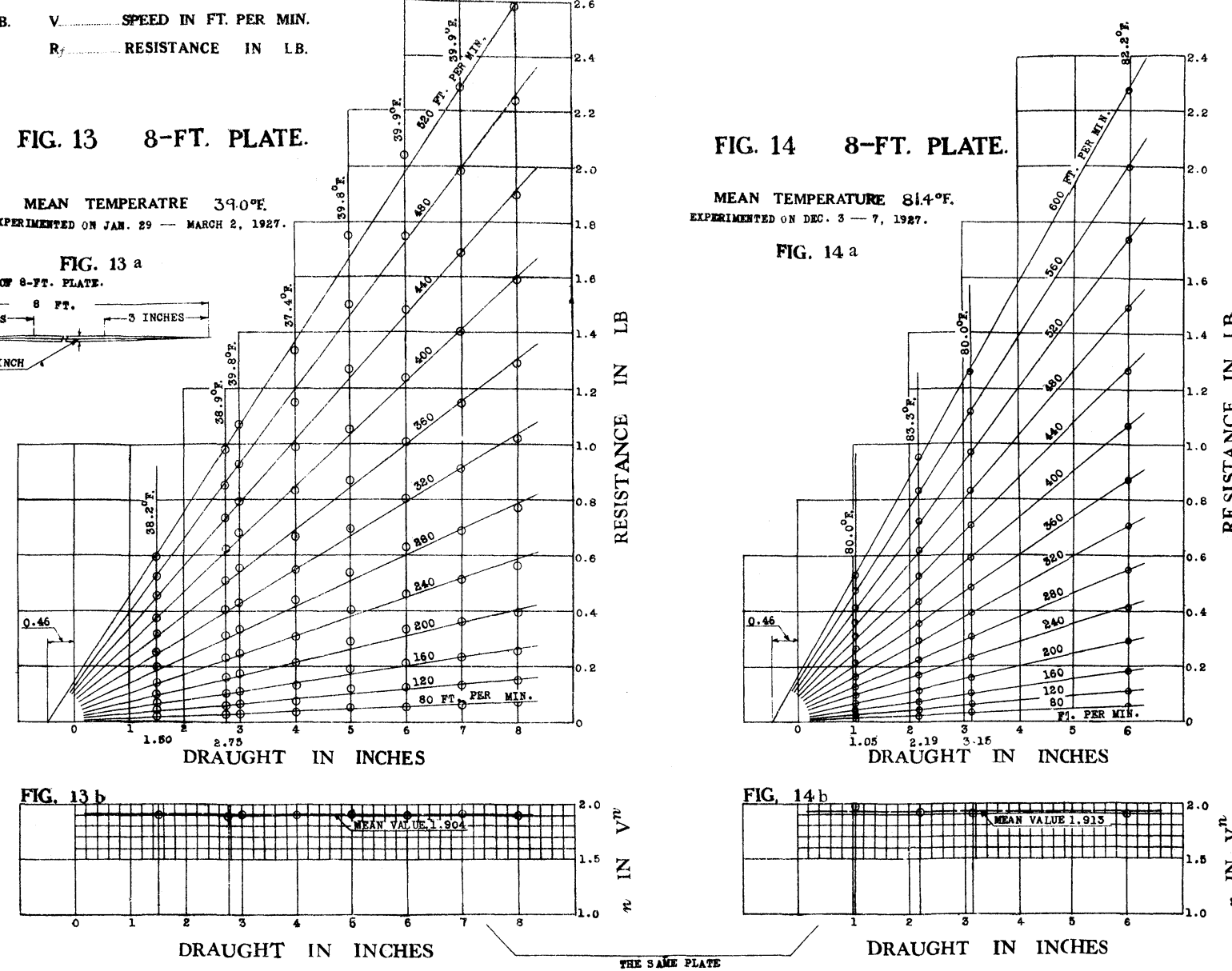

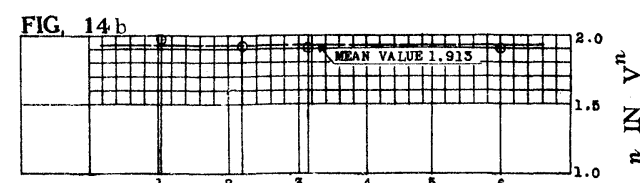
DRAUGHT IN INCHES
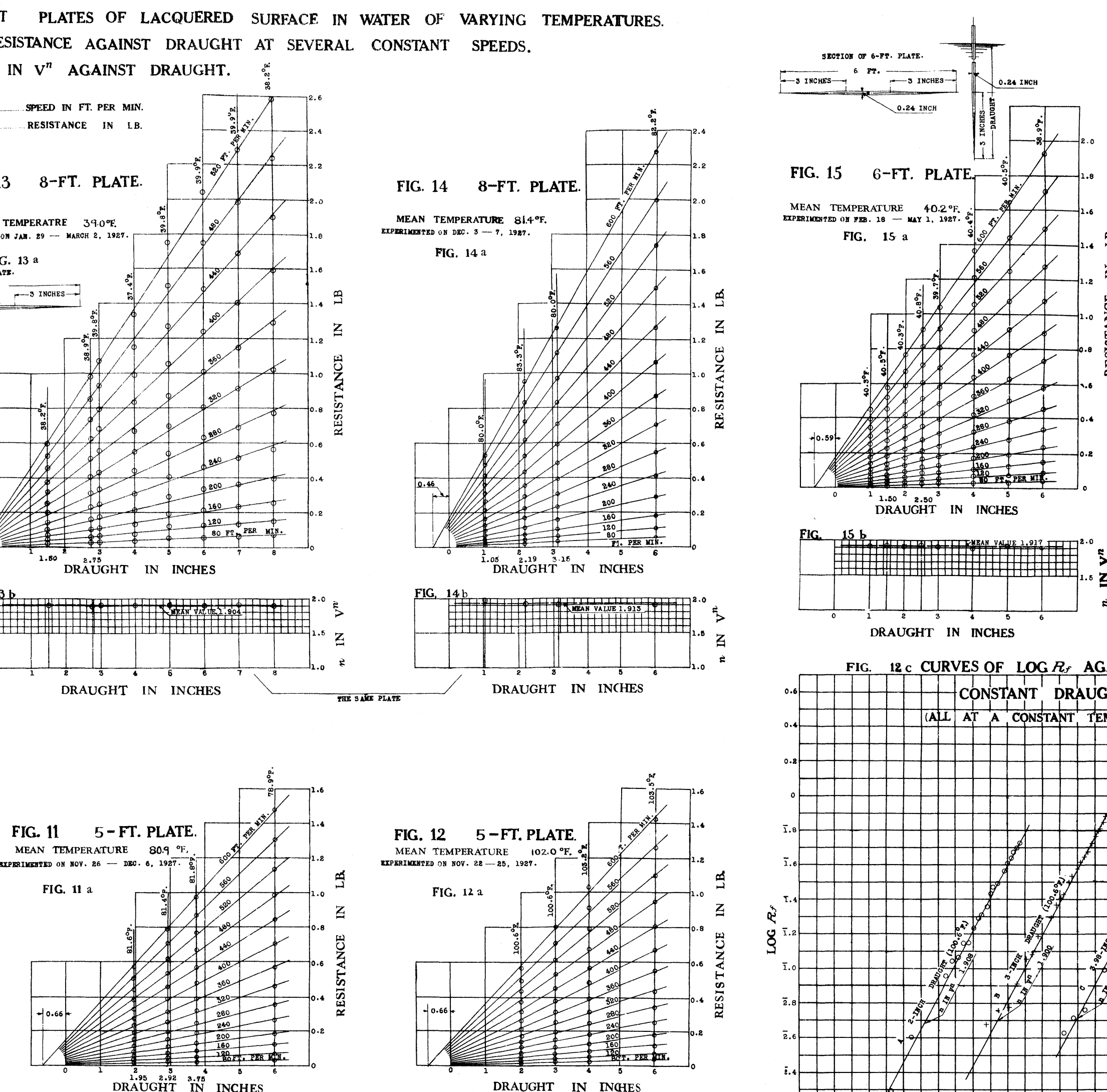

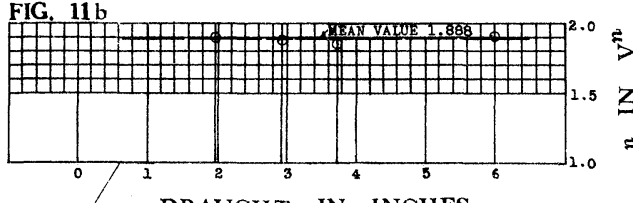

FIC. $12 \mathrm{~b}$

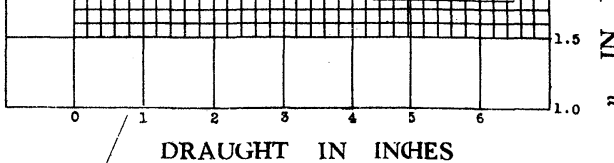

Fla $15 \mathrm{~b}$

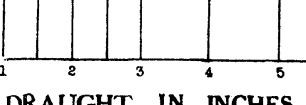

$2=$

FIG. 12 CURVES OF LOG $R_{f}$ AGAINST LOG 2 AT SEVERAL

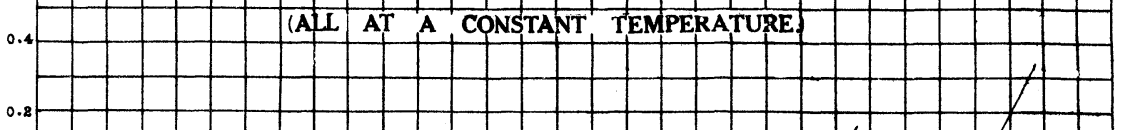

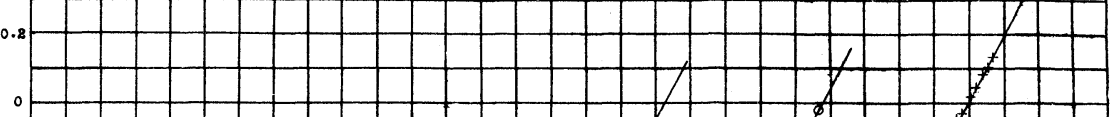

PLATE III

Q

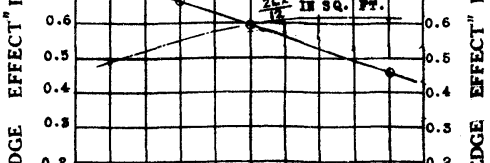

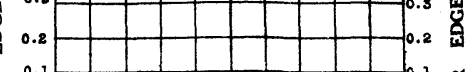

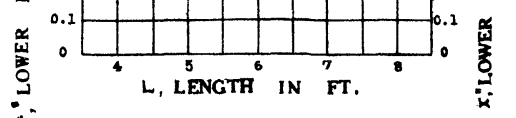

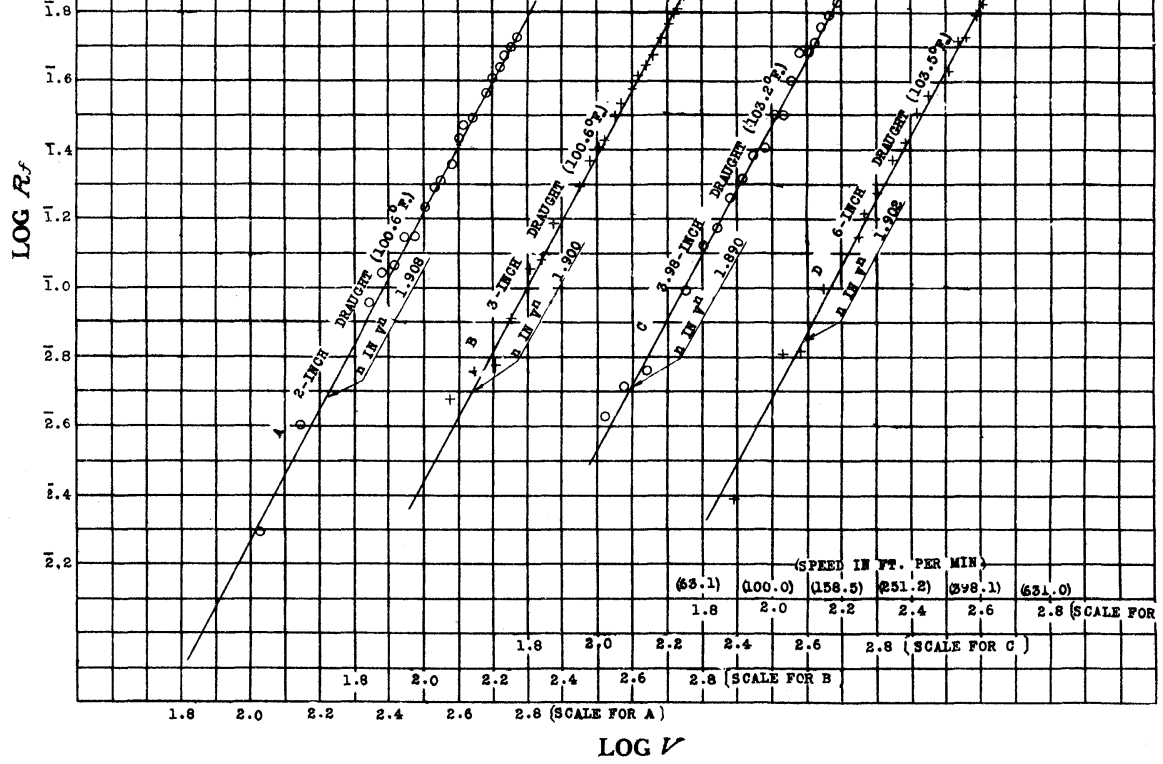




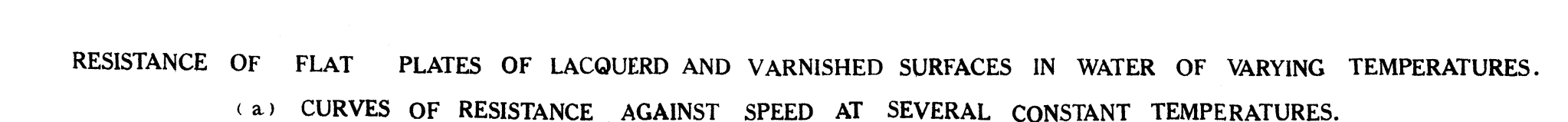
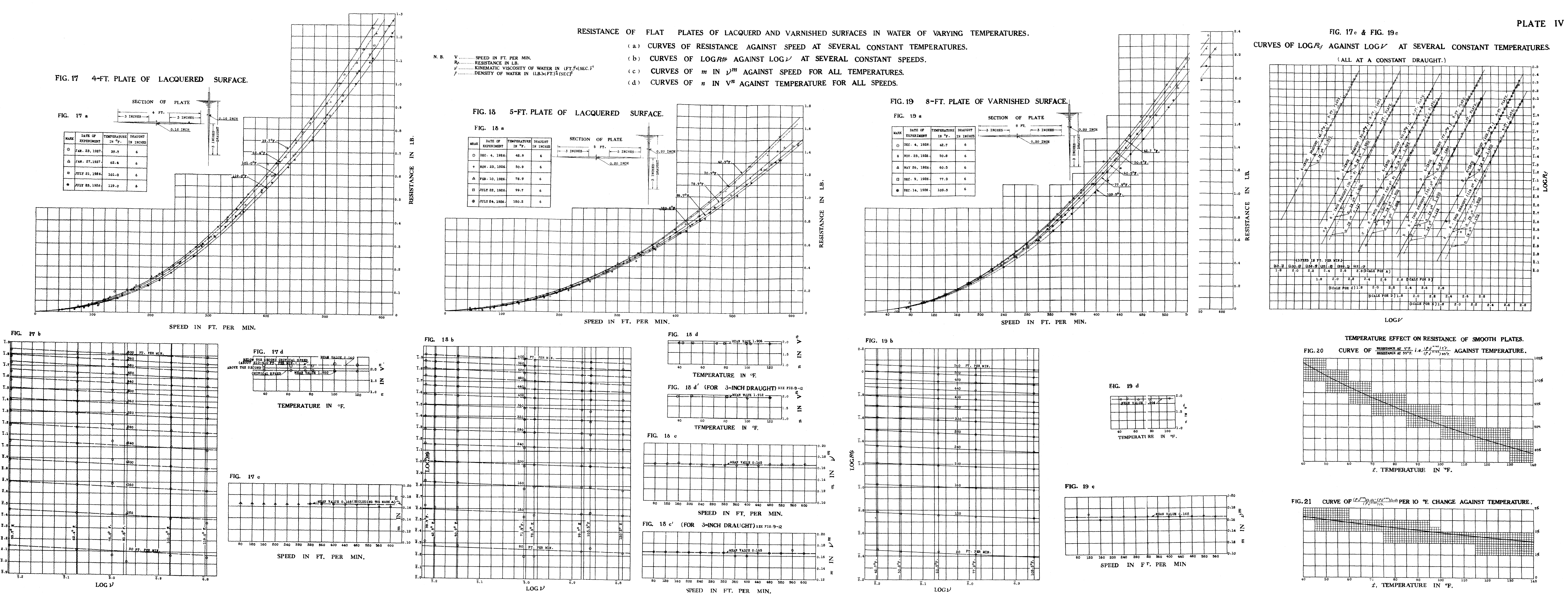

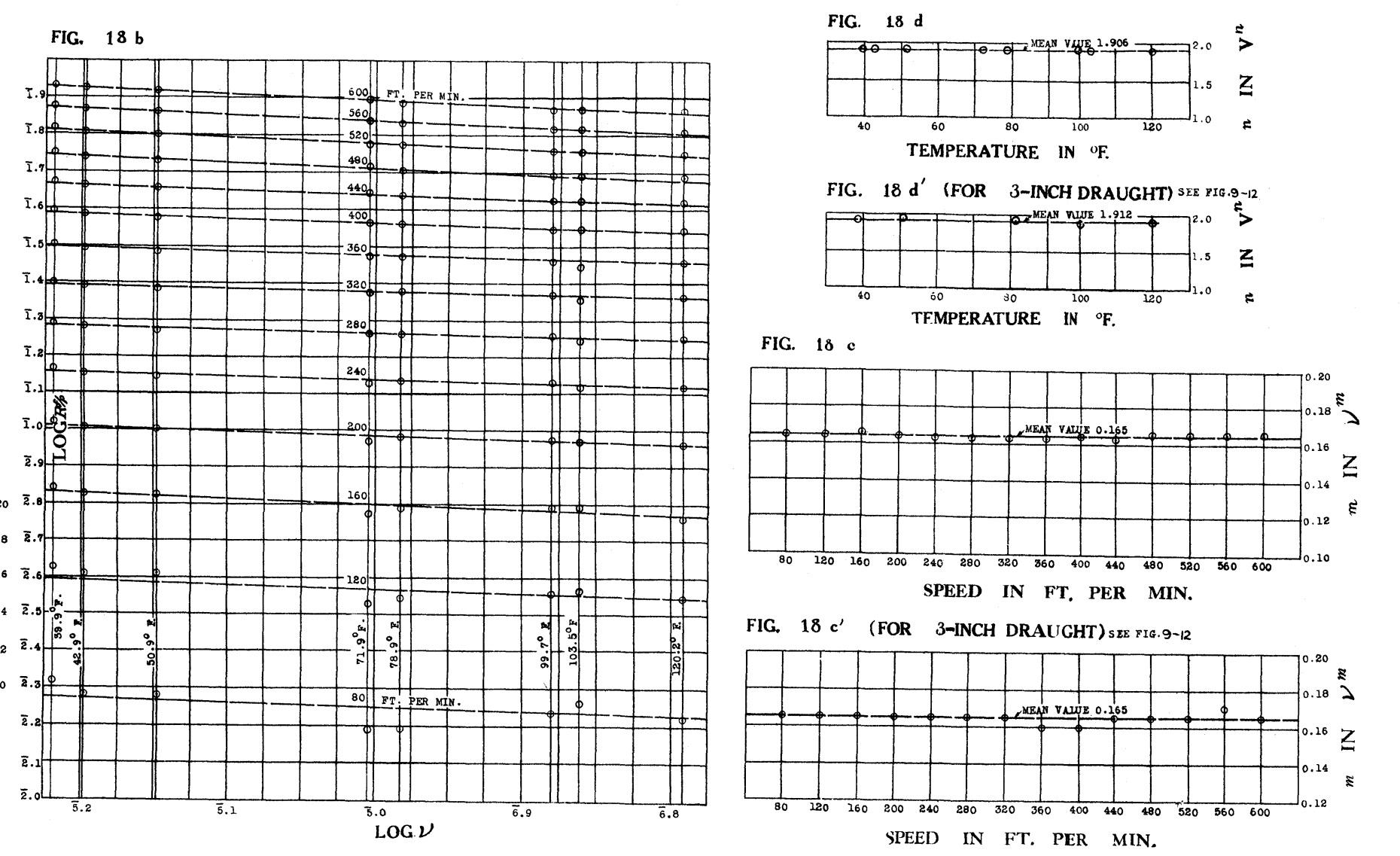

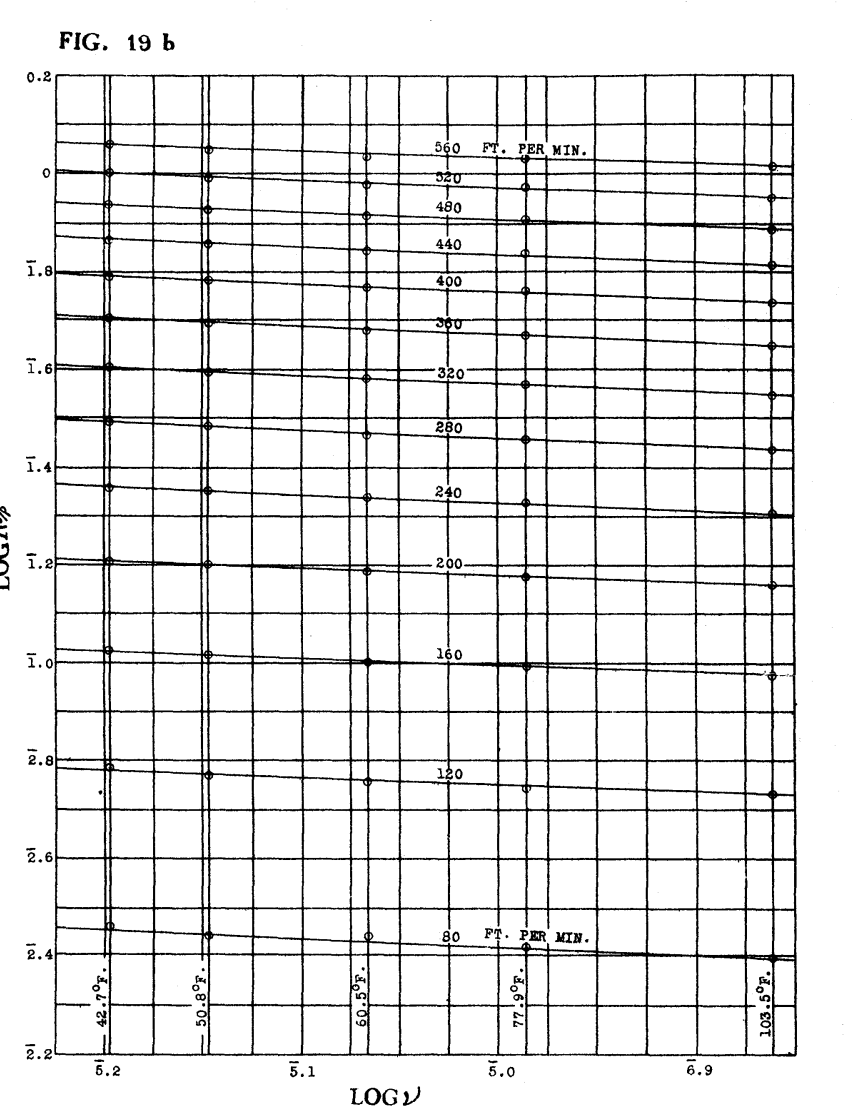

Hec is

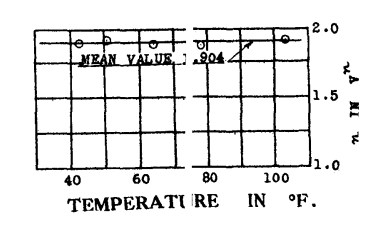

FIC. 19 e

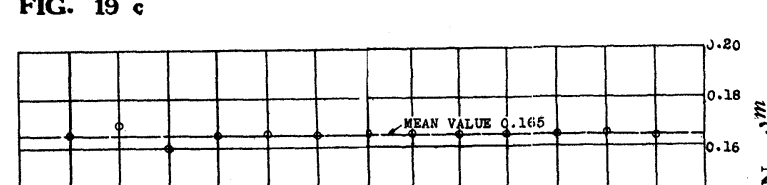

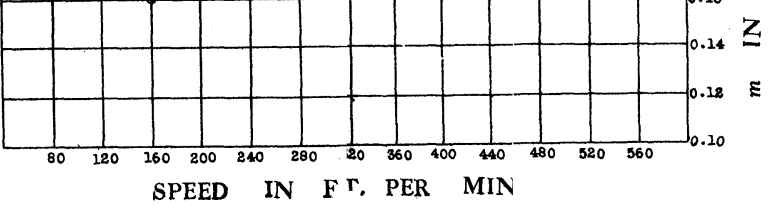

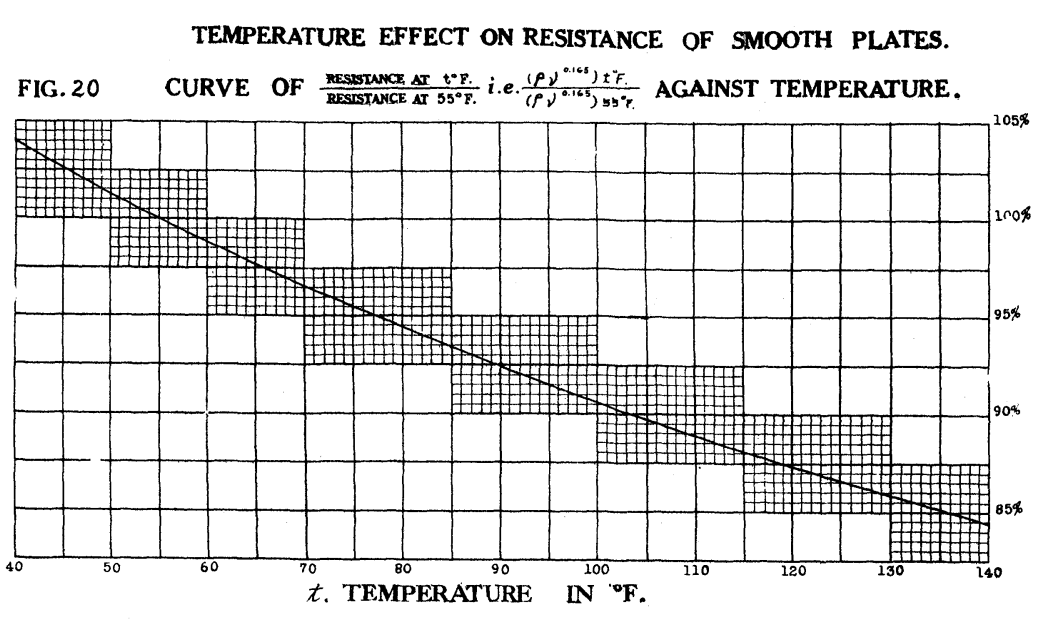

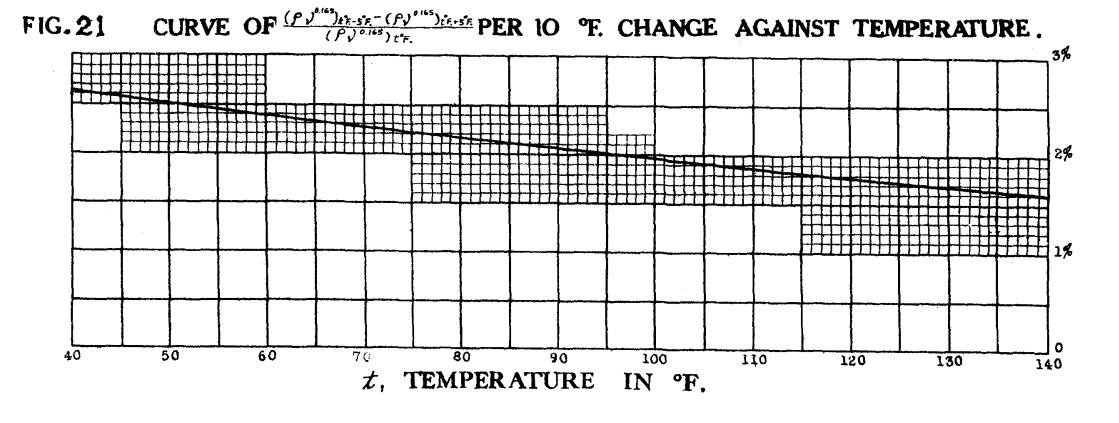




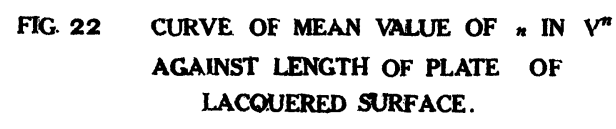

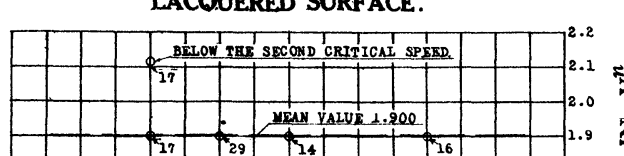
H.H.".

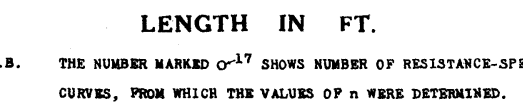

FIG. 23a 4-FT. PLATE OF LACGUERD SURFACE, ए।

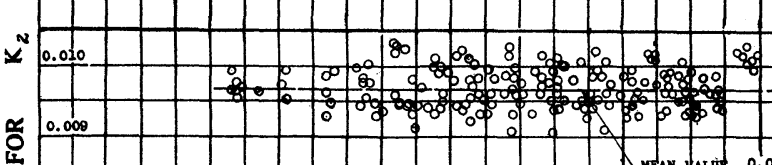

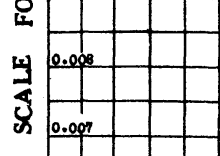

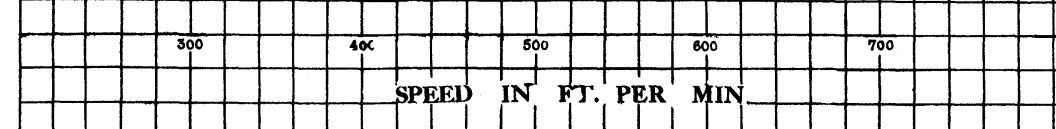

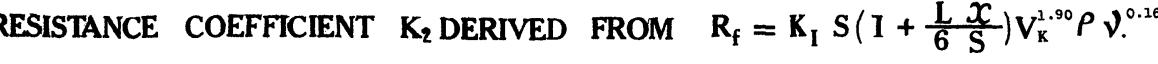

CURVES OF $\mathrm{K}_{2} \mathrm{AGANST}$ SPEE

(b) CURVES OF $\mathrm{K}_{2}$ ACAANST ( SPEBD $\times$ DRAUAHT)

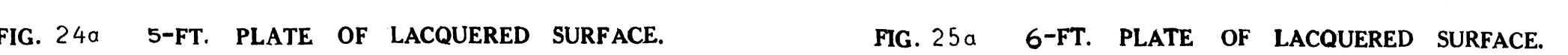
\begin{tabular}{|c|c|c|c|}
\hline & & \\
\hline
\end{tabular}

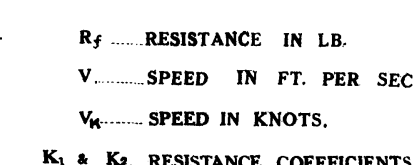

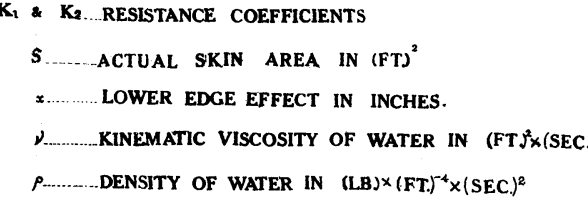

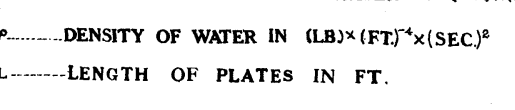

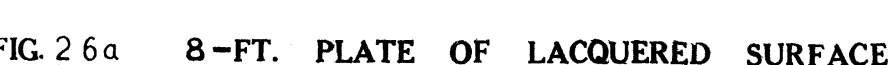

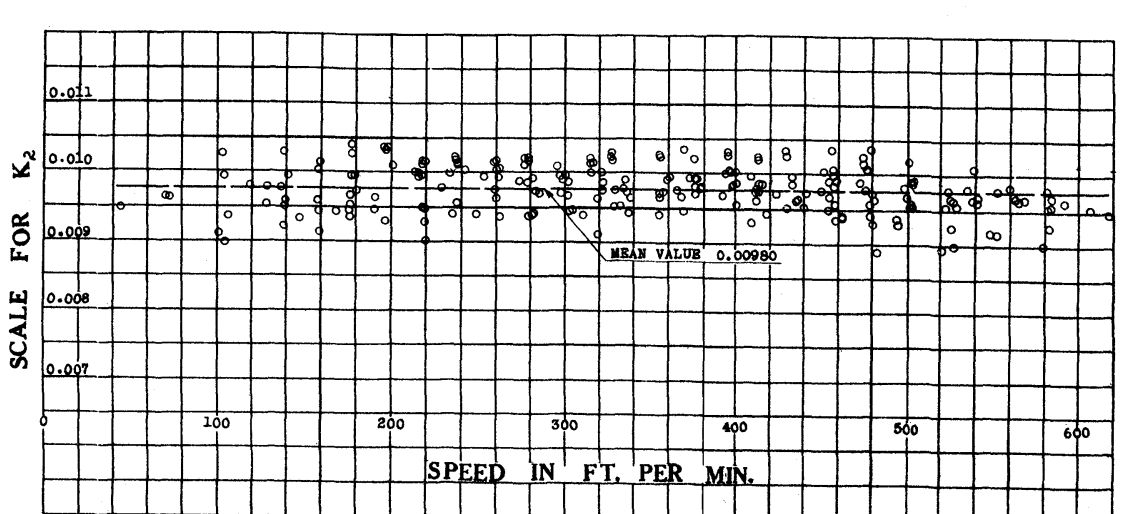

5-FT. PLATE OF LACQUERED SURFACE

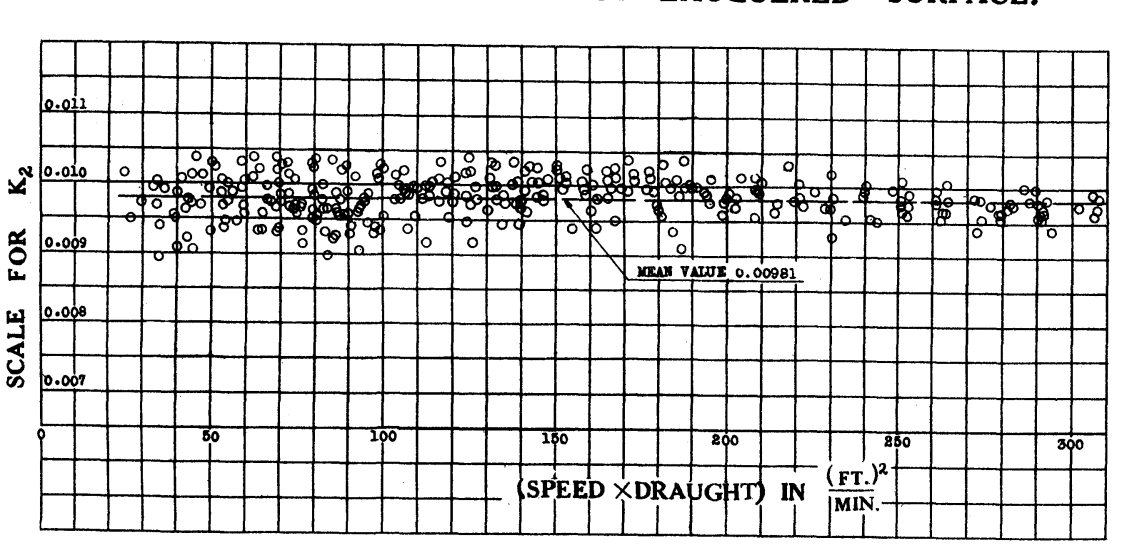

Fic. 27 CURVE OF MEAN VAlUE OF $\mathrm{K}$

FiG. 266 B-FT. PLATE OF LACOUERED SUPFACE

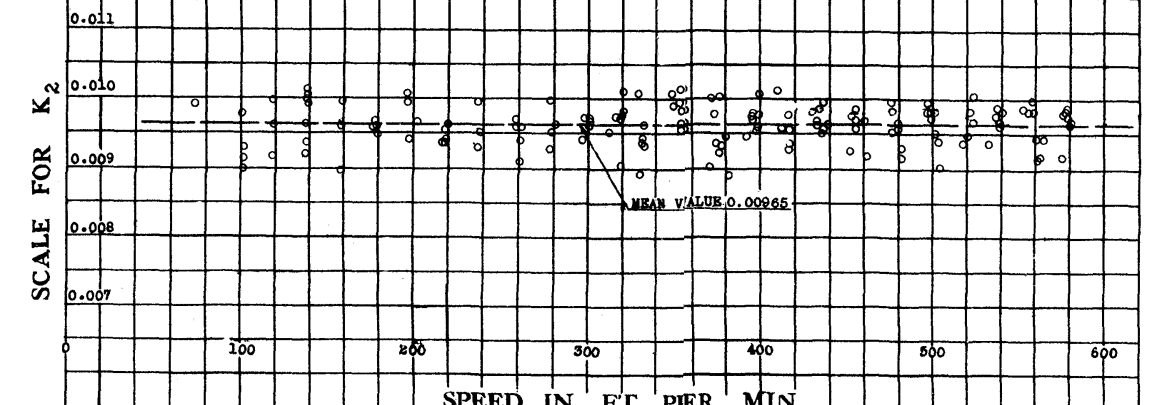

AGANST LENG TH OF PLAT
(LACQUEREI SURFACE)

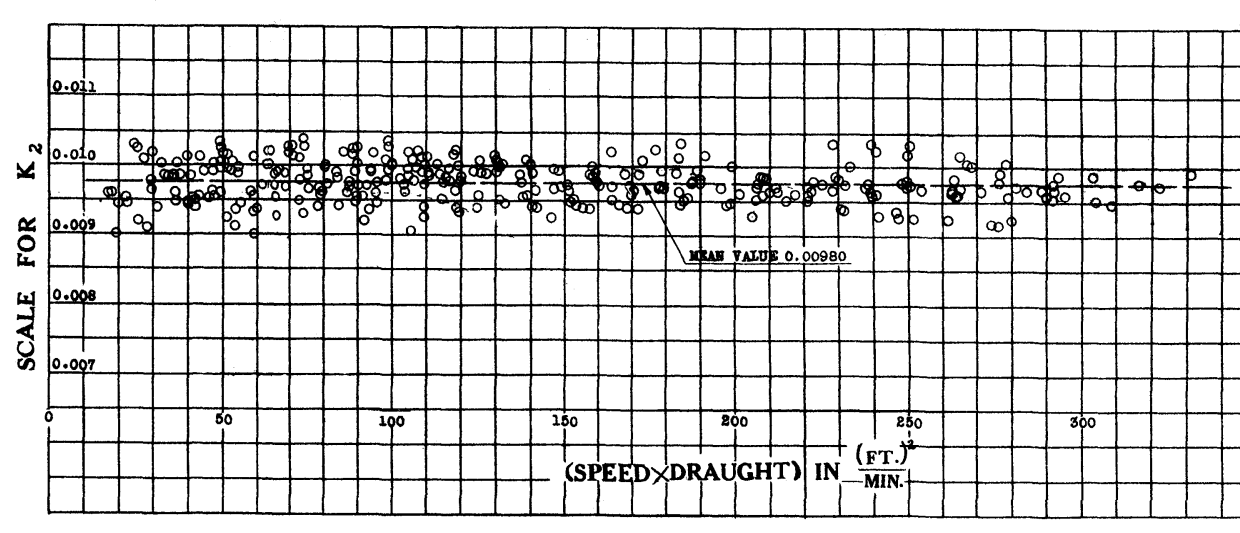

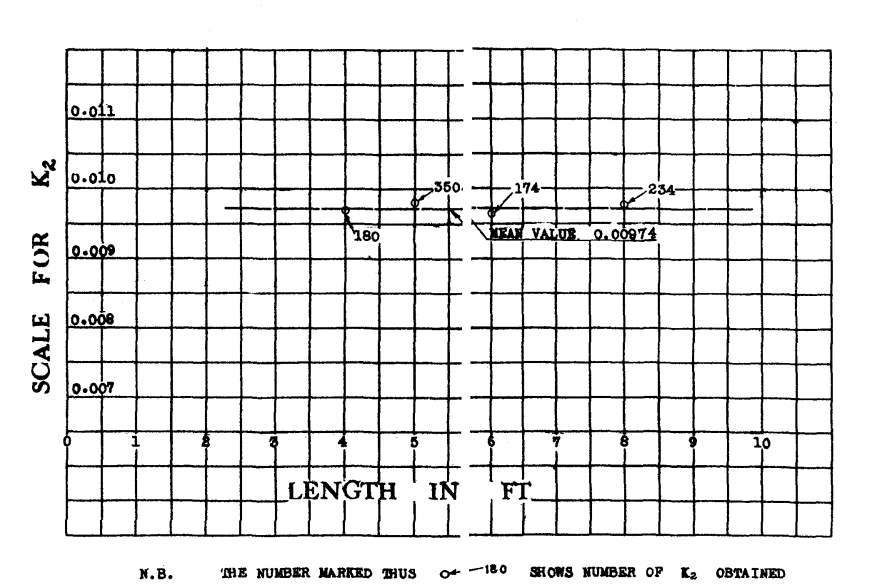

ing

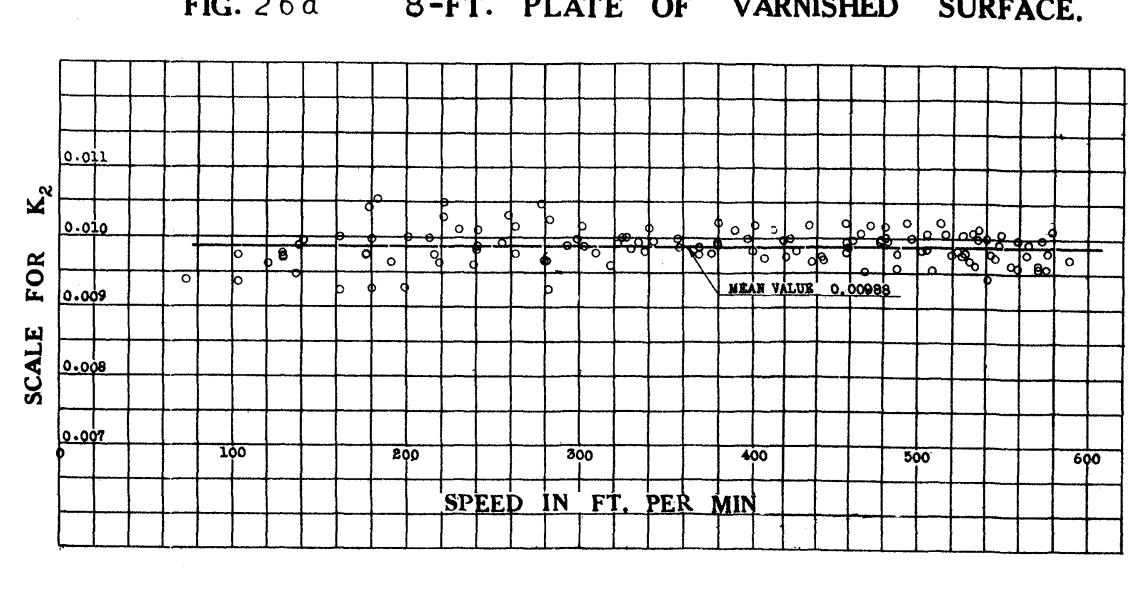

We

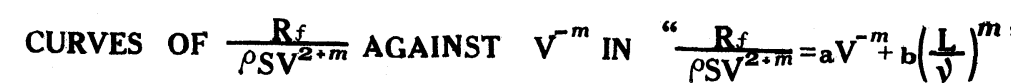

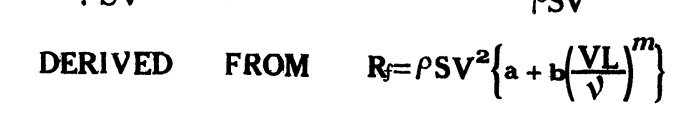

FIC. 28 a

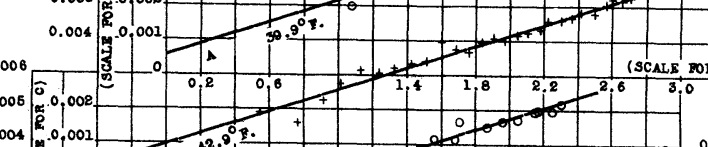

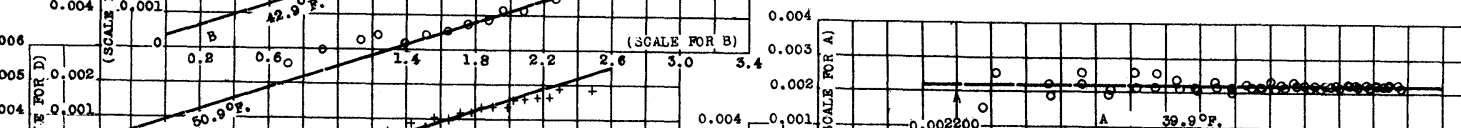

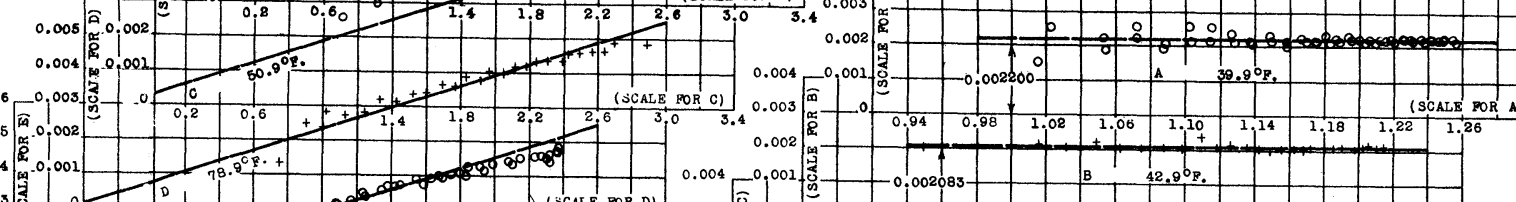

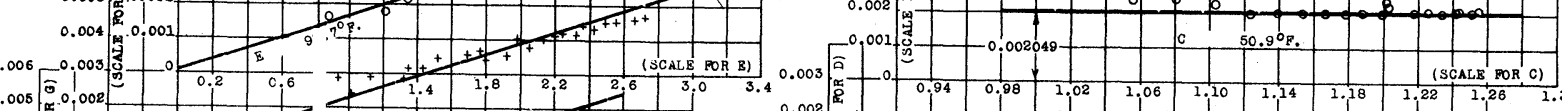

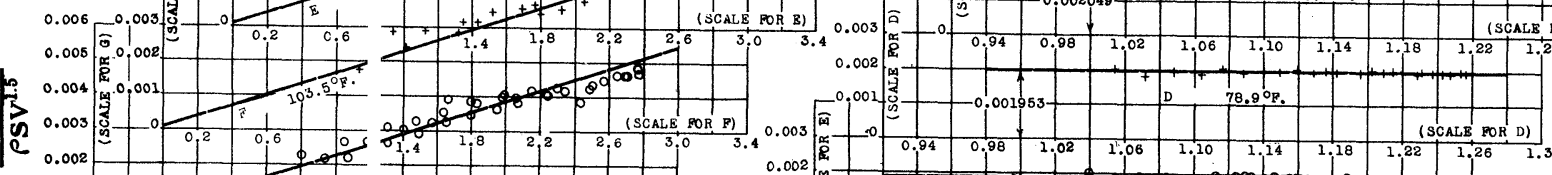

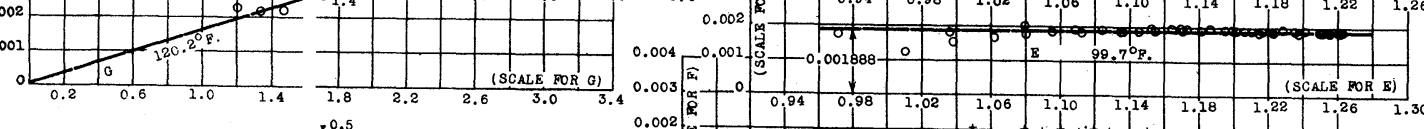

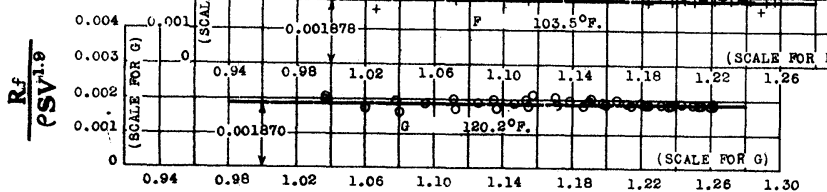

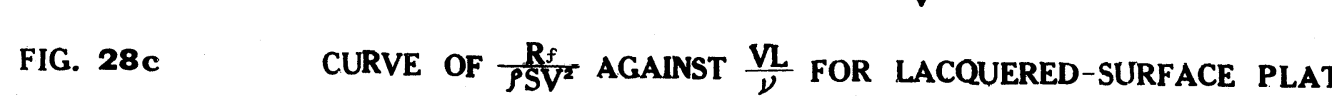

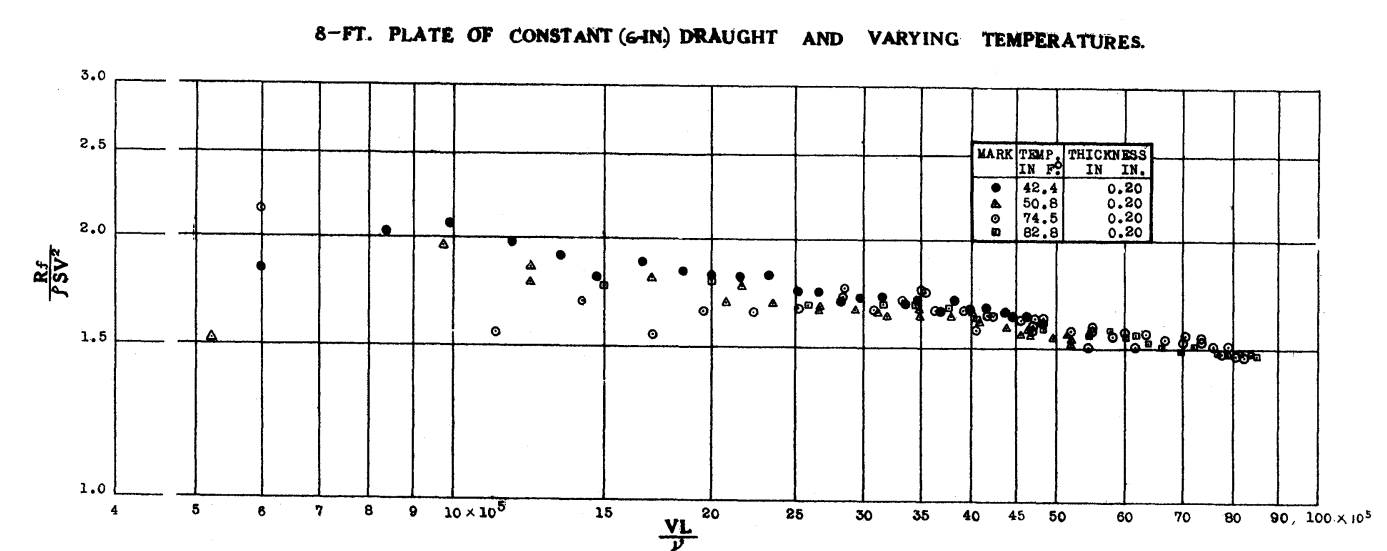



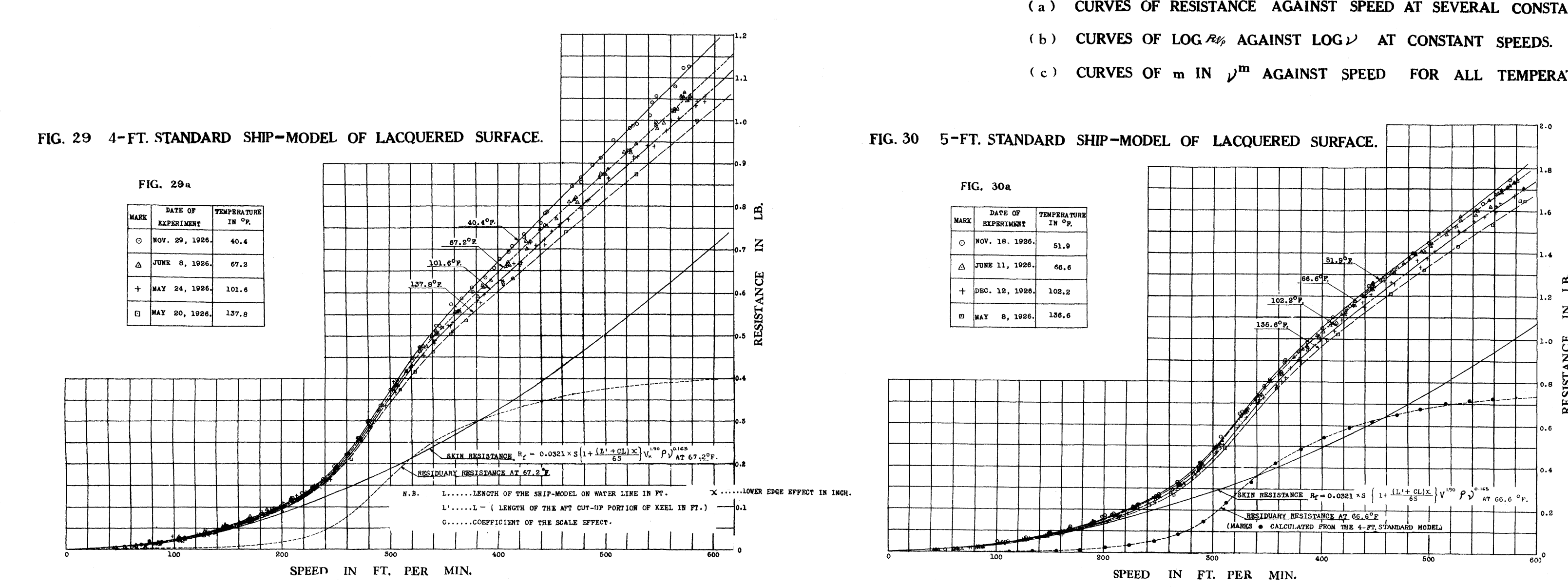

$$
\text { 渵语 }
$$

FIC. $29 \mathrm{~b}$ $\mathrm{r}$
$\mathrm{r}: 2$

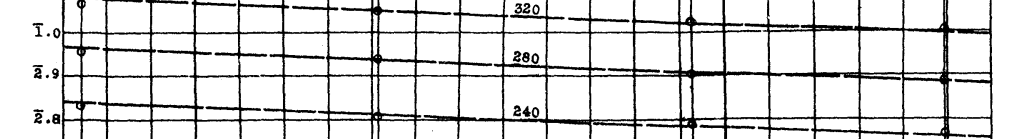
: :

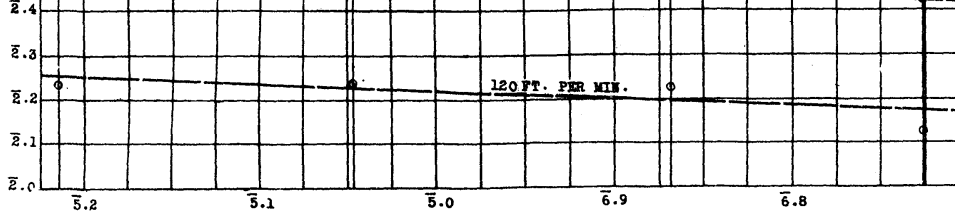

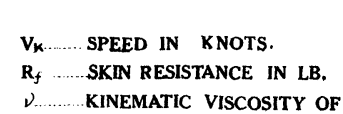
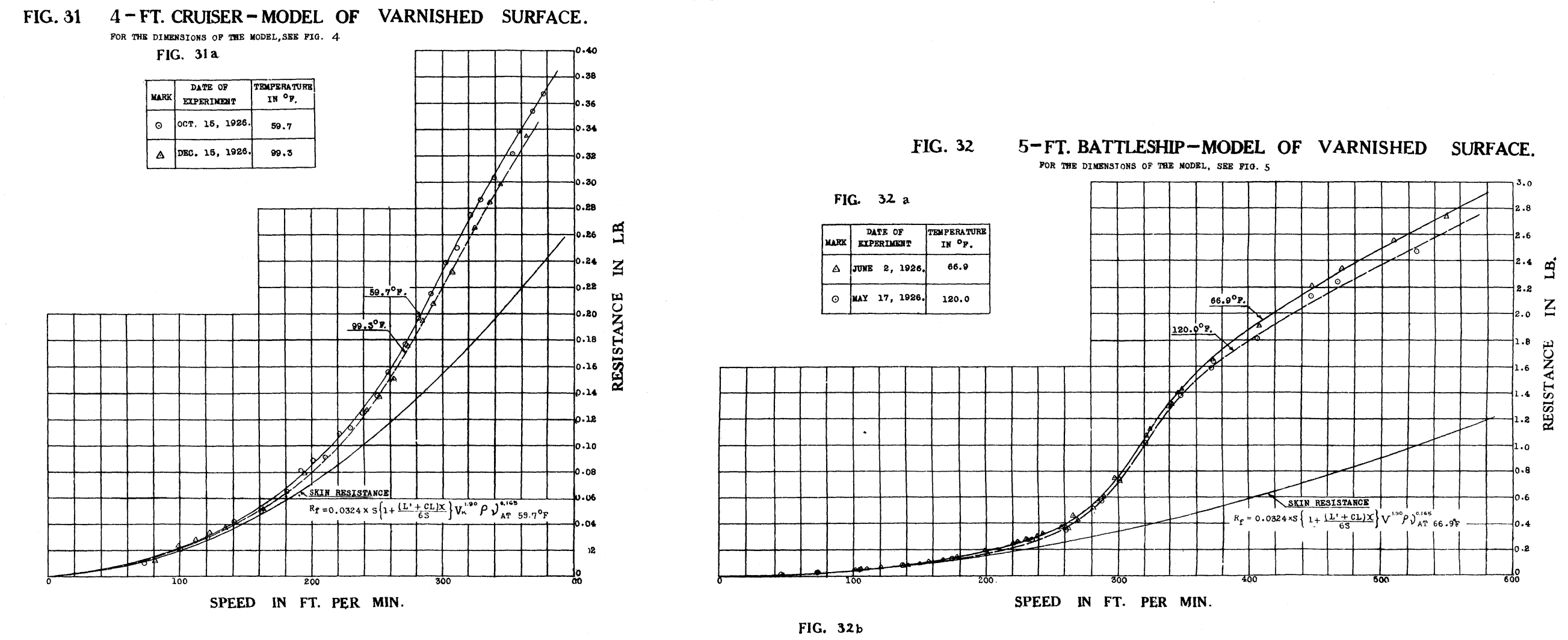

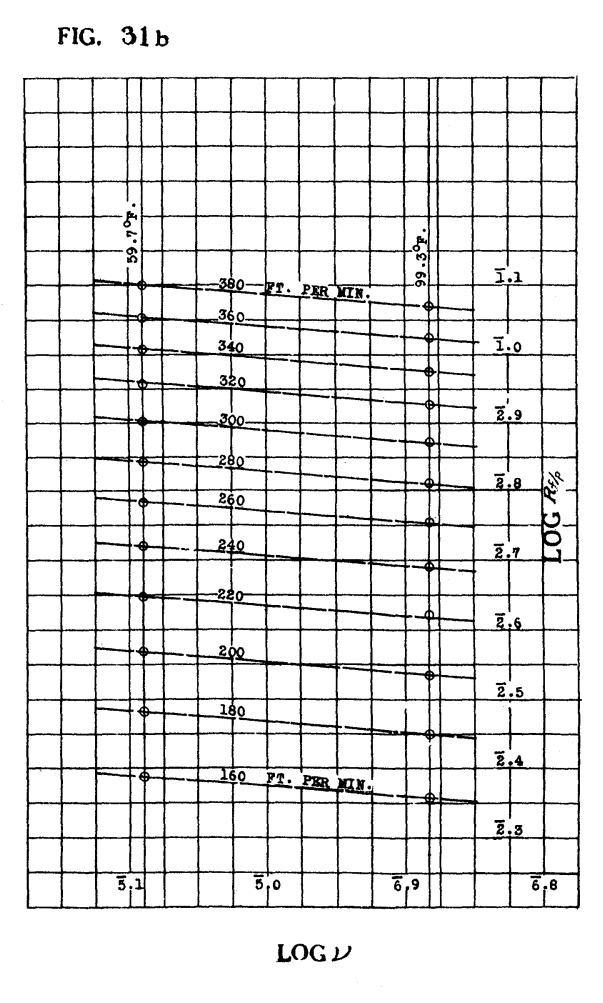

HC. 310

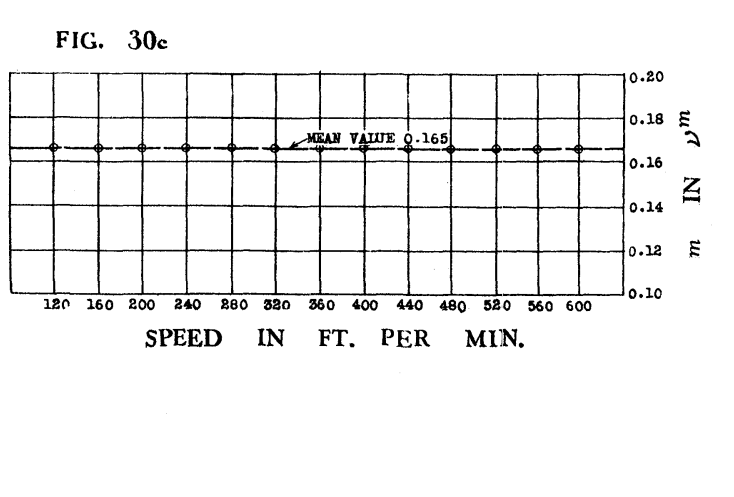

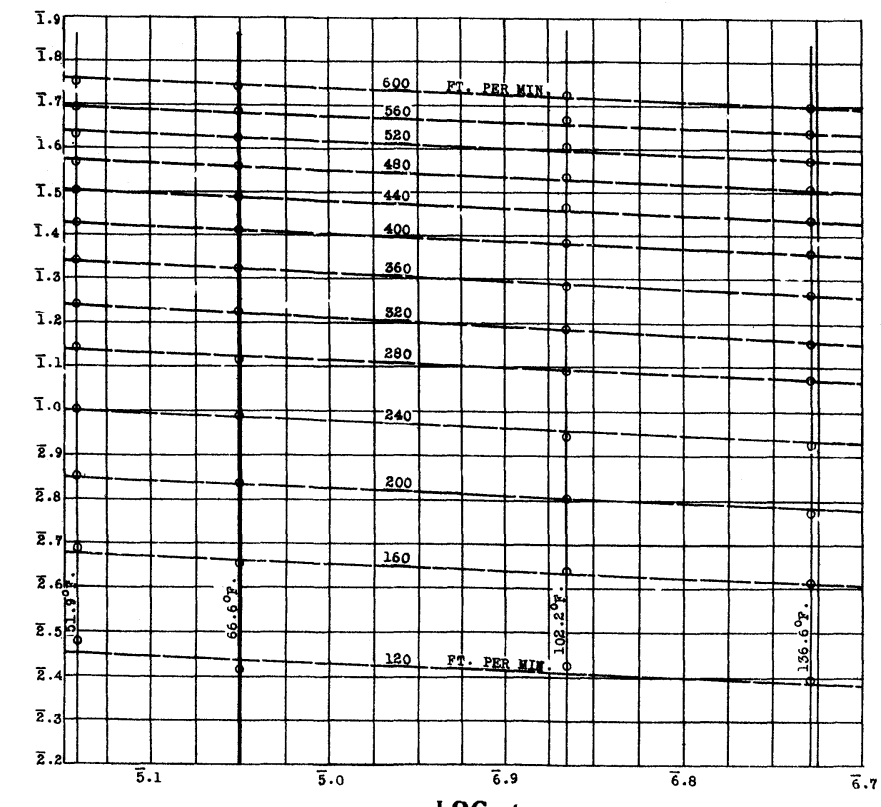

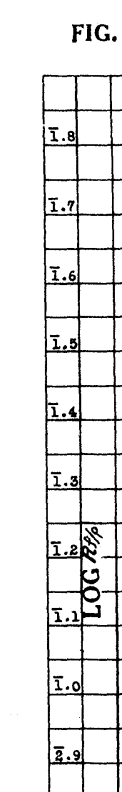

id

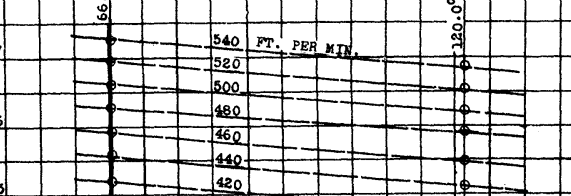

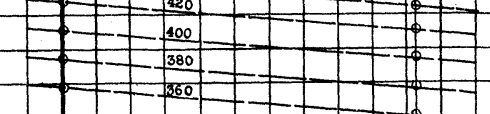

Fic. 3..

$+x_{n=1}$

:

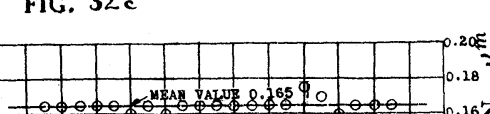

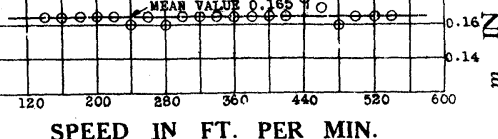


FiG. 34 8-FT. PLATE OF LACQUERED SURFACE.

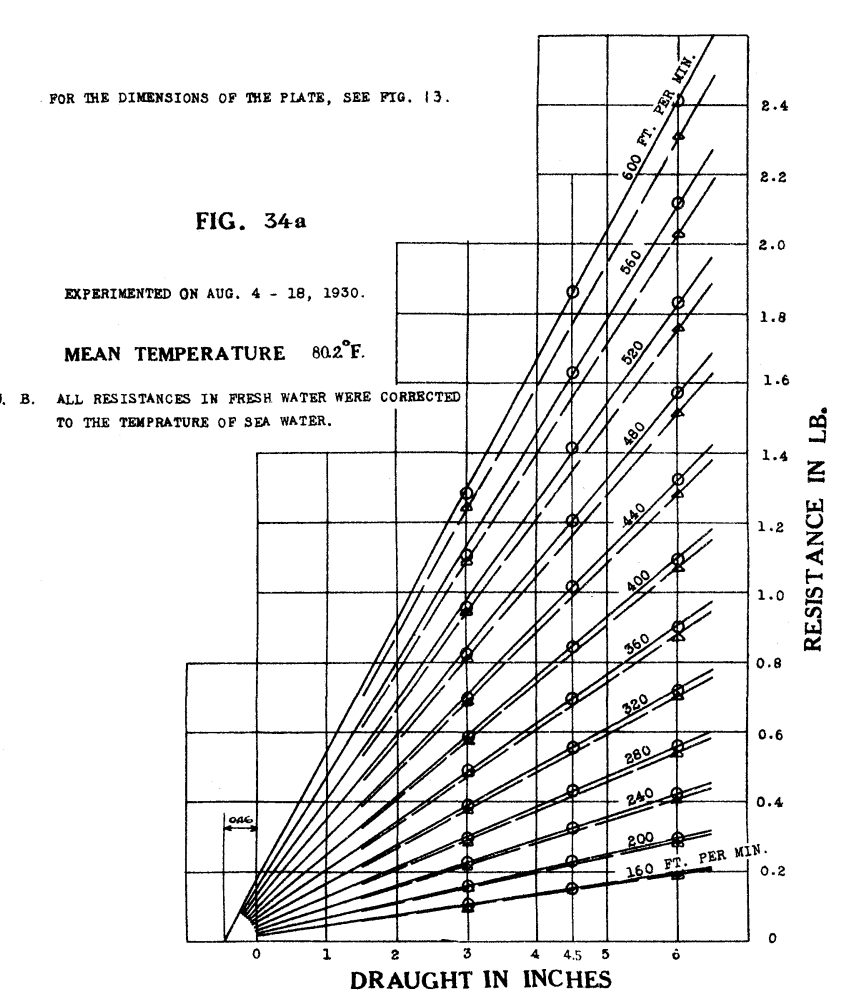

Fic. $34 \mathrm{~b}$

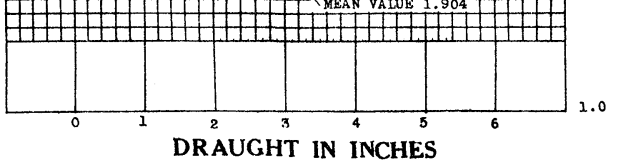

FIG. 33 8-FT. PLATE OF ROUGH SURFACE.
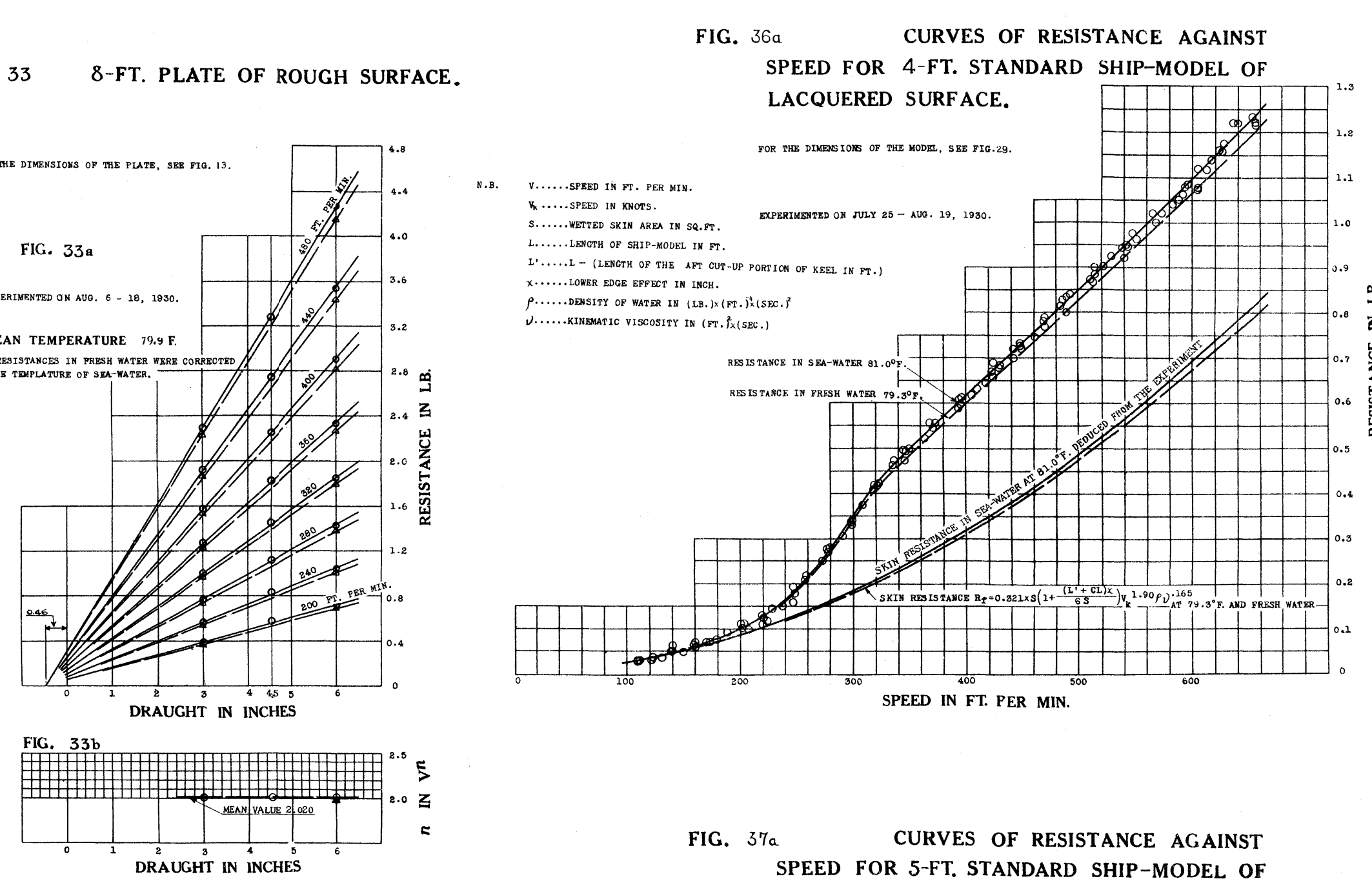

PERCENTAGE INCREASE OF RESISTANCE DUE TO SEA-WATER,

FIG. 34c 8-FT. PLATE OF LACQUERED SURFACE.

FIG. 33c 8-FT. PLATE OF ROUGH SURFACE.

FiG. 34d 8-FT. PLATE OF LACQUERED SURFACE AT GIN. DRAUGHT. F-FT. 36 STANDARD MODEL OF LACQUERED SURFACE.

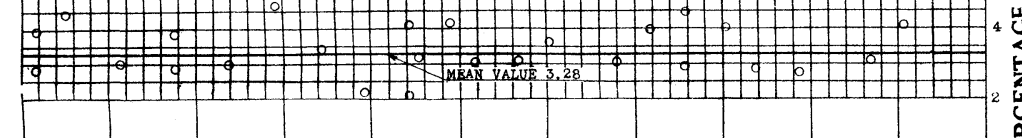

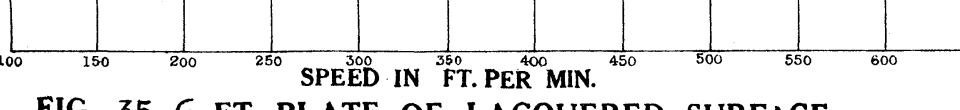

FiG. 35 6-FT. PLATE OF LACQUERED SURFACE.

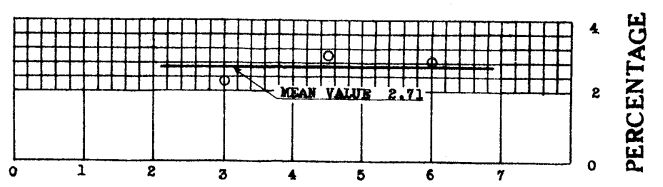

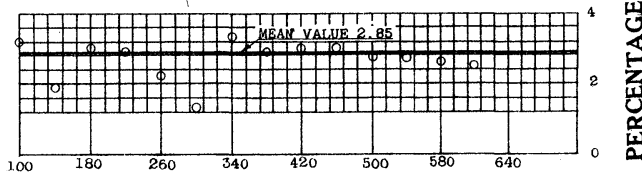

FIC. $3.7 \mathrm{~T}$.

STANDARD MODEL OF LACQUERED SURFACE.

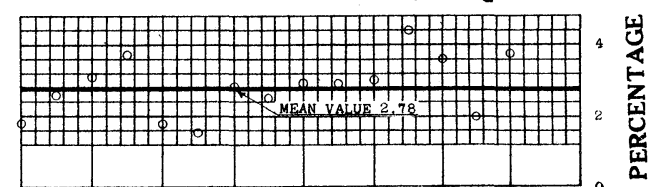

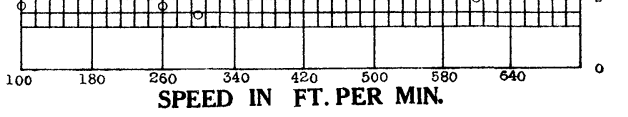

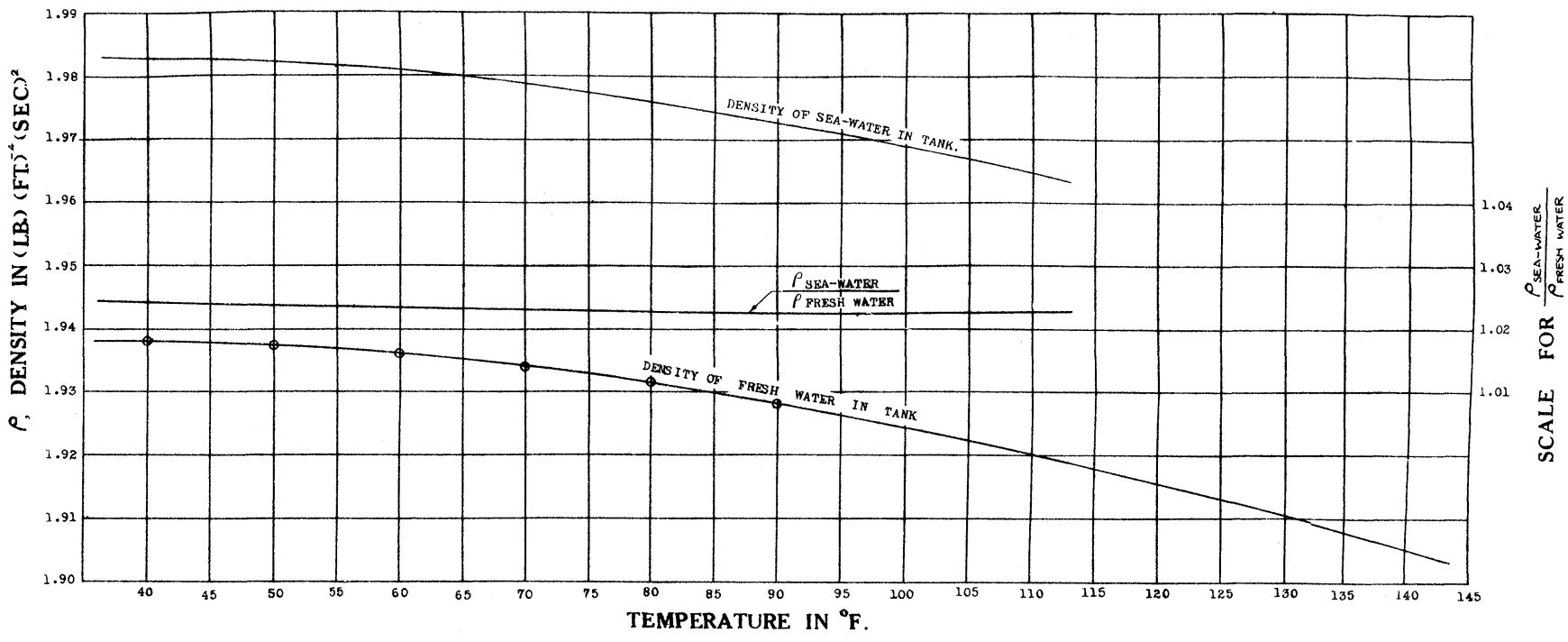

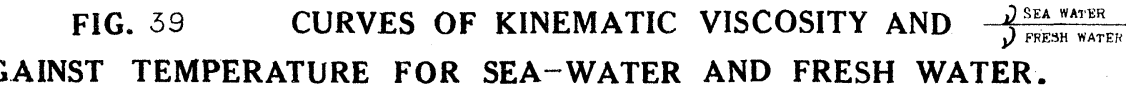

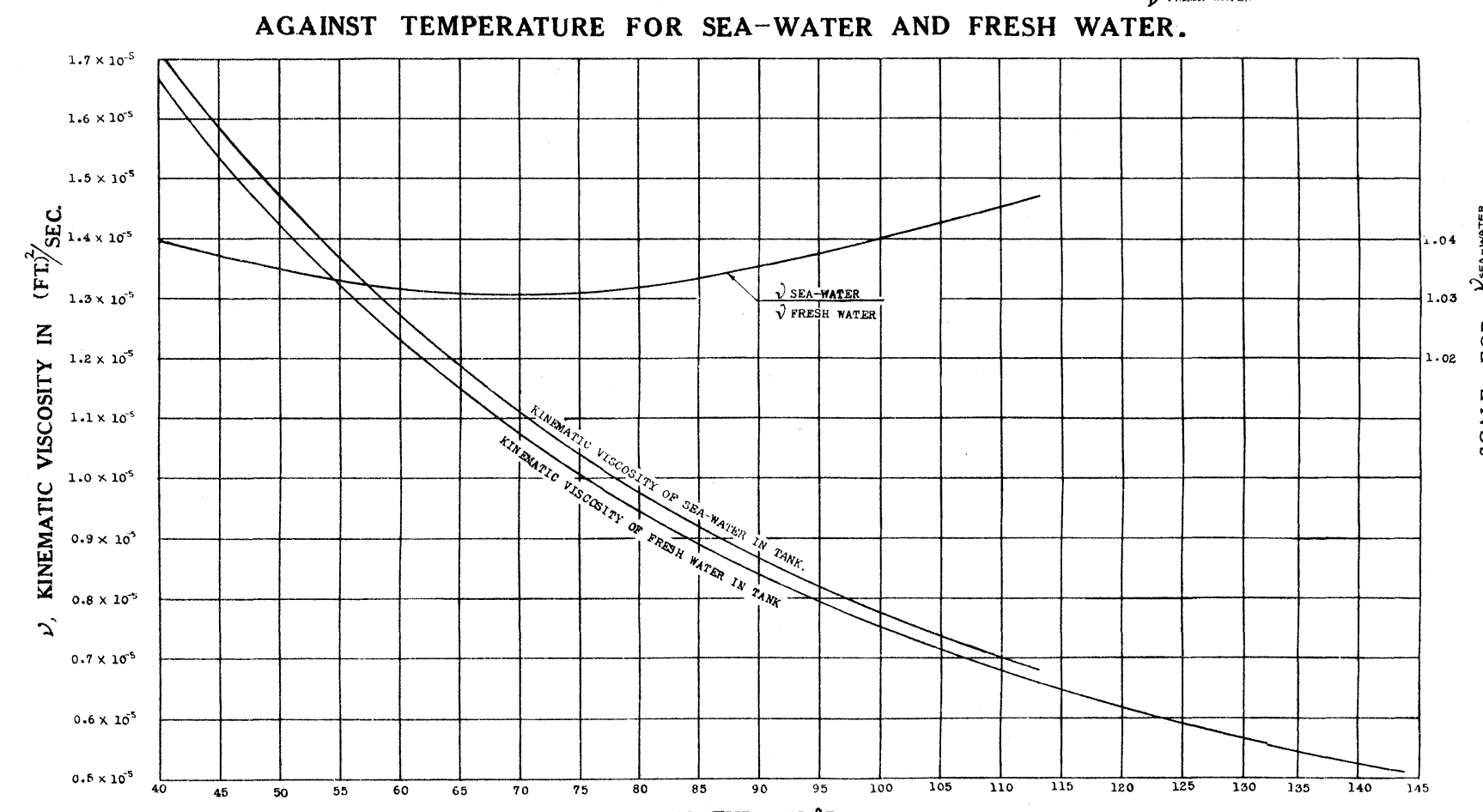

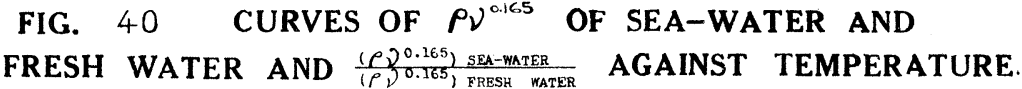

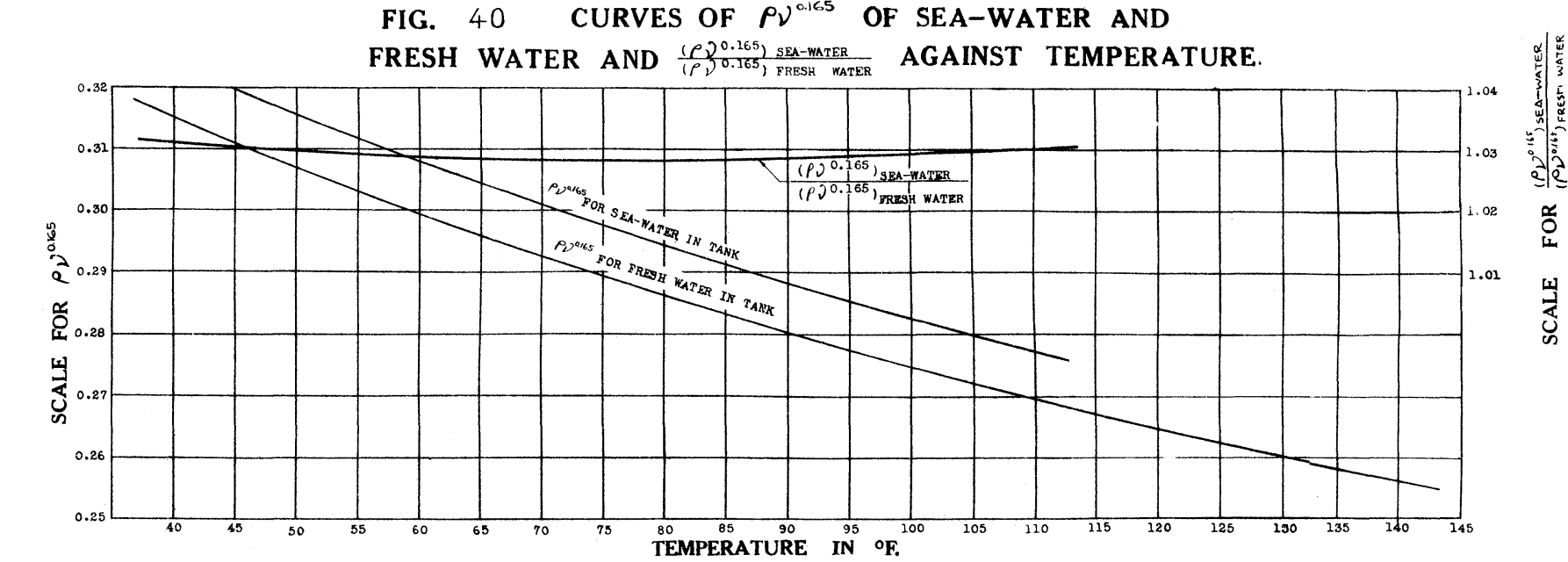


FIG. 67 THICKNESS 0.197 INCH.

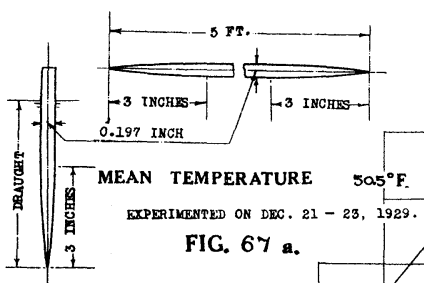

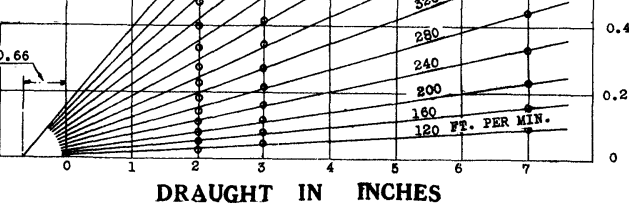

Fll.67 b.

$\sum_{\text {DRAUGHT IN INCHES }} \sum^{\circ}$

FIG. 68 THICKNESS $0.315-$ INCH.
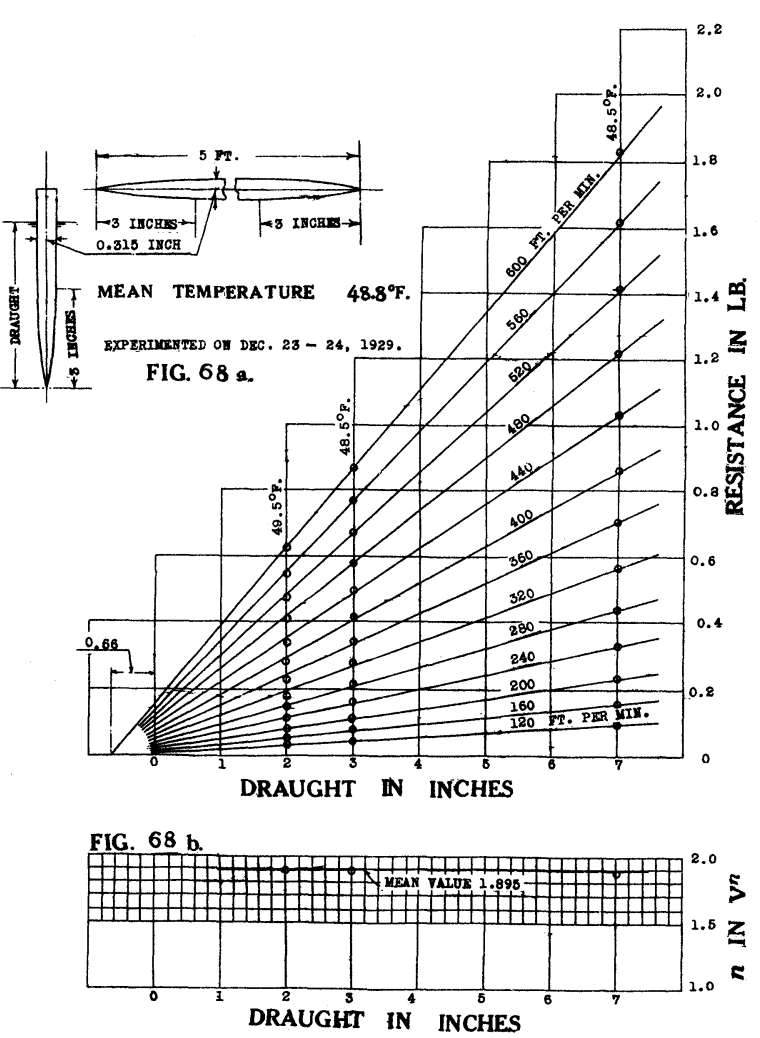

FIG. 70 THICKNESS $0.591-$ INCH

\begin{abstract}
FIG. 69 THICKNESS 0.394 -INCH
\end{abstract}
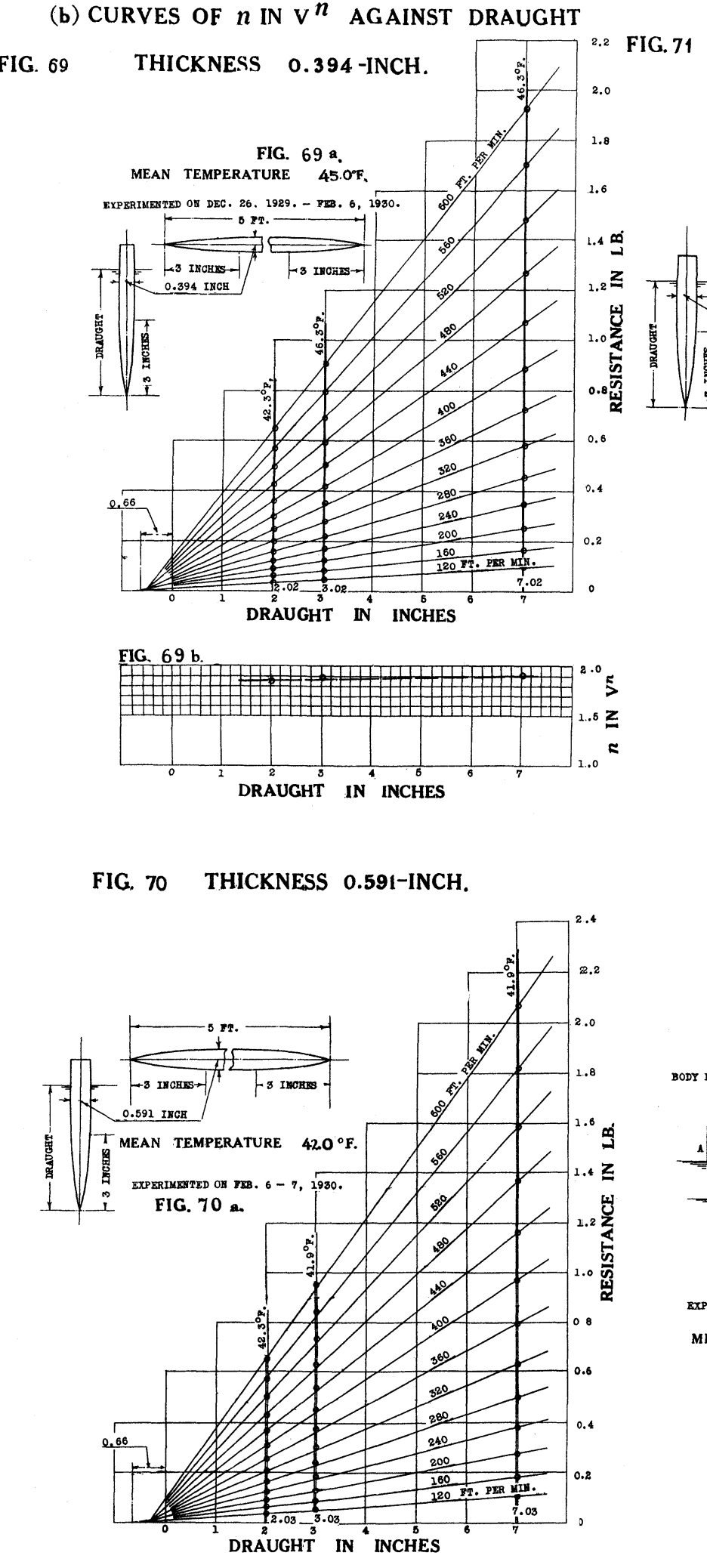

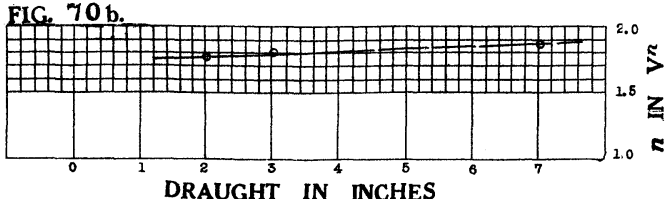

FIG. 76 CURVES OF LOG $R$ AGAINST LOG $V$ FOR 4-FT PLANKS.

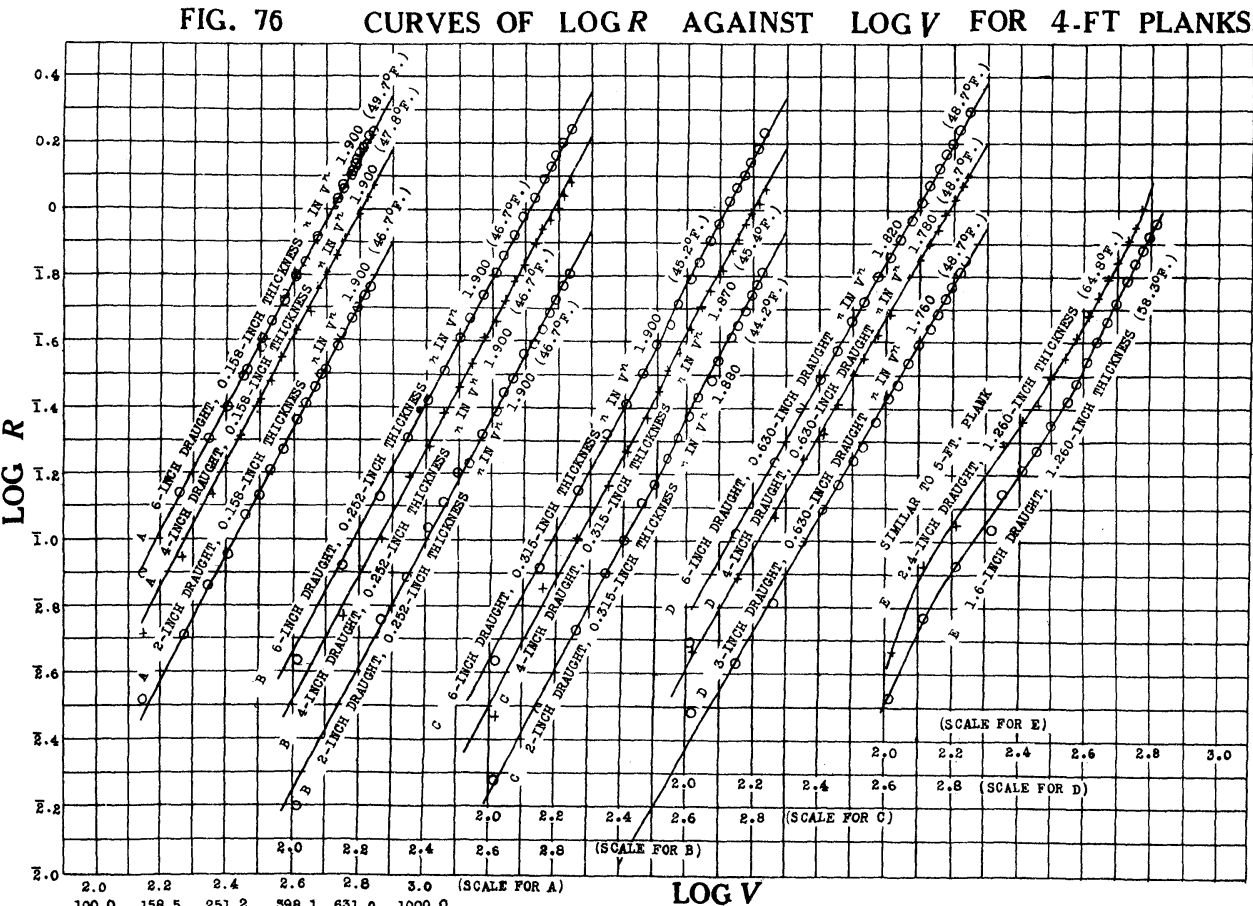

TH. Ta CURVES OF RESISTANCE AGANST 5-FT. PLANK AND 2-INCH DRAUGHT,

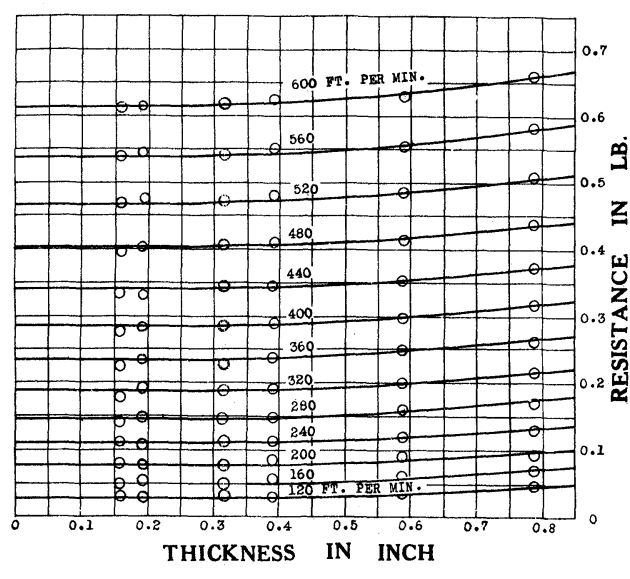

FIG. 73b CURVES OF RESISTANCE AGAINST

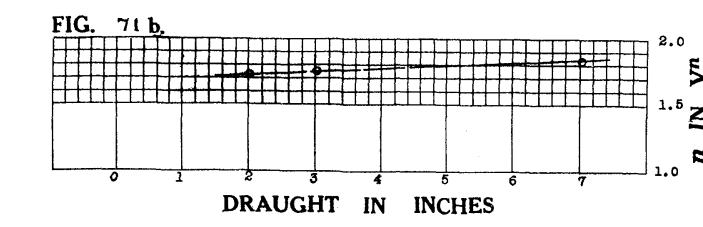

THICKNESS AT SEVERAL CONSTANT SPEEDS.

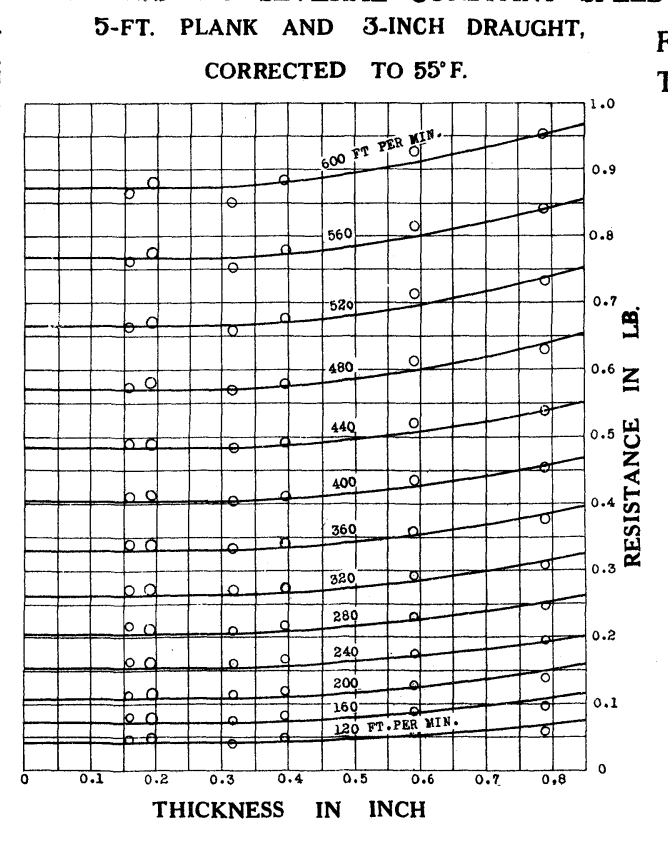
GG. 73C CURVES OF RESISTANCE AGAINST

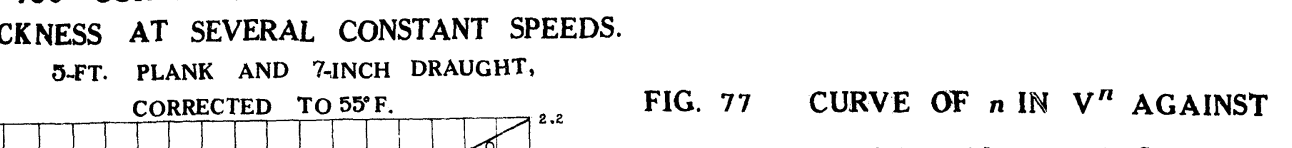

LENGTH OF PLATES.

FIG. 72 THICKNESS 3.150-INCH

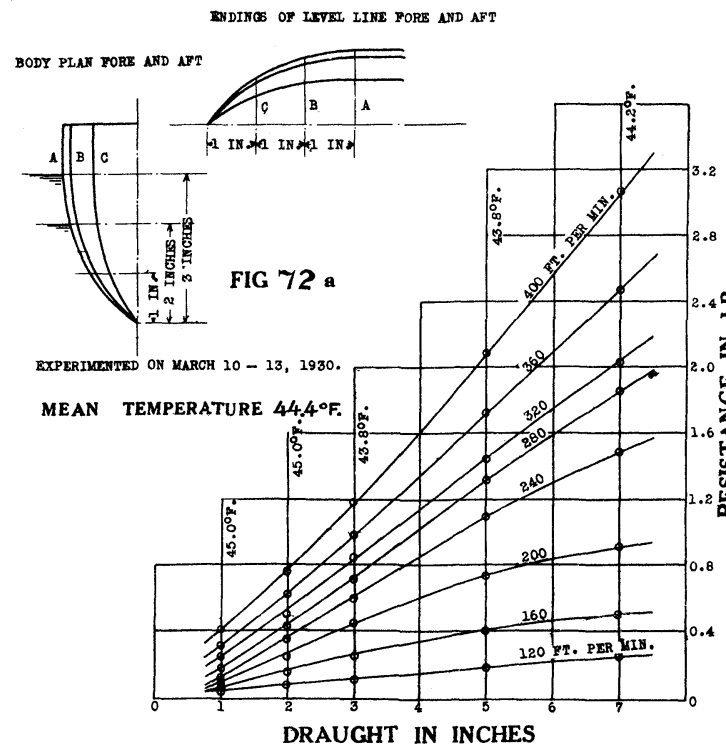

FIG. 75 CURVES OF LOWER EDGE EFFECT AGAINST THE THICKNESS OF PLANKS FOR 5.FT. PLANN,
AT SEVERAL CONSTANT SPEEDS.

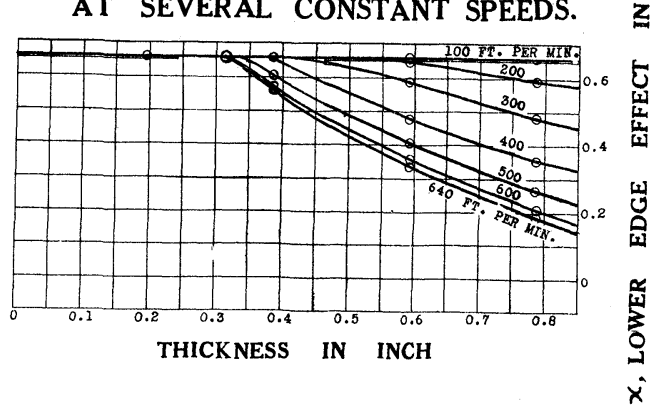

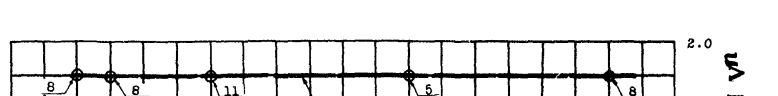

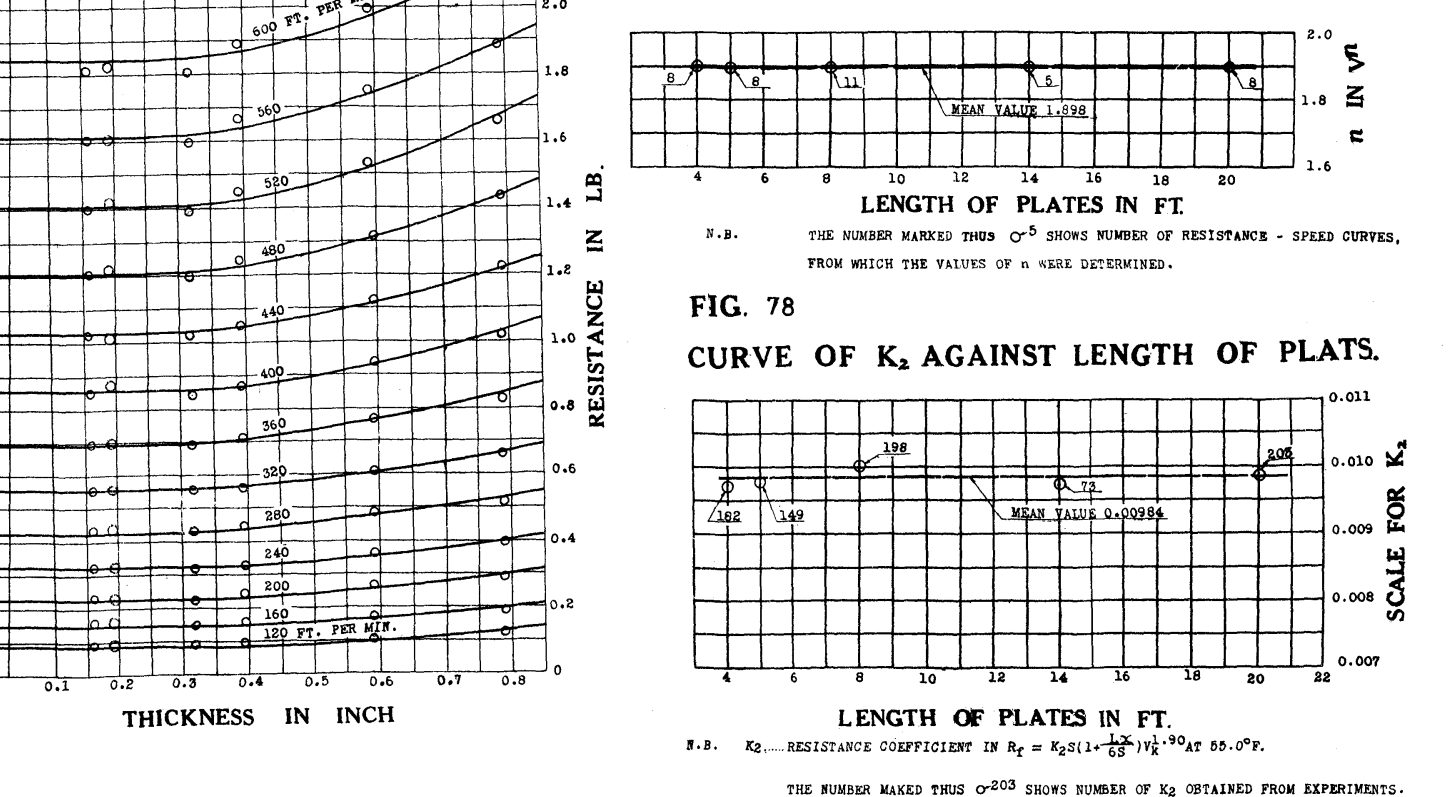

FIG. 74 CURVES OF $n$ IN $\mathrm{V}^{n}$ AGAINST THE

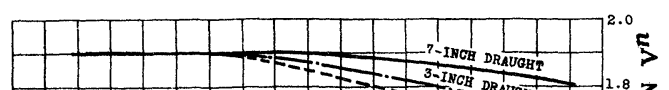

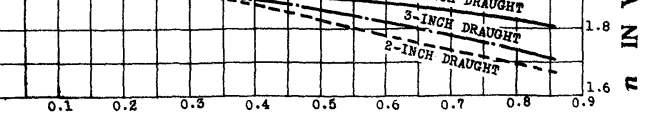

THCKNESS N INCH 
SEVERAL CONSTANT SPEEDS.

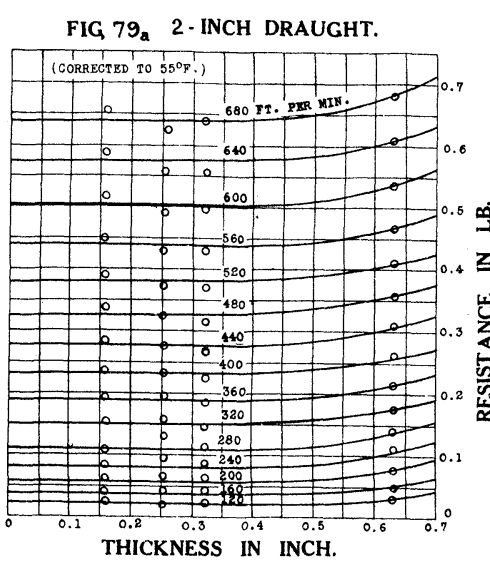

FIG. $79_{b}$ 4-INCH DRAUGHT.

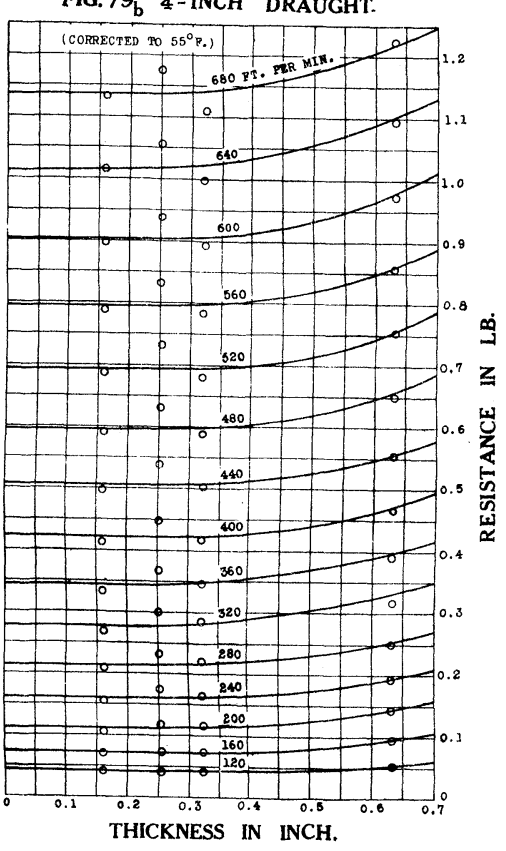

FIG. 80 RESISTANCE OF 8-FT. PLANKS AGAINST THICNESS OF PLANKS AT SEVERAL CONSTANT SPEEDS.

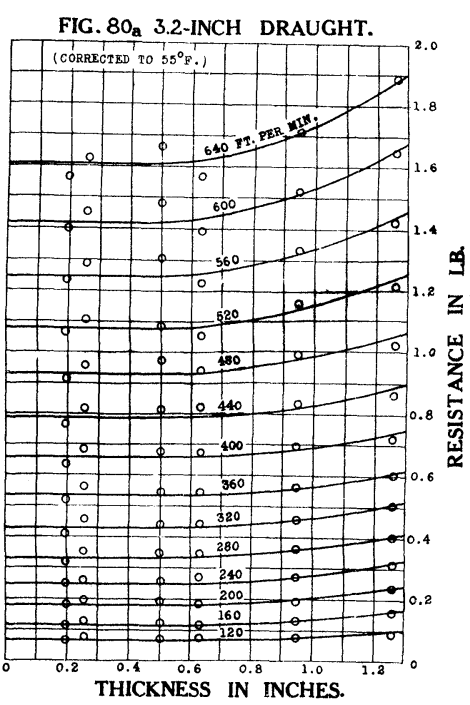

FIG. $80_{\mathrm{b}}$ 4.8-INCH DRAUGHT

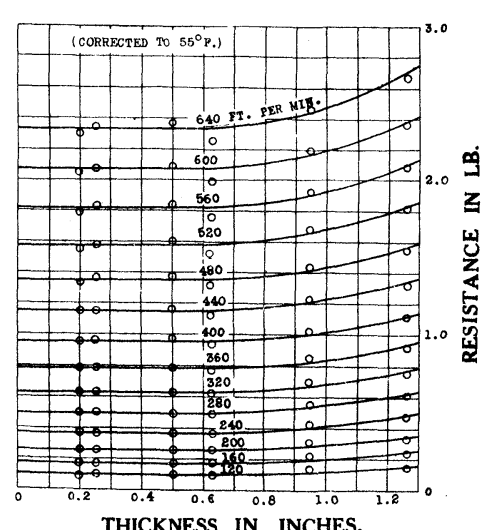

THICKNESS IN INCHES.

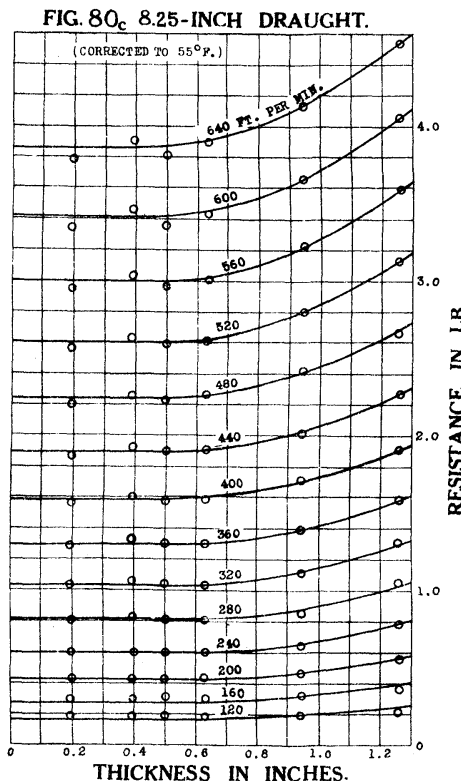

FIG. 8 I RESISTANCE OF I4 - FT. PLANKS

AGAINST THICKNESS OF PLANKS AT SEVERAL CONSTANT SPEEDS.

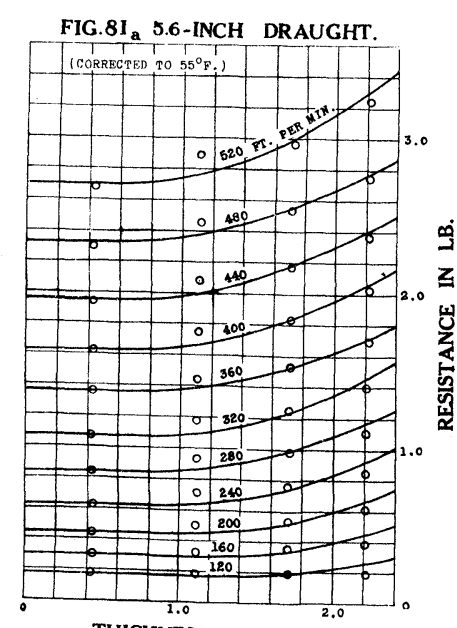

THICKNES IN INCH.0

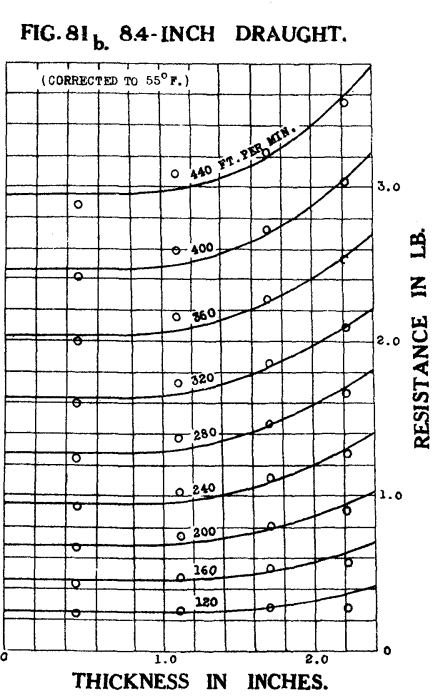

FIG. 82 RESISTANCE OF 20-FT. PLANKS AGAINST THICKNESS OF PLANKS AT SEVERAL CONSTANT SPEEDS.
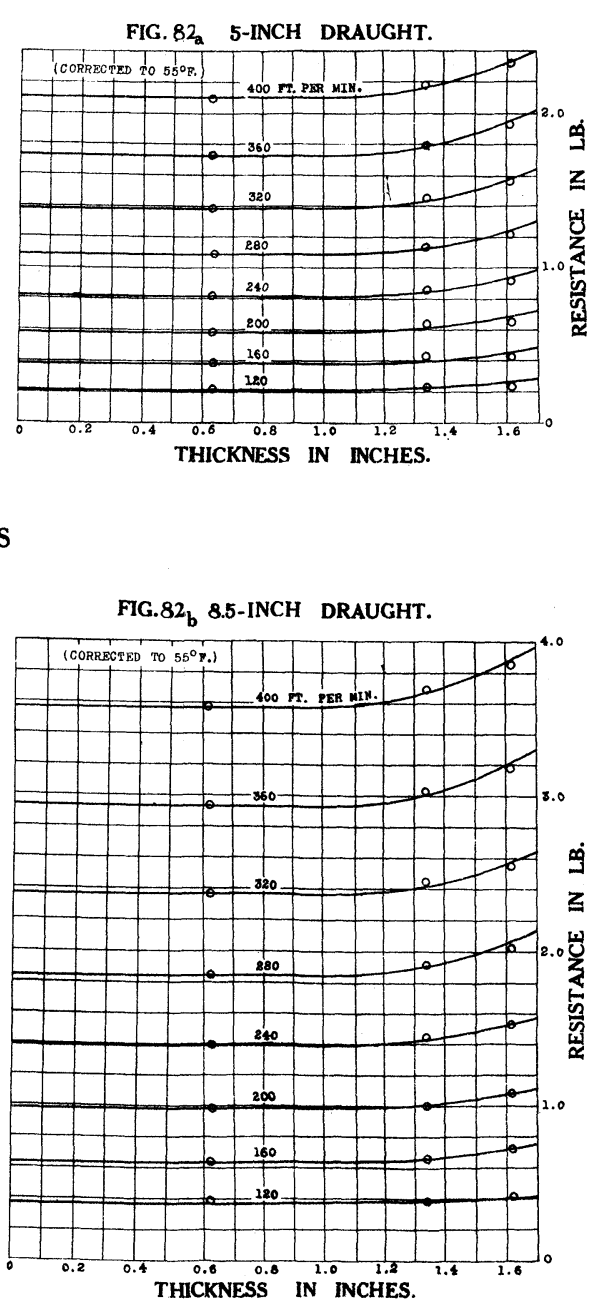

FIG.83 CURVES OF RESIDUARY RESISTANCE (ASSUMED) AGAINST SPEED FOR 2O-FT. PL.ANKS.

(DEDUCED FROM SHORTER PLANKS)

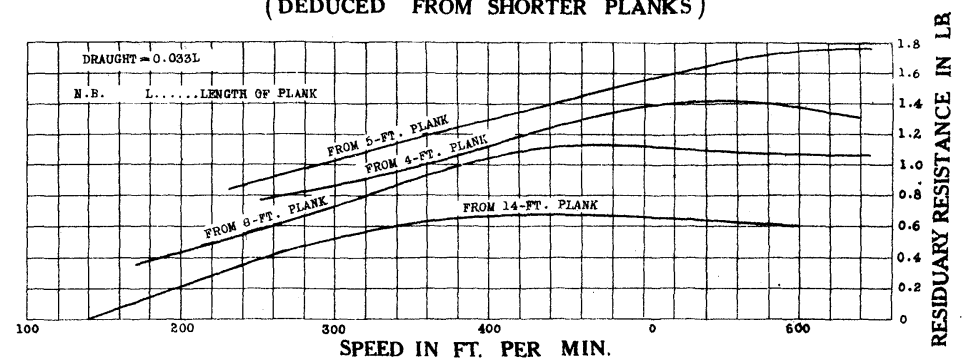

FIG. 84 CURVES OF RESIDUARY RESISTANCE (ASSUMED) AGAINST SPEED FOR 2O-FT. PLANKS.

(DEDUCED FROM SHORTER PLANKS)

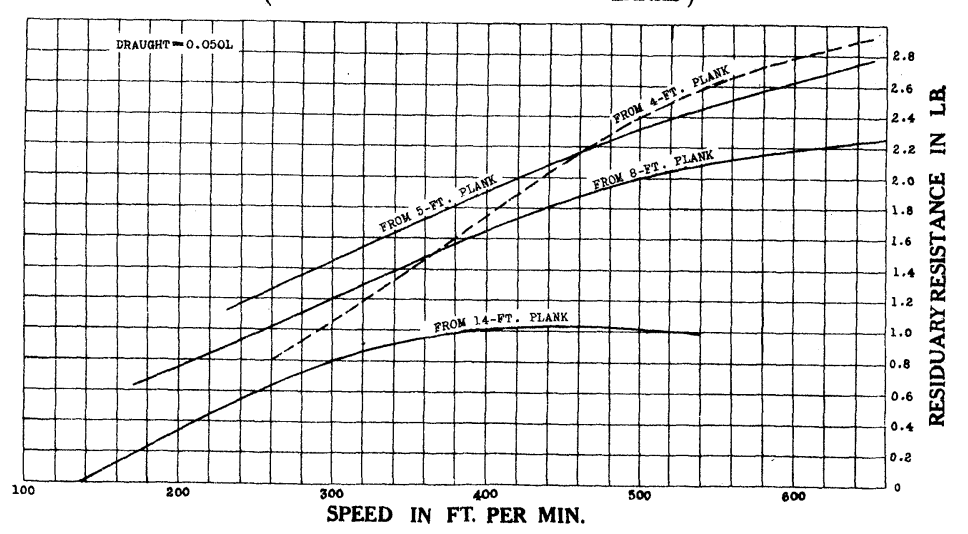

AT SEVERAL CONSTANT DRAUGHT/LENGTH

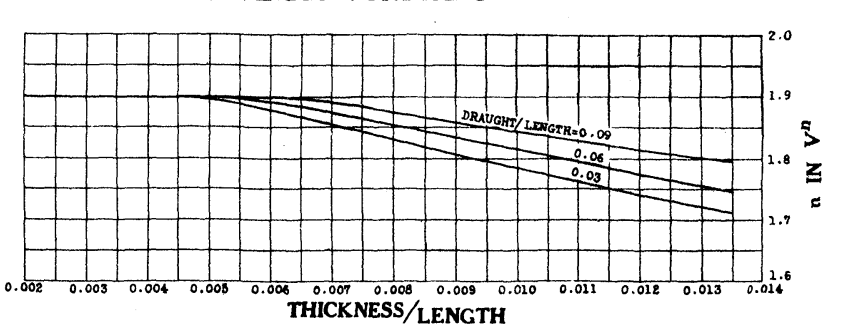


RESISTANCE AND COEFFICIENT OF SCALE EFFECT C FOR SHIP-MODELS.

FIG.88 CURVES OF EFFECT OF EXPERIMENTAL-TANK WALL ON THE RESISTANCE OF SHIP-MODELS.

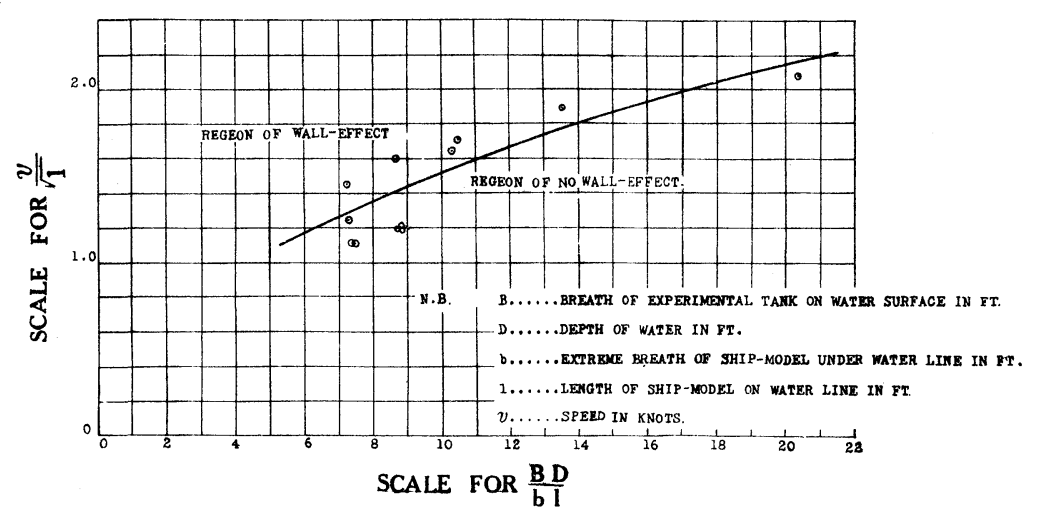

FIG.89 CURVES OF RESISTANCE AND $\frac{\lambda^{3}-\mathrm{R}}{S V_{k}^{1.90}}$ AGAINST SPEED.

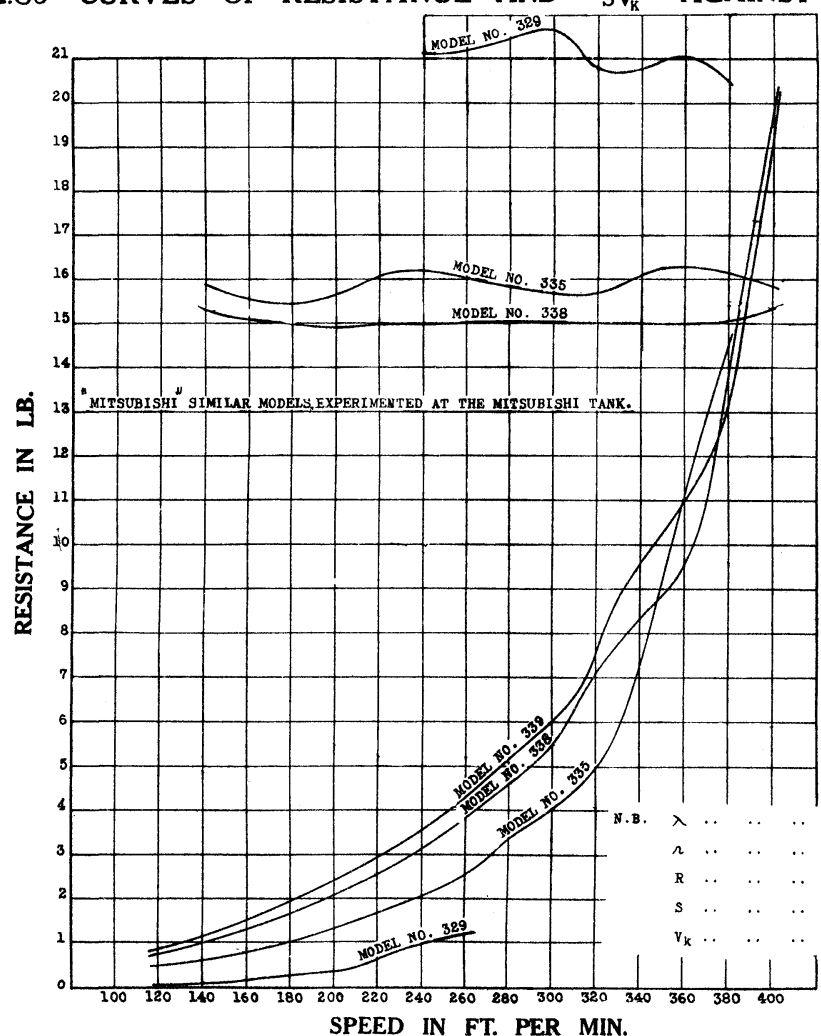

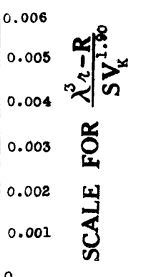

SPEED IN FT. PER MIN.

FIG.90 CURVES OF $\frac{\lambda^{3} r-R}{S_{\frac{1}{1}}^{1.90}}$ AND C AGAINST LENGTH OF SHIP-MODELS.

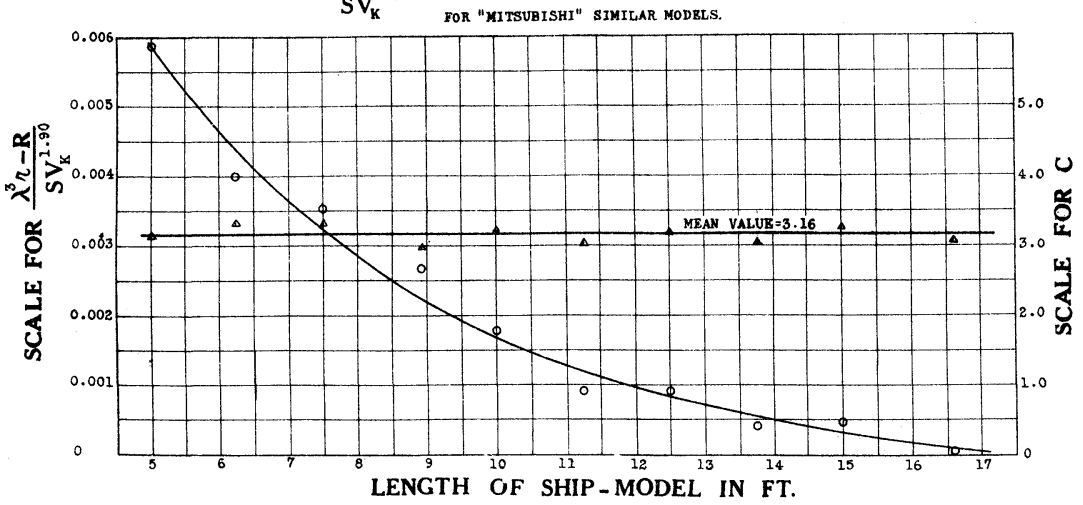

FIG.91 CURVES OF RESISTANCE AND $\frac{\lambda^{3} r-R}{S V_{x}^{1.90}}$ AGAINST SPEED.

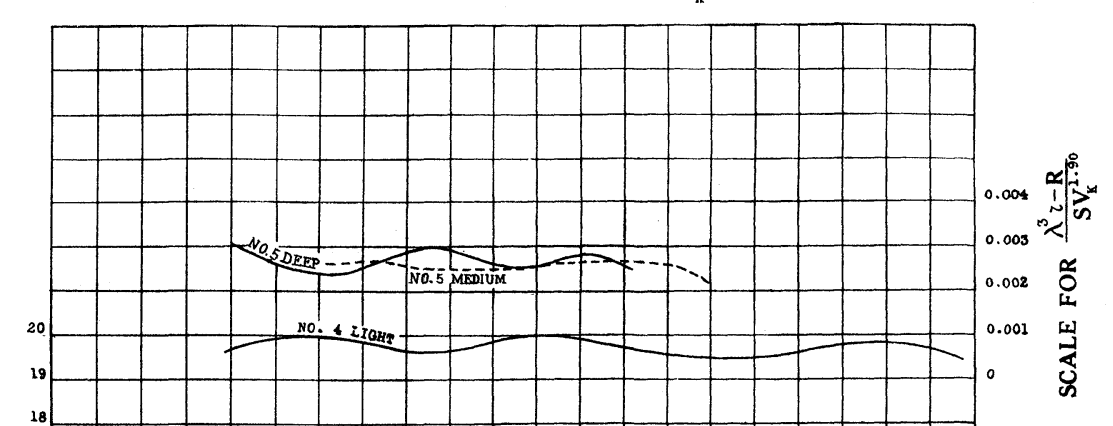

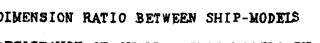

.

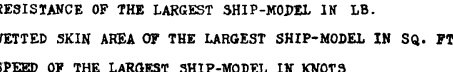

FIG.92 CURVESS OF $\frac{d}{L}$ AND $\frac{\Delta}{\left(\frac{L}{2}\right)^{3}}$ AGAINST C.

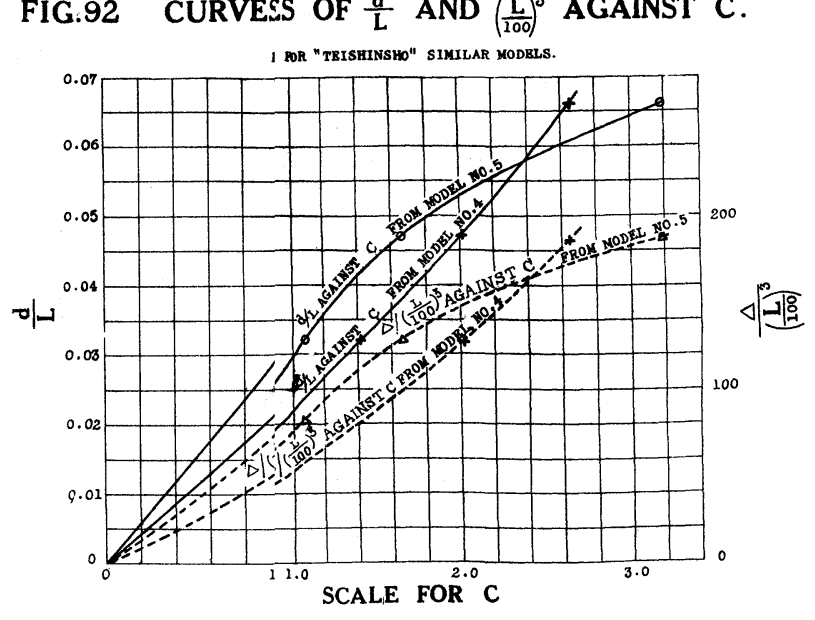

FIG.93 CURVES OF $\frac{d}{L}$ AND $\frac{\Delta}{\left(\frac{L}{100}\right)^{3}}$ AGAINST C.

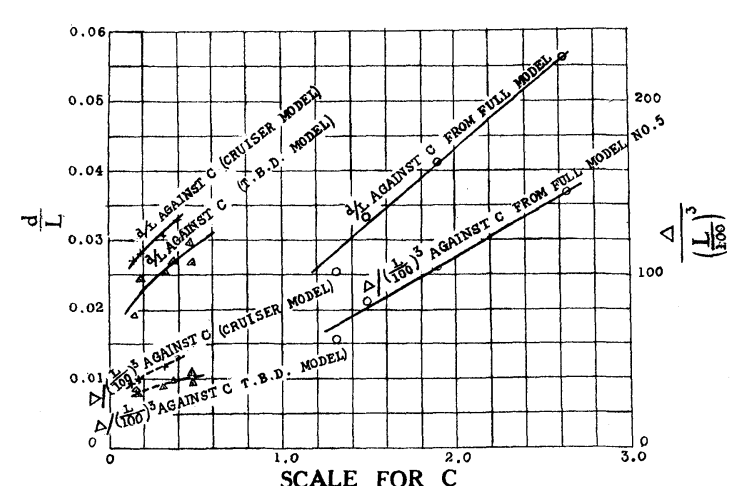

FIG.94 CURVES OF SCALE EFFECT C AGAINST $\frac{\Delta}{\left(\frac{L}{\mathrm{bo}}\right)^{3}}$

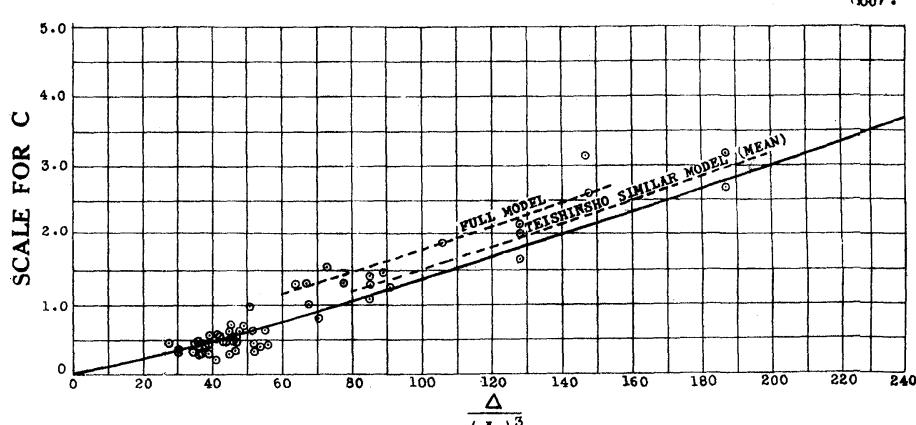

$\frac{\Delta}{\left(\frac{L}{100}\right)^{3}}$
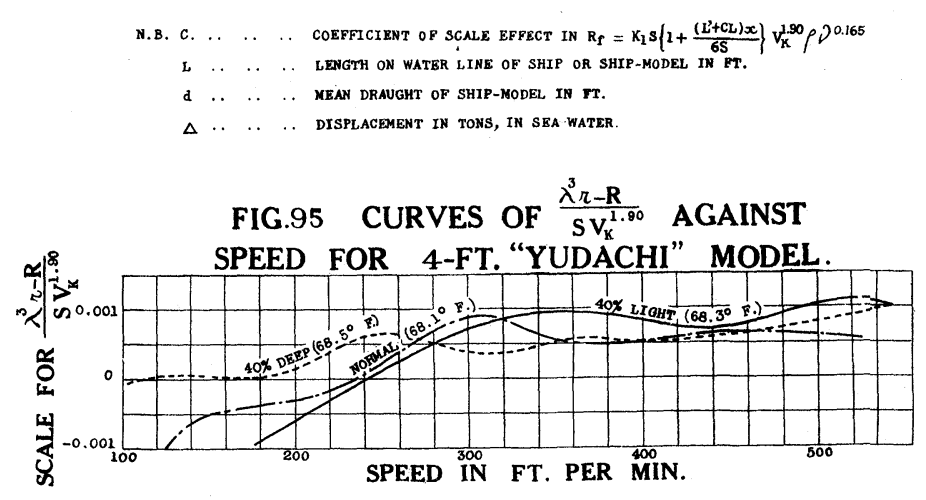

FIG. 96 CURVES OF $\frac{\lambda^{3} r-R}{S V_{K}^{1.50}}$ AGAINST

SPEED FOR 2-FT. "YUDACHI" MODEL.

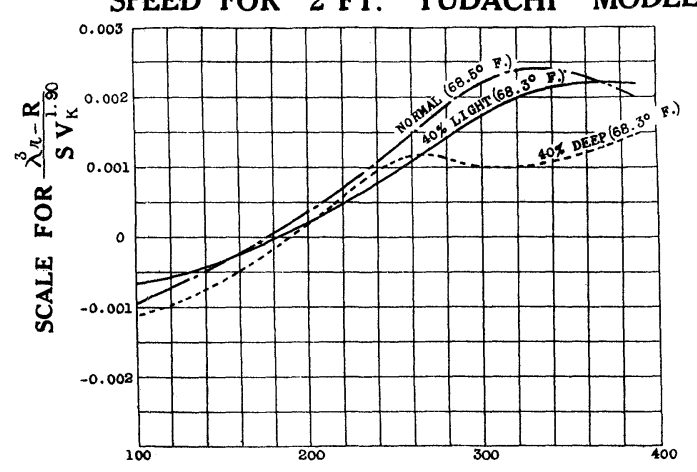

SPEED IN FT. PER MIN. 


\section{討論}

○會長(藤背範平君) 唯今の御講演に對し御意見又は御質問のある方は御述べを願ひます。

○出淵 巽君 此の第一論文及び第二論文で frictional resistance に關するあらゆる問題を研究し て發表されたのでありますが、特に frictional resistance が Reynolds law K follow せず、及 $K_{2}$ が length に independentであると云ふ事は私共に特に新しく感じられましたが、之につき今度の水 槽試驗會議で何か意見が出ませんでしたか。

○平賀 讓君 それは第一論文を知らなかつた爲に疑を持つて居たのは事實らしいけれども。同時 に實際に何とも言へなかつたのではないかとも思はれます。其時の discussion は手許にありますか ら。夫を御覽になれば良く分ります。實船の曳航實驗に就ては英國は 1925 年の committee で實驗 したいと云ひ、米國も Admiral Taylor は昨年の米國造船協會に於てそうしたいが、何れの國に於て も近い將來ではどうも不可能らしいといつて居ます。伊太利は General Rota が今回の會議に於て海 軍大臣に願つて居るので、其內に許可になるだらろといつて居ます。斯る情勢でありますから、日本 の論文を見て意外の感に打たれた人は少くなかつたららと思はれます。鬼に角第一論文を知らない ので何とも深くはいへなかつたのです。併し隨分いろいろの質問、討議がありました。或 tank の authority は自分の思つた通りだから意見も討論も無んといつて居りました。

○川原五郎君 大變に精密を實驗をなされ大に禆益される所あり厚く感謝の意を表する次第であり ます。此處には $70^{\prime}$ 一” 等の長い板に就てのはないのですか。

○平賀 讓君 夫は英國で讀んだ第二論文の方に在りますので、會長の御許しを得て此の討論のす んゲ後で一寸簡單に申上げる豫定です。

○川原五郎君 細から事を精密な御實驗で吾々を利益されて居りますが、 model で 200ー $0^{\prime \prime}$ 位で は Washington tank では index 1.854 を使ひ、Denny では 1.87 を使ひ、Froude は 1.94 で後 二者を本均すると 1.9 位になるが、長いるのが良く合ふといふ故此の formula は疑ふべくるないと 信じます。其樣を長的のを行つて實際に當嵌つて居るとの事で結構な事と思ひます。私も是非ての formula を使ひ度いと思ひます。未だ paper を拜見しただけで自分の data に合ふかしら妨が吾々 に此の formula を與へて下さつた事を感謝致します。

○本賀 讓君 今御話の simillar form の何かinformation 飞就て御持ちの data を拜見出來ま すれば非常に結構です。それから index に就ては英國での discussion で N.P.L. や英國海軍の Tank 關係者より高すぎるといはれましたが、此方には大小、澤山の實驗の結果でありますから、自信を持つ て居ります。只一言申上げますが、index を低くして抵抗一速度曲線の上の點郎ち高速力の邊を合は せますと下の方が合はなくなります。 speed の低ん所では total resistance より frictional resistance が大きくなる事があります。之は index が too small である事を示して居ります。夕立の場合には 
9 節まで一致して居ります。斯くの如く低速力に於て total resistance とfrictional resistance が合 ふ事は吾くにとつては。一つの proof と思ひます。鬼に角ての index が高すきると云ふ事は大分議 論がありました。

○山本武藏君 非常に內容の豐富な實驗をされ、其結果は又極めて重大であります。是は Londun で本賀博士が發表されたもの〉根本になるものでありまして Froude の實驗以來の劃期的のものであ り、非常に貴重なものであると考へます。此の全文を拜見しますと analysis が徹底的で極めて粘り 强くやつて居られ、哚く感激致した次第であります。今迄捉はれて居た $\nu$ と $V L$ との index て就て の考へは所謂型に嵌つて居つたものでありましたが、此の實驗結果は其方面で數步を進められたるの であります。本賀博士も最初は同一indexに出るものと思つて居られたらしく。p.137にも西る樣に 相當の點まで Reynolds' number に從つて行つたものか、行か好ものかと、迷つて居られた事が見え ますが、結果から見て極めて正確に全然從來の型を破られた事は誠に重大な成果を䶓らされたもので あります。私も之を二回程詳しく拜見しましたが、數年かかつて爲された御研究を、その位で彼是討 論するといふ事はとても出來ませんので只斯かる資料を拜見出來を事を個人的に誠に有難く感謝致し て居る次第であります。三三御何したい事がありますが(13)式中に X といふのがありますが、之は edge effect と書いてありますが、(13)式を一偏に計算しては $C$ を出せをせん。是は model を造り Xを出して(13)式にあて嵌めたものですか、如何ですか。それから、もら一つ御聞き致したい事は cut-up の effect が板の後方で特に著しいと云はれましたが、propeller の备る時は其作用の氶に edge effect は如何になりますか。それから draft でありますが tug boat の样に bow と stern で 可成り波立ち中央が極く hollow になつて居る樣な場合に靜水の時の draft を取ると心配の樣に思は れ又物足りね樣にも思はれますが如何ですか。

○本賀 讓君 唯今の初めの方の色々の御話に對しては感謝致します。御質間の model のXは model の edge effect が板のと同樣な事が證せられて居りますから、同じ長さの板のを用ひます。夫 で(13)式では similar models の實驗で $R$ と・のみを出せばよいので直に $C$ が計算されます。如 何なる draft を取るかは現在の所では still water の場合の wetted surface 及び draftを取るより 外ありません。それより水雷艇の如く走れば wave で length る draft も著しく變つて行くものでは lengthの變化の方が重大ではないかと思つて居ります。之れに就ては未だはつきりした考へはありま せんから、一切 still water に於ける length と draft を用みて居ります。 propeller のある場合の edge effect の變化は全く touch して居りませんから何とも言へません。

○蒲田利喜藏君 edge effectは Gebers のとは異ひますか。

○平賀 讓君 異ひがある積りです。吾ふのは edge がsharp の場合で、そうでない場合とは少々 異ひます。さらして吾くのは edge effect は板の長さに依りて變り郎ち長くなれば減つて行くと云ふ 處に特異性があるのであります。edge effect のみならず resistance が異ふのは外に原因があるらし 
レのですが、此の paper には touch して居りません。

○蒲田利喜藏君 私も其方面に興味をもつて居る爲に Gebersのを解折しましたが 1.9 位になりま した。Reynolds' no. を考へると厄介になつたので止めましたが 1.885 乃至 1.92 になつて居ります。 又 $R_{f}=K F V^{1.885} \rho \nu^{1}$ を得て居ります。重光博士の cylinder experiment の成績からも同じ值を得ま した。

○平賀 讓君 Gebers 實驗結果の index に就ては吾々もそら云ふのを得て居ります。Kempf で は 1.90 とはつきり出て居ります。theoryに合すために實驗の結果を可成 theoryに合はせるやうにや るの之、夫に捉はれないで自由に行るのとでは異なると思ひます。猶重光博士の eylinder experiment からは吾々の解析では殆ど $\nu^{0.165}$ に近いてとが本文中に述べてあります。

○渡邊惠弘君 摩擦抵抗に就ては近時流體力學の方から理論的に盛に研究されて居ますが摩擦抵抗 係數 $C_{f}$ が Reynolds 數 $R$ の函數である事は疑のない事柄で、唯之が如何なる函數であるかと云ふ 事は未だ理論的にはつきりして居らない樣であります。此の平賀先生の論文では此の函數を $\left[a+b R^{n}\right]$ 又は $b R^{n}$ の形に置いたのでは $R$ の廣い範圍の實驗結果を充分に現はし得ないとの事ですが、 $C_{f} に$ 對して所謂 Poteuzgesetz の理論的に成立するのは laminar flow の場合丈であつて turbulent flow の時は、從來は Blasius の $R<2.10^{5}$ の範園での管の中の水の流れに對する實驗を土臺にして Prandtl や Kármán が平板に對し $C_{f} \infty R^{-\frac{1}{5}}$ の結果を出して居ます。然し是は Blasius の實驗を基礎にして 計算した云はば semi-empirical とも云ふべき法則で $R$ の或 limit $\left(R>3.10^{6}\right)$ 以上では hold し得 ない事は認められて居ます。ですから一般に云へば $C_{f}$ が $R^{-m}$ の形を持つと云ふ事は絕對に成立す る事ではなく、若し强へて此の形に置くならば此の $m$ は $R$ の函數之見なければなりません。Kármán は其論文 (Mechanische Ahnlichkeit und Turbulenz, Proe, 3rd. Int. Cong. Appl. Mech.Vol. I.) で $C_{f}$ は Poteuzgesetz で現はすべき性質のものでなく、若し左樣すれば $R$ が增せば $m$ は減少する性質 のものだと云つて居ります。左樣ですから、此の非常に廣沉にして且つ用意極めて周到なる實驗の結 果は、理論の發展に光明を與へ且つ指導する之云ふ意味から云つても單に從來の $\left[a+b R^{-n}\right]$ 又は $\left[b R^{-n}\right]$ の函數の型ときめず，もつと一般的の $R$ の函數と見て analyse されて $R$ の大き的處に於け る $C_{f}$ と $R$ との關係に對する實驗的の結論を與へて下されたなら、實際家のみなら亦理論家に對し ても益する處尠からざるものと信じられます。

○本賀 讓君 渡邊君は摩擦抵抗係數が Reynolds 數の函數であることは疑のない事柄であると言 はれますが、是は該係數が $V, L$ 及び $\nu$ のの函數であると云ふ假定の下に言はれ得るととであり。 又 nature of surface が常に similar でなくてはいけないのであつて、是が一定であつた場合の法 則と云ふのは全く未知であります。先程山本博士が御氣附きになつて申されました樣に、私も初めは 該係數が Reynolds 數の函數となることを期待したのでありましたが、結果はさうならなかつたのみ ならす、 edge effect などの現象の分るに件つて益々疑が深くなつたのであります。又渡邊君は私が 
$\left[a+b R^{n}\right]$ 又は $\left[b R^{n}\right]$ なる型のみに就て考へたやうに言はれますが $R /\left(\rho S V^{2}\right)$ を $V L / \nu$ base に plot し て種々調べて見たてとは郎ち廣い意味での Reynolds 數の函數として取扱つて見たのであつて、吾々 は一枚の板の精密なる temperature-effect experiment の結果から見ても、又短い板から長い板迄 similar form のものは元よりのてと（但し nature of surface は常に一定である)、同じ長さの板な れば種々に draft を變更して極めて多數の實驗を行つを其結果から見ても抵抗係數を Reynolds 數の 函數と認むる譯には行きませんでした。それよりる吾くは edge effeet が長き板程減少するてと確 め、此 edge effect に基く抵抗をさへ除去すれば、短い板も長い板も一定の溫度之速度に於ては Resistance per unit area は一定であると云ふ極めて簡明な結果に到達して新しい formula を得た ので、而かも私の偷敦に於て讀んだ處の論文に詳述してあるやうに此の結果を板船、驅逐艦及び曳船 の實船曳航實驗に依つて確的得たのであります。從つて Reynolds' number の如何なる意味での functionに依りても此の結果は現はすことはむづかしい事となつて居るのであつて、寧ろ是が渡邊君 の最後に御希望になつを $C_{f}$ と $R$ との關係に對する實驗的結論であると御承知下さつて宜しからう かと考认ます。

勿論私の formula は本文中に明記してありますやうに、飽迄所謂 inductive formula であつて、 dimension も合つて居りません。郎ち純理論的に不完全であります。私は實驗の示した處のものを何 ものにも捉はれず最も忠實に發表したのでありますから、渡邊君其他。其道の學者が捉はれざる理論 的研究を此の實驗の結果汇就て行つて下さることを切望するのであります。猶其一つの方法として私 の suggest し度レのは何よりも edge effectなるもの」理論的解決であります。

○八代 準君 唯今實驗の結果から見ると、摩擦抵抗は Reynolds 數に從つて變化しない樣に思は れるとの平賀博士の御話に對し、渡邊博士の御討論がありましたが、私は船の抵抗に對し Reynolds， 數を criterion として用ふるととの可否に就て疑問を有つて居るのであります。佛國の學者の或部の 人ネ、例へば M. Escande の如きは、Reynolds の法則は一定の壓力下に於て free surface を有せ ず動く流體、師ち管の中を水が流れる樣な場合によく當嵌り、夫等の實驗成績が基礎となつて此法 則が出來て居り、Reynolds は linear dimension として流れに直角の方向にある管の直徑を探つて居 るが、船の場合は水が free surface を持つて居り、且つ水の流れ方も種及な點で管の場合々違ふか ら、船の抵抗は Reynolds 法則に從はないと云ふて居る樣に記憶します。それで私は、平賀博士の實 驗の結果を、既製の理論に捕はれずに、有の儘に見てょく考察するととが必要であると考へるのであ ります。

○平賀 讓君 八代君の唯今御引用になつた Reynolds 數を板又は船に應用するととに就ての意見 はたんへん面白く思ひます。又八代君の言はれましたやうに、充分な注意を以て行はれた實驗は何も のにも捉はれずに是を考察すると云ふととの必要は全然同感でありまして、私も亦其積りで行つたの であります。 
○會長(藤嶋範平君) も5他に御發言の方はありませんか。

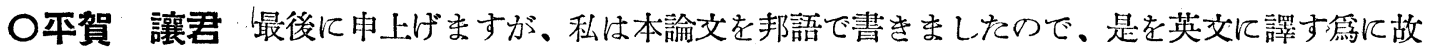
山本長方博士几御賴みしたのでありますが、博士は御快售下さつて、決して普通の英譯ではなく、私 の述べんと欲する處のものを最も善く英文で現はして下さつたのであります。第一論文は全部終了し 第二論文も殆ど終了した時に博士は御逝去になつたのです。兹に謹んで故人に對して厚く御僼申上げ る次第であります。

○會長(藤嶋範本君) 他仵發言がなければ此の論文のdiscussionは之で打切ります。向 London で發表された第二論文も此の際其梗概を示して戴く事が雄る有益と思しますから、引䊧き本賀博士に 御話して戴き度いと思ひます。

○本賀 讓君 會長の御許を得て極く簡單儿御話し申上げます。

(本賀博士の說明は之を省略し、論文全文を本論文の次に揭載する事にした。）

○會長 (藤嶋範平君)，唯今の第二の paper に關する御話に對し御質問又は御意見のある方もあ りませらが、此の廣沉なる paper は何等かの方法で造船協會員諸君に御覽に入れたいと考へて居り ますから、其時更めて御意見の發表を願ふとして、今日は討論を止めます。

此の際簡單に一言御禮を申上げます。平賀博士は海軍技術研究所飞居られた時分所員各位之數年間 に亘り研究されました其結果を今日御發表になりました。夫が第一の paper で、第二は英國の造船 協會に於て日本の代表として御講演てなつたものであります。Floude が Greyhound で實驗されて より六十年後に平賀博士が此の論文を發表されましたのは實に epoch-making の paper 之棌すべき であります。英國て講演された時、Greenwich 御在學當時の先生たるSir James Henderson 及び Sir Westeott Abell 兩氏がロを極めて賞讃し、又歐米各國の tank の authority が爭ふて此の論交 を批評せられたのであります。之はこの paper の立派なる事を裹書するものであります。然も是等 の人《は第一の paper は見市、第二の paperを短時間化研究された丈であります。本日の講演が全

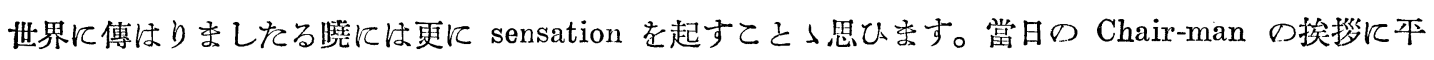

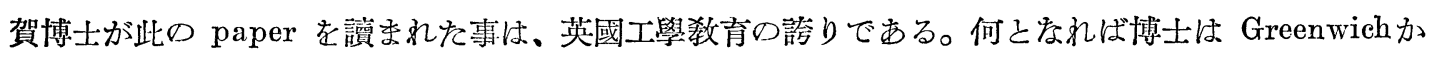
ら出た學者であるからである。又日本に於て之を發表せ秃して態及英國倈り我協會に於て讀まれた 事は英國造船協會の誇りであると云ふて居られます。之を見ても平賀博士の paper が如何几受取ら

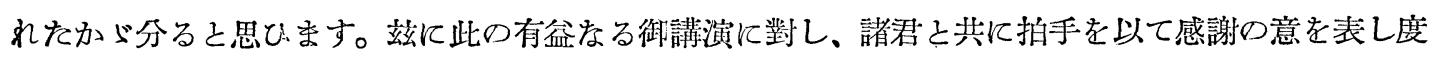
いと思ひます。(一同拍手)

追記

○渡邊惠弘君 私の討論の後飞行はれた八代博士の御討論は私の言つた事て對する御討論の樣です から、是に對する私の意見を述べさせて頂ければ幸に存じます。私の言つた事は凡て平板の摩擦抵抗 
に關する事で八代博士の御議論は船のそれですから少し事柄が違します。次に討論の討論の討論を許 して下さるならば、八代博士の御意見では船の摩擦抵抗は Reynolds の法則々從はぬ(是は $C_{f}$ は $R$ の函數でないと理解してよいと思はれますが）のがはんとうだと言はれて居る樣ですが、是は寧ろ $R$ だけの函數ではないと云ふ方が正しいのではないかと思はれます。郎ち船の場合には波による水の波 動運動が摩擦抵抗に影響を與へ、此の外 dynamical pressure による trim の變化なども影響を與へ る事が考へられます。是に對する相似則はFroude の法則に依りますから、從つて $C_{f}$ は $R$ だけで なく $\frac{v}{\sqrt{g l}}$ なる Froude の const. のF の函數であり得て即ち $C_{f}(R . F)$ と見るべきだらうと思はれま す。Reynolds の法則は Reynolds が實驗から出したものでなく、唯實驗して見て氣がついた事で、 Reynolds の實驗とは全く獨立して存在する法則ですから、是が成立しないと云ふ事は現在一般に取 扱はれて居る粘牲流體て對する Navier-Stokes の運動方程式を否定する事と同じ事となります。 France の學者の言つて居ると云方事も上の樣な意味に取るべきものだらうと考へられます。何波の $C_{f}$ に對する影響の一つとして波のための表面積の變化を考へた摩擦抵抗を Wigley (T.I.N.A. 1927) が計算して居ますが、是による影響は極めて僅少であると云つて居る樣です。 